US Army Corps

of Engineers

Engineer Research and

Development Center

Aquatic Plant Control Research Program

\title{
A Simulation Model for Growth of the Submersed Aquatic Macrophyte Eurasian Watermilfoil (Myriophyllum spicatum L.)
}

by Elly P. H. Best, William A. Boyd

Approved For Public Release; Distribution Is Unlimited

Prepared for Headquarters, U.S. Army Corps of Engineers

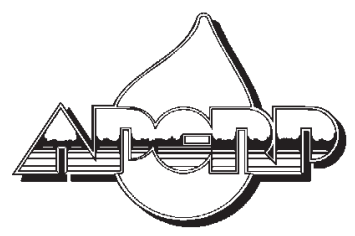


The contents of this report are not to be used for advertising, publication, or promotional purposes. Citation of trade names does not constitute an official endorsement or approval of the use of such commercial products.

The findings of this report are not to be construed as an official Department of the Army position, unless so designated by other authorized documents. 


\section{A Simulation Model for Growth of the Submersed Aquatic Macrophyte Eurasian Watermilfoil (Myriophyllum spicatum L.)}

by Elly P. H. Best, William A. Boyd

U.S. Army Engineer Research and Development Center Waterways Experiment Station 3909 Halls Ferry Road

Vicksburg, MS 39180-6199

Final report

Approved for public release; distribution is unlimited 


\section{Engineer Research and Development Center Cataloging-in-Publication Data}

Best, Elly P.H.

A simulation model for growth of the submersed aquatic macrophyte Eurasian watermilfoil (Myriophyllum spicatum L.) / by Elly P.H. Best, William A. Boyd ; prepared for U.S. Army Corps of Engineers.

111 p. : ill. ; $28 \mathrm{~cm}$. - (Technical report ; A-99-3)

Includes bibliographic references.

1. Growth (Plants) - Computer simulation. 2. Plant biomass - Computer simulation. 3. Eurasian watermilfoil - Computer simulation. 4. MILFO (Computer programs) I. Boyd, William A. II. United States. Army. Corps of Engineers. III. U.S. Army Engineer Research and Development Center. IV. Aquatic Plant Control Research Program (U.S. Army Engineer Research and Development Center) V. Title. VI. Series: Technical report A ; 99-3.

TA7 W34 no.A-99-3 


\section{Contents}

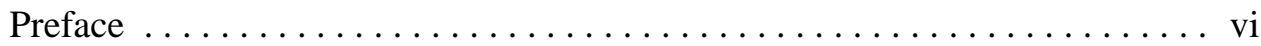

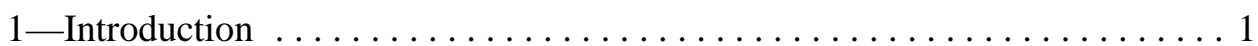

General ..............................

Distribution of Eurasian Watermilfoil within the United States $\ldots . \ldots \ldots 1$

2-MILFO: Description of Model $\ldots \ldots \ldots \ldots \ldots \ldots \ldots \ldots \ldots \ldots \ldots \ldots \ldots$

Modeling Concepts . . .......................... 3

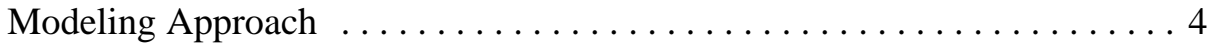

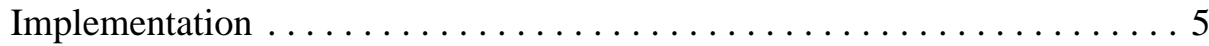

Model Features . .......................... 5

3-Model Processes $\ldots \ldots \ldots \ldots \ldots \ldots \ldots \ldots \ldots \ldots \ldots \ldots \ldots$

Morphology, Phenological Cycle, and Development .......... 8

Maximum Biomass and Plant Density . . . . . . . . . . . . 13

Wintering and Sprouting of Rhizomes/Root Crowns

and Growth of Sprouts to Water Surface . . . . . . . . . . . 13

Light, Photosynthesis, Maintenance, Growth, and Assimilate

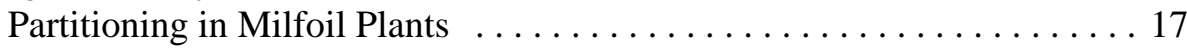

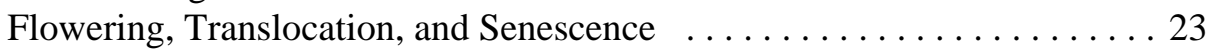

Choice of Parameter Values . . . . . . . . . . . . . . . . . . . . . 27

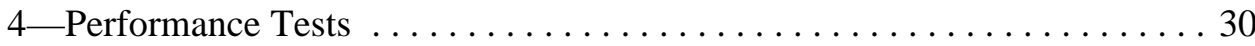

Simulated and Measured Behavior of a Milfoil Community

in Lake Wingra, Wisconsin . . . . . . . . . . . . . . . . 30

Simulated and Measured Behavior of a Milfoil Community

at Other Latitudes . . . . . . . . . . . . . . . . . . . . 36

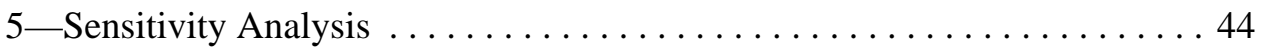

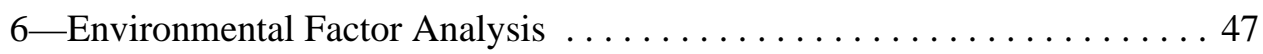

Climate ............................... 47

Light-Reflection Coefficient at Water Surface . . . . . . . . . . 47

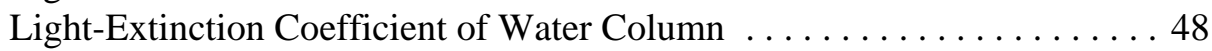

Water Depth .......................... 49

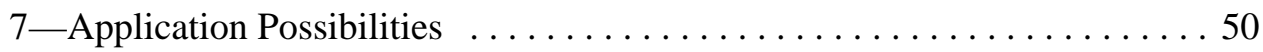




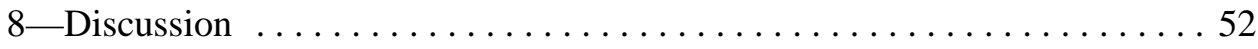

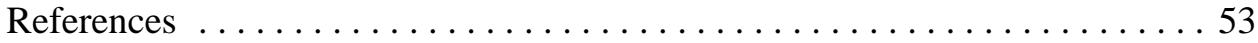

Appendix A: Model Listing $\ldots \ldots \ldots \ldots \ldots \ldots \ldots \ldots \ldots \ldots \ldots \ldots \ldots \ldots$

Appendix B: Variable Listing $\ldots \ldots \ldots \ldots \ldots \ldots \ldots \ldots \ldots \ldots \ldots \ldots \ldots$

Appendix C: Manipulation of Literature Data Used

for the Model Equations $\ldots \ldots \ldots \ldots \ldots \ldots \ldots \ldots \ldots \ldots \ldots$

SF 298

\section{List of Figures}

Figure 1. Relational diagram of MILFO and its subroutines in combination with FSE shell $\ldots \ldots \ldots \ldots \ldots \ldots \ldots$

Figure 2. Relational diagram illustrating wintering and sprouting of rhizomes/root crowns in milfoil . . . . . . . . . . . . 16

Figure 3. Relational diagram illustrating photosynthesis, respiration, and biomass formation in milfoil ............... 24

Figure 4. Relational diagram illustrating translocation and senescence following anthesis in milfoil $\ldots \ldots \ldots \ldots \ldots \ldots \ldots \ldots$

Figure 5. Simulated biomass of shoots, roots, and rhizomes/root crowns and measured shoot biomass of a milfoil community in Lake Wingra, Wisconsin . . . . . . . . . 31

Figure 6. Simulated behavior of carbohydrate flow through plant compartments ...................... 32

Figure 7. Simulated rates of daily net assimilation and maintenance respiration of a milfoil community in Lake Wingra, Wisconsin .............................. 33

Figure 8. Simulated biomass with assimilate requirement for growth value nominal or as suggested for submersed aquatic vegetation and measured shoot biomass of a milfoil community in Lake Wingra, Wisconsin . . . . . . . . . . . . 34

Figure 9. Simulated biomass with (A) and without (B) initial plant biomass and measured $(\mathrm{C})$ shoot biomass of a milfoil community in Lake Wingra, Wisconsin . . . . . . . . . . 35

Figure 10. Simulated photosynthetic rates of a milfoil community in Lake Wingra, Wisconsin, with water or air

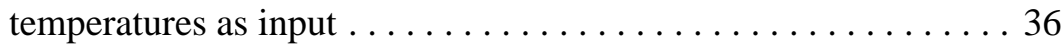


Figure 11. Simulated biomass with (A) water temperatures of a different year, 1970, or (B) air temperatures of the same year, 1972, as inputs and (C) measured shoot biomass, 1972, of a milfoil community in Lake Wingra, Wisconsin . . . . . . . . . . . . . 37

Figure 12. Simulated biomass of shoots, roots, and rhizomes/root crowns and measured shoot biomass of a milfoil community in Lake Guntersville, Alabama

Figure 13. Simulated biomass of shoots, roots, and rhizomes/root crowns of a milfoil community in Lake Guntersville, Alabama, composed of two or three plant cohorts and using various initial biomass values ...

Figure 14. Simulated biomass of shoots, roots, and rhizomes/root crowns and measured shoot biomass of a milfoil community in Kashmir lakes, India

Figure 15. Simulated biomass of a milfoil community at various latitudes

\section{List of Tables}

Table 1. Relationship Between Development Phase of Milfoil, Day of Year, and $3{ }^{\circ} \mathrm{C}$ Day-Degree Sum for a Temperate Climate. .......................... 11

Table 2. Relationship Between Development Phase of Milfoil, Day of Year, and $3{ }^{\circ} \mathrm{C}$ Day-Degree Sum for a Tropical Climate .......................... 12

Table 3. Parameter Values Used in MILFO . . . . . . . . . . . . 28

Table 4. Relative Sensitivity of Two Model Variables to Deviations in Parameter Values from Their Nominal Values ... . . . . . . 46

Table 5. Environmental Factor Analysis, Expressed as Relative Sensitivity of Two Model Variables to Deviations in Parameter Values from Their Nominal Values . . . . . . . . . 48

Table 6. Effects of Mechanical Harvesting Date and Depth on Plant and Rhizome/Root Crown Biomass 50 


\section{Preface}

The work reported herein was sponsored by the Aquatic Plant Control Research Program (APCRP), Work Unit 32440. The APCRP is sponsored by Headquarters, U.S. Army Corps of Engineers (HQUSACE), and is assigned to the U.S. Army Engineer Research and Development Center (ERDC) under the purview of the Environmental Laboratory (EL). Funding was provided under Department of Army Appropriation Number 96X3122, Construction General. The APCRP is managed under the Center for Aquatic Plant Research and Technology (CAPRT), Dr. John W. Barko, Director. Mr. Robert C. Gunkel, Jr., was Assistant Director, CAPRT. Technical Monitor during this study was Mr. Timothy Toplisek, HQUSACE.

Principal Investigator for this work unit was Mr. R. M. Stewart, Ecosystem Processes and Effects Branch (EPEB), Environmental Processes and Effects Division (EPED), EL, ERDC. The work described herein was performed by Dr. Elly P. H. Best, Fate and Effects Branch, EPED, with programming assistance from Mr. William A. Boyd, EPEB. Ms. Anne B. Stewart, AScI Corporation, assisted with the graphics. Dr. Best and Mr. Boyd prepared this report. Dr. F. G. Wortelboer (National Institute for Environmental Research, De Bilt, The Netherlands) provided an external technical review. The report was reviewed internally by Drs. John D. Madsen and Robert Kennedy, EPEB.

This investigation was performed under the general supervision of Dr. Richard E. Price, Chief, EPED, and Dr. John W. Keeley, Acting Director, EL.

At the time of publication of this report, Dr. Lewis E. Link was Acting Director of ERDC, and COL Robin R. Cababa, EN, was Commander. 
This report should be cited as follows:

Best, E. P. H., and Boyd, W. A. (1999). "A simulation model for growth of the submersed aquatic macrophyte Eurasian watermilfoil (Myriophyllum spicatum L.)," Technical Report A-99-3, U.S. Army Engineer Research and Development Center, Vicksburg, MS.

The contents of this report are not to be used for advertising, publication, or promotional purposes. Citation of trade names does not constitute an official endorsement or approval of the use of such commercial products. 


\section{Introduction}

\section{General}

The degree to which aquatic macrophytes influence the ecosystem is proportional to plant mass and depends on plant species and physicochemical factors. Therefore, predictions of the environmental impact of management measures concerning aquatic communities should be based on accurate estimates of (a) plant species and mass and its pertinent physiological properties, (b) the contribution of plants to the various food chains, and (c) the contribution of the decay of plants to biogeochemical cycling and oxygen regime. A simulation model for metabolism and growth of aquatic community types may serve as a useful tool in this respect.

Although the number of simulation models for growth of monotypic, submersed macrophyte communities is increasing (e.g., Titus et al. 1975; Best 1981; Collins and Wlosinski 1985; Best and Jacobs 1990; Hootsmans 1991, 1994; Scheffer, Bakema, and Wortelboer 1993; Best and Boyd 1996), it is still relatively low compared with that for terrestrial vegetation. The current model has been developed because none of the existing models were suitable to simulate the behavior of a monotypic milfoil community under various environmental and climatological conditions over a period ranging from season to several years.

\section{Distribution of Eurasian Watermilfoil within the United States}

The submersed, rooted aquatic macrophyte Myriophyllum spicatum L. or Eurasian watermilfoil belongs to the dicotyledonous family Haloragaceae. It has the ability to survive unfavorable environmental conditions and has been demonstrated to outcompete many other submersed aquatic plant species in temperate, subtropical, and tropical areas. This species has consequently a very large distributional area. It may be considered as the most aggressive member of a circumboreal complex of closely related taxa (Patten 1954). A problem in discussing the distribution and rapid spread of Eurasian watermilfoil is that this plant species is morphologically very similar to the native North American 
milfoil variously named Myriophyllum exalbescens Fern., M. spicatum var. exalbescens (Fern.), and M. spicatum subsp.exalbescens (Fern.) Hult. The taxonomic distinction probably has not been made in all cases when these two species have been discussed in literature. Hereafter, Eurasian watermilfoil will be referred to simply as milfoil.

Milfoil is a native of Eurasia. It has been present in the United States since 1948 (Couch and Nelson 1985). This species was not considered a weed until the late 1950s. Since that time, it has spread from the east to the west coast in both the United States and Canada (Reed 1977; Aiken, Newroth, and Wile 1979), and it has been documented in 44 of the States and 3 Canadian provinces (Engel 1993). Spreading of species over large distances was partly related to aquarium and aquatic nursery trade (Reed 1977). Short-distance dispersal probably occurred by transport of plant fragments between lakes on boats or trailers (Scales and Bryan 1979). The explosive growth appears to follow major environmental disruptions (Nichols and Shaw 1986). For example, the Chesapeake Bay population increased only in the 1950s and early 1960s (Allen 1973; Bayley et al. 1978) after hurricanes hit the area repeatedly causing temporarily increased salinity, sedimentation, and inflow of nonpoint source pollutants. Increased milfoil growth in Cayuga Lake, New York, and Lake Mendota and Lilly Lake, Wisconsin, is attributed to major natural or human caused disruption (Lind and Cottam 1969; Oglesby et al. 1976; Nichols 1984). Dramatic population fluctuations appear to be characteristic, since they have been reported not only in the native Eurasian range of milfoil (LundegardhEricson 1972; Jeschke and Muther 1978) but also in the Chesapeake Bay area and in Lake Wingra. In the Chesapeake Bay area, milfoil declined first in the most recently colonized areas rather than in the original epicenters of growth (Bayley et al. 1978), as such suggesting a pattern of spreading from optimal growth areas to less optimal ones (Nichols and Shaw 1986). Causes of declines are still under discussion, but initial stages of declines are commonly attributed to a large decrease in water transparency as a consequence of increases in total suspended-solids concentrations and in algal growth, respectively.

Milfoil is considered a nuisance plant in parts of the United States, since it may interfere with human utilization of freshwater resources, become aesthetically displeasing, or displace desirable indigenous communities. From a shoreline perspective, the biomass in a dense "mat" of submersed weeds appears to be enormous. However, data on total biomass and productivity indicate that they are small compared with those of several terrestrial plant communities (Spencer and Bowes 1990). This apparent anomaly may be largely due to the uneven distribution of biomass over the water column, with typically $>60$ percent concentrated in the upper-water layers.

The simulation model developed in this study concerns Eurasian watermilfoil. The following appendixes are included in this report: Model Listing as Appendix A, Variable Listing as Appendix B, and Manipulation of Literature Data Used for the Model Equations as Appendix C. A user manual is published separately (Best and Boyd, in preparation). 


\section{MILFO: Description of Model}

\section{Modeling Concepts}

The MILFO (Version 1.0) model simulates growth of a typically monoecious Eurasian watermilfoil community. In the model, growth is considered the plant dry matter accumulation including rhizome/root crown formation, under ample supply of nitrogen and phosphorus, in a pest-, disease-, and competitor-free environment under the prevailing weather conditions. Two or three plant cohorts in, respectively, temperate or tropical areas wax and wane per season with one and the same rhizome/root crown system as a common basis. The rate of dry matter accumulation is a function of irradiance, temperature, $\mathrm{CO}_{2}$ availability, and plant characteristics. The rate of $\mathrm{CO}_{2}$ assimilation (photosynthesis) of the plant community depends on the radiant energy absorbed by the canopy, which is a function of incoming radiation, reflection at the water surface and attenuation by the water column, attenuation by the plant material, and leaf area of the community. From the absorbed radiation, the photosynthetic characteristics of individual shoot tips, and the $\mathrm{pH}$-determined $\mathrm{CO}_{2}$ availability, the daily rate of gross $\mathrm{CO}_{2}$ assimilation of the community is calculated. These calculations are executed in a set of subroutines added to the model.

Part of the carbohydrates produced is used to maintain the existing biomass. The remaining carbohydrates are converted into structural dry matter (plant organs). In the process of conversion, part of the weight is lost in respiration. The dry matter produced is partitioned among the various plant organs using partitioning factors defined as a function of the phenological cycle of the community. The dry weights of the plant organs are obtained by integration of their growth rates over time. The plant winters through a system composed of root crowns attached to a rhizome system in the sediment with or without aboveground plant biomass present. All calculations are performed on a $\mathrm{m}^{2}$ basis. Since environmental factors and plant growth characteristics vary with depth, in the model the water column and associated growth-related processes have been partitioned in 0.10-m depth classes (Titus et al. 1975). 
Seed formation has not been included in the model because its role in maintaining an existing milfoil community at the same location is minimal (Hartleb, Madsen, and Boylen 1993). Dispersal and colonization of new habitats by plant fragments and seeds are recognized, important characteristics of Eurasian watermilfoil. The latter processes, however, are better described using other modeling approaches (based on logistic regression or on descriptions of population dynamics varying in time and in space), as discussed by Scheffer (1991).

MILFO requires as input physiological properties of the plant community (in this case of milfoil) and of the actual environmental and weather conditions at the site, characterized by geographical latitude and longitude, i.e., water temperatures (optional), alkalinity, $\mathrm{pH}$, and daily maximum and minimum temperatures and irradiance for each day of the year. It can be run for periods of 1 to 5 years.

\section{Modeling Approach}

MILFO is a mechanistic model that explains plant growth on the basis of the underlying processes, such as $\mathrm{CO}_{2}$ assimilation and respiration, as influenced by environmental conditions. This type of model follows the state-variable approach in that it is based on the assumption that the state of each system can be quantified at any moment and that changes in the state can be described by mathematical equations. In this type of model, state, rate, and driving variables are distinguished. State variables are quantities such as biomass and number of individuals of a population. Driving variables characterize the effect of environment on the system at its boundaries, such as climate and food supply. Each state variable is associated with rate variables that characterize its rate of change at a certain instant, as a result of specific processes. These variables represent flows of material between state variables, the values of which are calculated from the state and driving variables according to knowledge of the physical, chemical, and biological processes involved. After calculating the values of all rate variables, they are then used to calculate the state variables according to the scheme: state variable at time $t+\Delta t$ equals state variable at time $t$ plus the rate at time $t$ multiplied by $\Delta t$. This procedure, called numerical integration, gives the new values of the state variables, from which the calculation of rate variables is repeated. To avoid instabilities, the time interval $\Delta t$ must be small enough so that the rates do not change materially within this period. This is generally the case when the time interval of integration is smaller than one-tenth of the "time coefficient" or "response time." This characteristic time of a system is equal to the inverse of the most rapid relative rate of change of one of its state variables. The smaller the time coefficient, the smaller the time interval of integration (Rabbinge and De Wit 1989).

The predictive ability of mechanistic models does not always live up to expectations. It should be realized, however, that each parameter estimate and process formulation has its own uncertainty, and that uncertainties in parameter 
estimates may accumulate in the prediction of the final yield. The primary aim of this model is to increase insight in the system studied by quantitatively integrating the current knowledge in a dynamic simulation model. By studying the behavior of such a model, better insight in the real system is gained.

\section{Implementation}

The MILFO model was implemented as a FORTRAN77 program. For numerical integration, the Runge-Kutta technique is used, which allows employing a variable time-step. The program, as it is being run, integrates the equations once per day in the main subroutines (MODEL, CHRT2, CHRT3; see Figure 1), once per second in the subroutines calculating day length and instantaneous irradiance (ASTRO) and instantaneous gross assimilation (ASSIM), and at three times of the day in the subroutine calculating daily total gross assimilation (TOTASS; Gaussian integration). Instantaneous gross assimilation is calculated per second and converted to hourly rates within ASSIM.

Model approach and organization are similar to those used for agricultural crops (SUCROS1; Goudriaan, Van Keulen, and Van Laar 1992). Several features of a simulation model for hydrilla (HYDRIL; Best and Boyd 1996; Boyd and Best 1996) and of a general growth model for submersed angiosperms (SUBANG; Best and Jacobs 1990) have been used.

MILFO runs within a FORTRAN SIMULATION ENVIRONMENT (FSE) shell, Version 2.1, to enable easy handling of input and output files and rapid visualization of the simulation results (Van Kraalingen 1995). It can be executed on IBM PC- ATs and compatibles as a stand-alone version. Because of its language and simple structure, it will generally be compatible with ecosystem models that accept FORTRAN.

The organization of the model and its subroutines in combination with the FSE shell is illustrated in Figure 1.

\section{Model Features}

Features of MILFO are as follows:

a. Phenology is tied indirectly to air temperature through development rate and is, therefore, independent of day number; thus, the model can be used under climatological conditions ranging from temperate to tropical.

$b$. Plant growth starts from the rhizome/root crown system alone or from the same system with wintering plants. 


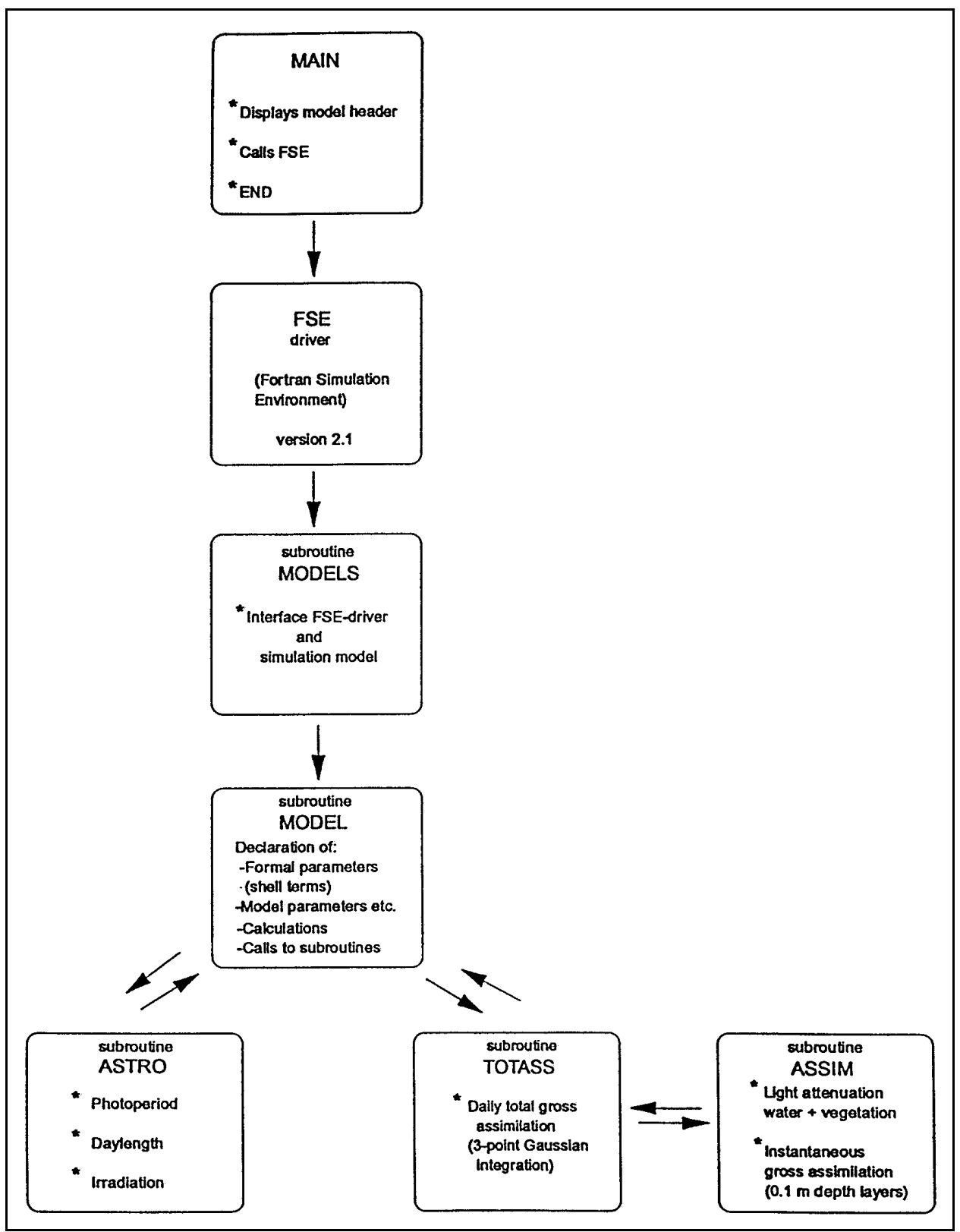

Figure 1. Relational diagram of MILFO and its subroutines in combination with FSE shell (Each plant cohort is represented by a cohort-specific subroutine (cohort 1 by MODEL, cohort 2 by CHRT2, and cohort 3 by CHRT3; only one shown), all using same subroutines ASTRO, TOTASS, and ASSIM) 
c. Two plant cohorts are active in a temperate climate and three cohorts in the tropics, depending on the seasonal input variables.

d. Photosynthetic response is to instantaneous irradiance.

e. Removal of biomass through mechanical harvesting can be calculated.

f. Air or water temperatures must be used to run the model.

g. The model can be used for communities at various water depths, ranging from 0.5 to $6.0 \mathrm{~m}$.

h. Plant parameter values and climatological variables can be easily changed. 


\section{Model Processes}

\section{Morphology, Phenological Cycle, and Development}

\section{Morphology and phenological cycle of milfoil}

Eurasian watermilfoil is a rooted perennial with long, flexible stems and finely dissected leaves. The leaves are arranged in whorls around the stems. The plant stems may reach lengths in excess of $4 \mathrm{~m}$ in summer, branching close to the water surface (canopy formation). It has been found in water depths ranging from 0.2 to $6 \mathrm{~m}$ (Grace and Wetzel 1978; Madsen, Eichler, and Boylen 1988). It occasionally forms small emergent shoots from fragments starting on the shore. ${ }^{1}$ The current model does not describe plants in emergent habit.

Milfoil is able to propagate itself by seeds, by vegetative fragmentation, and in an evergreen condition. Flowering of milfoil in the northern hemisphere occurs from June to November; one (Aiken, Newroth, and Wile 1979; Grainger 1947; Carpenter 1980), two (Nichols 1971; Lind and Cottam 1969; Patten 1956), and three (Grace and Wetzel 1978) flowering periods per year have been reported. Flowering periods in southern areas have been described as "less predictable" (Grace and Wetzel 1978), while they are suggested to occur in the tropics during the whole growth season (Zutschi and Vass 1973). Flowering usually coincides with peak biomass and is followed immediately by autofragmentation/sloughing. The production of viable seeds requires emersion of the typically monoecious flowering spikes (Patten 1954) with transfer of pollen by wind as the dominant pollination mechanism (Hutchinson 1975). Seeds are important in long-distance dispersal and as insurance against local extinction, but seed germination may be delayed (Guppy 1897; Patten 1955) or decreased by desiccation (Standifer and Madsen 1997); seedling establishment appears to be a particularly fragile stage in the life cycle (Patten 1956; Hartleb, Madsen, and Boylen 1993). Shoot fragmentation is usually the result of abscission just after flowering, but it can also be accidental (by boat contact or wave action). Although shoot fragmentation can be substantial, the number of

1 Personal Communication, 1998, J. E. Titus, University of Binghamton, New York. 
established, new plants originating from shoot fragments is relatively low (Madsen and Smith 1997). Fragmentation is probably the most important means of dispersal within a water body or between nearby water bodies. Milfoil most frequently winters in an evergreen form as root crowns and/or lower shoots attached to the rhizome system (Grace and Wetzel 1978; Madsen, Eichler, and Boylen 1988; Madsen 1997) and may maintain considerable winter biomass (Stanley et al. 1976). This species does not form turions described as important hibernacula of other Myriophyllum species (M. exalbescens, M. verticillatum, M. heterophyllum; Grace and Wetzel 1978).

\section{Description of development and phenological cycle in MILFO}

The phenology of a plant community, for which development phase can be used as a measure, quantifies physiological age and is related to its morphological appearance. Development phase cannot be expressed simply as chronological age because several environmental factors such as temperature and stress (e.g., nutrients, grazing) can speed up or reduce the rate of phenological development. Contrary to what is suggested by intuition, the rate of plant growth per se has no effect on phenological development, as long as the growth rate is not very low (Penning de Vries et al. 1989b, and citations therein). The concept of development phase is used to characterize the whole plant community; it is not appropriate for individual organs.

The response of developmental rate to temperature in the current model is in accordance with the degree-day hypothesis (Thornley and Johnson 1990a). The idea is as follows. The mean temperature $T_{i}$ for each day $i$ is measured, and a sum $h$ is formed according to

$$
h=\sum_{i=1}^{j}\left(\bar{T}_{i}-T_{c}\right)
$$

which includes only those terms where $T_{i}$ is above some threshold value $T_{c}$. When $h$ reaches a particular value, this signifies that a phase in development is complete, and this is generally associated with a biological event that occurs over a short period of time and is readily observed. The day-degree sum $h$ essentially integrates some underlying temperature-dependent processes. For milfoil, for example, there are various phases in the development of the plant, and the temperature sum is found to have a certain value for the successful completion of each. The temperature threshold $T_{c}$ may be different for each of these phases. The approach is based on the notion of a developmental rate, whose response to temperature is approximately linear over a restricted temperature range. Comparison with actual temperature responses found in agricultural crops suggests that this is not unreasonable, and the method works well in practice. It is implicitly assumed that the organ possesses a developmental clock that is proceeding at the rate $k_{d}$. In general, it is to be expected that the development rate $k_{d}$ may depend on a number of quantities. This can be represented by 


$$
k_{d}=f(V, P, E)
$$

in which $f$ represents some function of the state variables $V$, parameters $P$, and environmental quantities $E$. The temperature-sum rule works because the most important environmental variable is temperature, and the response to temperature is approximately linear.

The phenological cycle is described using milfoil in Lake Wingra, Wisconsin, in 1970 as an example (Adams and McCracken 1974). Plant data of this year were chosen after verifying that climatological conditions did not deviate from the usual at that site.

Development phase (DVS) is a state variable in MILFO. The development phase is dimensionless, and its value increases gradually within a growing season. The development rate has the dimension $\mathrm{d}^{-1}$. The multiple of rate and time period yields an increment in phase. In the model, the temperature that affects development of milfoil can be chosen as equal to the daily average air temperature at the height of the growing point of the shoots, with a user-defined lagperiod to correct for deviations in temperature of the water body in which the aquatic community grows compared with air temperatures ( 7 days is nominal). It is more accurate to use water temperatures for this purpose; but since water temperatures are not always available for the site for which the user wants to run the model, MILFO can be run using either one.

The rate of phenological development can be affected by temperature differently in the vegetative phase and in the reproductive phase. These differences indicate that the physiological process of development may not be the same before and after anthesis. Descriptions in literature of number of flowering periods per year and their timing in milfoil indicate that from June to November usually two flowering periods, in June and July, occur in temperate climates, sometimes three in southern regions, and usually three in tropical climates (Zutschi and Vass 1973).

The following development rates were derived from the Lake Wingra field data, pertaining to two plant cohorts each with its own flowering period (Adams and McCracken 1974): of $0.022 \mathrm{~d}^{-1}$ prior to the first flowering period and of $0.015 \mathrm{~d}^{-1}$ subsequently, at a reference temperature of $30{ }^{\circ} \mathrm{C}$ and a temperature threshold of $3{ }^{\circ} \mathrm{C}$. These development rates are considered as typical for temperate regions.

For milfoil populations in the tropics, the same development rates and timings as in temperate regions were applicable, but a third plant cohort had to be added to accommodate the third flowering period and usually high August biomass in India (Zutschi and Vass 1973). The milfoil development rates are somewhat higher than those found for hydrilla $\left(0.012 \mathrm{~d}^{-1}\right.$ at the same reference temperature and threshold temperature as used for milfoil).

The development phase has the value zero when the simulation starts at the first Julian day number (Tables 1 and 2). The simulation starts using observed 


\begin{tabular}{|c|c|c|c|}
\hline \multicolumn{4}{|c|}{$\begin{array}{l}\text { Table } 1 \\
\text { Relationship Between Development Phase (DVS) of Milfoil, Day of Year, and } 3{ }^{\circ} \mathrm{C} \text { Day- } \\
\text { Degree Sum for a Temperate Climate (DVRVT=0.022; DVRRT=0.015) }\end{array}$} \\
\hline \multicolumn{2}{|l|}{ Developmental phase } & \multirow[b]{2}{*}{ Day Number } & \multirow[b]{2}{*}{$\begin{array}{l}3^{\circ} \mathrm{C} \text { Day-Degree } \\
\text { Sum }\end{array}$} \\
\hline Description & DVS Value & & \\
\hline $\begin{array}{l}\text { First Julian day number -> sprouting, initiation elongation, and } \\
\text { leaf expansion COHORT1 }\end{array}$ & $0->0.375$ & $0->114$ & $1->191$ \\
\hline $\begin{array}{l}\text { Sprouting, initiation elongation, and leaf expansion -> floral } \\
\text { initiation, anthesis, and induction of senescence COHORT1 }\end{array}$ & $0.376->1.000$ & $115->162$ & $192->900$ \\
\hline $\begin{array}{l}\text { Floral initiation, anthesis, and induction of senescence } \\
\text {-> senescence COHORT1 }\end{array}$ & $1.001->1.630$ & $163->212$ & $901->2012$ \\
\hline Senescence -> senesced COHORT1 & $1.631->2.000$ & $213->245$ & 2013-> 2669 \\
\hline $\begin{array}{l}\text { Sprouting, initiation elongation, and leaf expansion -> floral } \\
\text { initiation, anthesis, and induction of senescence COHORT2 }\end{array}$ & $1.001->1.630$ & $163->212$ & $901->2012$ \\
\hline $\begin{array}{l}\text { Floral initiation, anthesis, and induction of senescence } \\
->\text { anthesis and senescence COHORT2 }\end{array}$ & $1.631->2.000$ & $213->245$ & $2013->2669$ \\
\hline Senescence -> senesced COHORT2 & $2.001->2.570$ & $246->365$ & $2670->3508$ \\
\hline Senesced COHORT 1 and 2 & 2.570 & 365 & 3508 \\
\hline
\end{tabular}

weights of plants and rhizome/root crowns as initial values. Initial plant weights have been set equal to the observed shoot weight early in spring, which is believed to give a fair approximation. Since the initial weight of the rhizome/ root crown system had not been measured in the calibration data set, this weight has been set equal to $50 \mathrm{~g} \mathrm{DW} \mathrm{m}^{-2}$ found for a similar milfoil community in the same lake in 1977 (Smith and Adams 1986). The rhizome/root crown system is the common basis from which milfoil plant cohorts develop. Plant cohorts are plant groups exhibiting the same phenological cycle, and plants are considered as units composed of roots, stems, and leaves, excluding the rhizome/root crown system. If simulation of the community at another site is desired, the simulation can start from other initial biomass values, either from the rhizome/root crown system only or with wintering plant biomass present.

For a milfoil community in a temperate climate (Table 1), the sprouting of the rhizome/root crown system, i.e., the initiation of growth activity, occurs at DVS 0.375. Sprouts of plant cohort 1 develop through remobilization of carbohydrates from the rhizome/root crown system. The sprouts elongate rapidly to the water surface and form a canopy in the upper-water layers. Anthesis of cohort 1 is initiated at DVS 1.000 and finishes at DVS 1.630, just before downward carbohydrate translocation and senescence are initiated. Translocation and senescence of cohort 1 set in at DVS 1.631 and continue until DVS 2.000. Sprouting of cohort 2 starts when translocation and scenescence of cohort 1 have set in. This timing is based on the assumption that at that time, apical dominance by the existing, senescing shoots is broken and, consequently, new shoots can develop. 


\begin{tabular}{|c|c|c|c|}
\hline \multicolumn{4}{|c|}{$\begin{array}{l}\text { Table } 2 \\
\text { Relationship Between Development Phase (DVS) of Milfoil, Day of Year, and } 3{ }^{\circ} \mathrm{C} \text { Day- } \\
\text { Degree Sum for a Tropical Climate (DVRVT=0.022; DVRRT=0.015) }\end{array}$} \\
\hline \multicolumn{2}{|l|}{ Developmental phase } & \multirow[b]{2}{*}{ Day Number } & \multirow[b]{2}{*}{$\begin{array}{l}3^{\circ} \mathrm{C} \text { Day-Degree } \\
\text { Sum }\end{array}$} \\
\hline Description & DVS Value & & \\
\hline $\begin{array}{l}\text { First Julian day number -> sprouting, initiation elongation, and } \\
\text { leaf expansion COHORT1 }\end{array}$ & $0->0.375$ & $0->25$ & $1->431$ \\
\hline $\begin{array}{l}\text { Sprouting, initiation elongation, and leaf expansion -> floral } \\
\text { initiation, anthesis, and induction of senescence COHORT1 }\end{array}$ & $0.376->1.000$ & $26->61$ & $432->1163$ \\
\hline $\begin{array}{l}\text { Floral initiation, anthesis, and induction of senescence } \\
->\text { senescence COHORT1 }\end{array}$ & $1.001->1.630$ & $62->162$ & $1164->3844$ \\
\hline Senescence -> senesced COHORT1 & $1.631->2.000$ & $163->188$ & $3845->4490$ \\
\hline $\begin{array}{l}\text { Sprouting, initiation elongation, and leaf expansion -> floral } \\
\text { initiation, anthesis, and induction of senescence COHORT2 }\end{array}$ & $1.001->1.630$ & $62->162$ & $1164->3844$ \\
\hline $\begin{array}{l}\text { Floral initiation, anthesis, and induction of senescence } \\
->\text { anthesis and senescence COHORT2 }\end{array}$ & $1.631->2.000$ & $163->188$ & $3845->4490$ \\
\hline Senescence -> senesced COHORT2 & $2.001->2.570$ & $164->233$ & 4491 -> 5492 \\
\hline $\begin{array}{l}\text { Sprouting, initiation elongation, and leaf expansion -> floral } \\
\text { initiation, anthesis, and induction of senescence COHORT3 }\end{array}$ & $2.001->2.447$ & $164->223$ & 4491 -> 5273 \\
\hline $\begin{array}{l}\text { Floral initiation, anthesis, and induction of senescence } \\
->\text { senescence COHORT3 }\end{array}$ & $2.448->3.500$ & $224->307$ & $5274->7125$ \\
\hline Senescence -> senesced COHORT3 & $3.501->4.141$ & $308->365$ & 7126 -> 8254 \\
\hline Senesced COHORT 1,2, and 3 & 4.141 & 365 & 8254 \\
\hline
\end{tabular}

Sprouting of cohort 2 occurs from growing points on the rhizome/root crown system. Anthesis of cohort 2 is initiated at DVS 1.631 and finishes at DVS 2.000. Translocation and senescence of cohort 2 set in at DVS 2.001 and continue until the end of the year.

For a milfoil community in the tropics (Table 2), it proved impossible to generate the high levels of shoot and rhizome/root crown biomass reported (Zutschi and Vass 1973) with two plant cohorts active since the second plant cohort had already senesced in May. However, proper biomass levels and timing were attained with three plant cohorts active, the third cohort being switched on at latitudes less than $33^{\circ} \mathrm{N}$. It is possible that a particular plant process, like sprouting, is sensitive to day length and that this process decides for the population to activate another cohort. However, since the authors are not aware of publications on this topic for milfoil, the switch has been set at the cut-off latitude for tropical areas. Plant cohorts in tropical regions behave similar in terms of DVS to those in temperate regions, except that tropical cohorts require on average a $1.6 \times$ higher $3^{\circ}$ degree-day sum to complete their individual life cycle than temperate cohorts. 


\section{Maximum Biomass and Plant Density}

Seasonal biomass maxima have been reported to vary considerably over time and space. In temperate climates, sometimes one, but usually two, biomass peak(s) were found per growth season. Biomass maxima appear to be related to flowering period. One distinct biomass maximum has been reported for tropical areas (India), while flowering started in May and continued during the growth season. The highest standing crop of 2,283 $\mathrm{g} \mathrm{DW} \mathrm{m}^{-2}$ has been found in Fish Lake, Wisconsin (Budd, Lillie, and Rasmussen 1995), and similar values have been reported for the more southern Lake Guntersville, Alabama, in 1972 (Stanley et al. 1976). This maximum biomass value found has been used to form the upper limit of plant biomass in the model.

Generally, biomass production of milfoil is far more constrained by plantinherent factors, light and space availability and temperature, than by plant density. As the season progresses, the individual plant size increases along with the areal biomass, and thinning of shoots caused by intraspecific interference results in an inverse relationship between plant size and plant density (Lind and Cottam 1969).

However, since initial plant density is required as an input variable into the model, a feasible plant density under field conditions had to be found. A range of 3 to 32 so-called "plant clumps" $\mathrm{m}^{-2}$, consisting of a variable number of stems, were determined for a milfoil community in Fish Lake, Wisconsin, in the summers of 1990-92 (Budd, Lillie, and Rasmussen 1995). The mean value of 11 plants $\mathrm{m}^{-2}$, with clump used synonymously to plant, has been used in the model.

In MILFO, plant density has been set to 11 plants $\mathrm{m}^{-2}$. This implies that plant density is always $11 \mathrm{~m}^{-2}$ at the beginning of the growth season, and that biomass is redistributed over 11 plants $\mathrm{m}^{-2}$ if wintering plants are present.

\section{Wintering and Sprouting of Rhizomes/ Root Crowns and Growth of Sprouts to Water Surface}

Rhizome/root crown tissues were the main storage area for carbohydrates in wintering milfoil. Starch concentrations may reach 20 percent, with total nonstructural carbohydrates (TNC) concentrations of up to 30-40 percent (Titus and Adams 1979b; Madsen 1997). Rhizome/root crown biomass tended to be higher in spring and in autumn than during the rest of the year and showed an inverse relationship with plant cohort biomass. It fluctuated between 12 and $400 \mathrm{~g} \mathrm{DW}$ $\mathrm{m}^{-2}$ because of seasonal changes (Madsen 1997). Rhizome/root crown biomass of the milfoil community in Lake Wingra amounted to $50 \mathrm{~g} \mathrm{~m}^{-2}$ in winter 1977 (Smith and Adams 1986), while it was relatively constant in tropical regions, varying between 32 and $48 \mathrm{~g} \mathrm{DW} \mathrm{m}^{-2}$ (Zutschi and Vass 1973). 
In the model, rhizome/root crown weight decreases by sprouting of growing points, which transform into plants, by respiration, by a plant-inherent sloughing process, and, possibly, by grazing by waterfowl or other organisms, and it increases by downward carbohydrate translocation.

Sprouting or regrowth potential of the rhizome/root crown system is usually high and occurs early in the season. Sprouting in southern areas like Texas (latitude $33{ }^{\circ} \mathrm{N}$, longitude $97{ }^{\circ} \mathrm{E}$ ) has been reported to occur already in March (Madsen 1997). In northern areas, the timing of sprouting may be similar, but no observations confirming this have been made (or published) probably since at that time, water temperatures are still very low, impeding field work. Actual sprouting frequency under natural conditions is unknown. Sprouting frequency in an established community is probably not important, as long as the final plant density of 11 plants $\mathrm{m}^{-2}$ is somehow reached, since plant density tends to play a lesser role in biomass production compared with space availability (see Maximum Biomass and Plant Density). Sensitivity to day length at which the rhizome/root crown systems sprout, or triggering by red-far red ratio, has not been reported.

It is to be expected that the rhizome/root crown system requires continuous maintenance, but that maintenance processes proceed at a low level of activity because of the relatively high carbohydrate concentrations that are cheap in maintenance costs (Penning de Vries and Van Laar 1982b).

Sloughing or death rates of rhizomes/root crowns have not been published so far. A death rate value has been derived from observations on terrestrial rhizome systems where annual turnover rates were found to be approximately four times less than those of aboveground plant biomass in the growth season, but could drop with a factor of 1/100 in inactive periods (Vogt, Vogt, and Bloomfield 1991). Following this approach, a tentative relative death rate of $0.00042 \mathrm{~d}^{-1}$ was calculated $\left(\mathrm{g} \mathrm{DW} \mathrm{g} \mathrm{DW}^{-1} \mathrm{~d}^{-1}\right)$, being $1 / 100$ of the plant death rate. The latter value is far lower than that of $0.36 \mathrm{~d}^{-1}$ estimated for hydrilla tubers from simulations (Best and Boyd 1996). However, the death rate of hydrilla tubers may be an overestimate since death by grazing and/or disturbance of sediments was included in that overall death rate, and grazing of tubers, e.g., by waterfowl, is usually high (Jupp and Spence 1977; Scheffer, Bakema, and Wortelboer 1993). Effects of grazing on the milfoil rhizome/root crown systems are unknown, but expected to be far lower than on hydrilla tubers.

In MILFO, initial rhizome/root crown biomass has been set at $50 \mathrm{~g}$ AFDW m ${ }^{-2}$, equal to the below-ground biomass measured at $1.5-\mathrm{m}$ rooting depth in Lake Wingra in 1977 (Smith and Adams 1986) and equal to the lowest shoot biomass found in 1970 (Adams and McCracken 1974). Sprouting is a function of devel-opment phase through the $3{ }^{\circ} \mathrm{C}$ day-degree sum; it occurs between DVS 0.375 and the flowering period for cohort 1, between DVS 1.001 and the flowering period for cohort 2, and, when active, between DVS 2.001 and the flowering period for cohort 3. Sprouting frequency has been set equal to the number of plants per surface area, i.e., at 11 sprouts $\mathrm{m}^{-2}$ (sprout is used here synonymously with plant clump). 
Remobilization can occur provided the weight of the rhizome/root crown system is greater than the critical rhizome weight. The critical rhizome weight value is the lowest value published, i.e., $12.0 \mathrm{~g} \mathrm{DW} \mathrm{m}^{-2}$ (Madsen 1997).

The rhizomes sprout by remobilization, i.e., conversion of part of their carbohydrate reserves into sprout material, via a relative conversion rate of rhizometo-plant (ROC), with the same value as derived for conversion of hydrilla tubers (0.0576 $\mathrm{g} \mathrm{CH}_{2} \mathrm{O}$ g rhizome/root crown- $\mathrm{DW}^{-1} \mathrm{~d}^{-1}$; for calculation, see Best and Boyd 1996). These carbohydrates are allocated to the plant organs according to a fixed biomass allocation pattern (see next section). It is assumed that the sprouts can elongate up to the water surface by mere remobilization processes, not even requiring photosynthetic products, since potential sprout elongation has been estimated to be $12 \mathrm{~m}$ sprout-length $\mathrm{g} \mathrm{DW}^{-1}$ (for hydrilla, cf. Best and Boyd 1996; it is assumed to be similar for milfoil).

After reaching the water surface, canopy formation takes place and photosynthesis proceeds.

Maintenance processes are treated in the next section.

The relative rhizome death rate has been set at $0.00042 \mathrm{~d}^{-1}$ (on dry weight basis).

A relational diagram illustrating the wintering and sprouting rhizomes/root crowns of milfoil is shown in Figure 2.

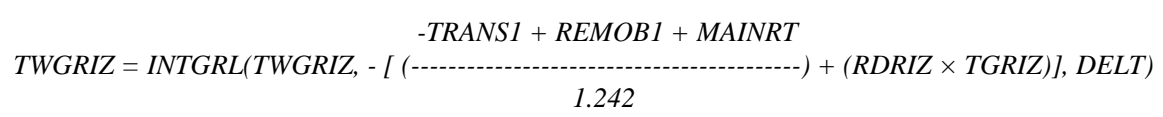

IF (DVS. GE. 0.376. AND. DVS. LT. 1.0) THEN

IF (TWGRIZ. GT. CRRIZ) THEN

$R E M O B 1=R O C \times T W G R I Z$

$T W R I Z D=I N T G R L(T W R I Z D, R D R I Z, D E L T)$

where

$T W G R I Z=$ total live dry weight of rhizome/root crown system of current day $\left(\mathrm{g} \mathrm{DW} \mathrm{m}^{-2}\right.$ )

REMOB1 $=$ remobilization rate of carbohydrates cohort $1\left(\mathrm{~g} \mathrm{CH}_{2} \mathrm{O} \mathrm{m}^{-2} \mathrm{~d}^{-1}\right)$

MAINRT = maintenance respiration rate of rhizome/root crown system $\left(\mathrm{g} \mathrm{CH}_{2} \mathrm{O} \mathrm{m}^{-2} \mathrm{~d}^{-1}\right)$

1.424 = assimilate requirement for rhizome dry matter production ( $\mathrm{g} \mathrm{CH}_{2} \mathrm{O} \mathrm{g} \mathrm{DW}^{-1}$; see Appendix $\mathrm{C}$ )

$R D R I Z=$ relative death rate of rhizome/root crown system $\left(\mathrm{d}^{-1}\right)$ 


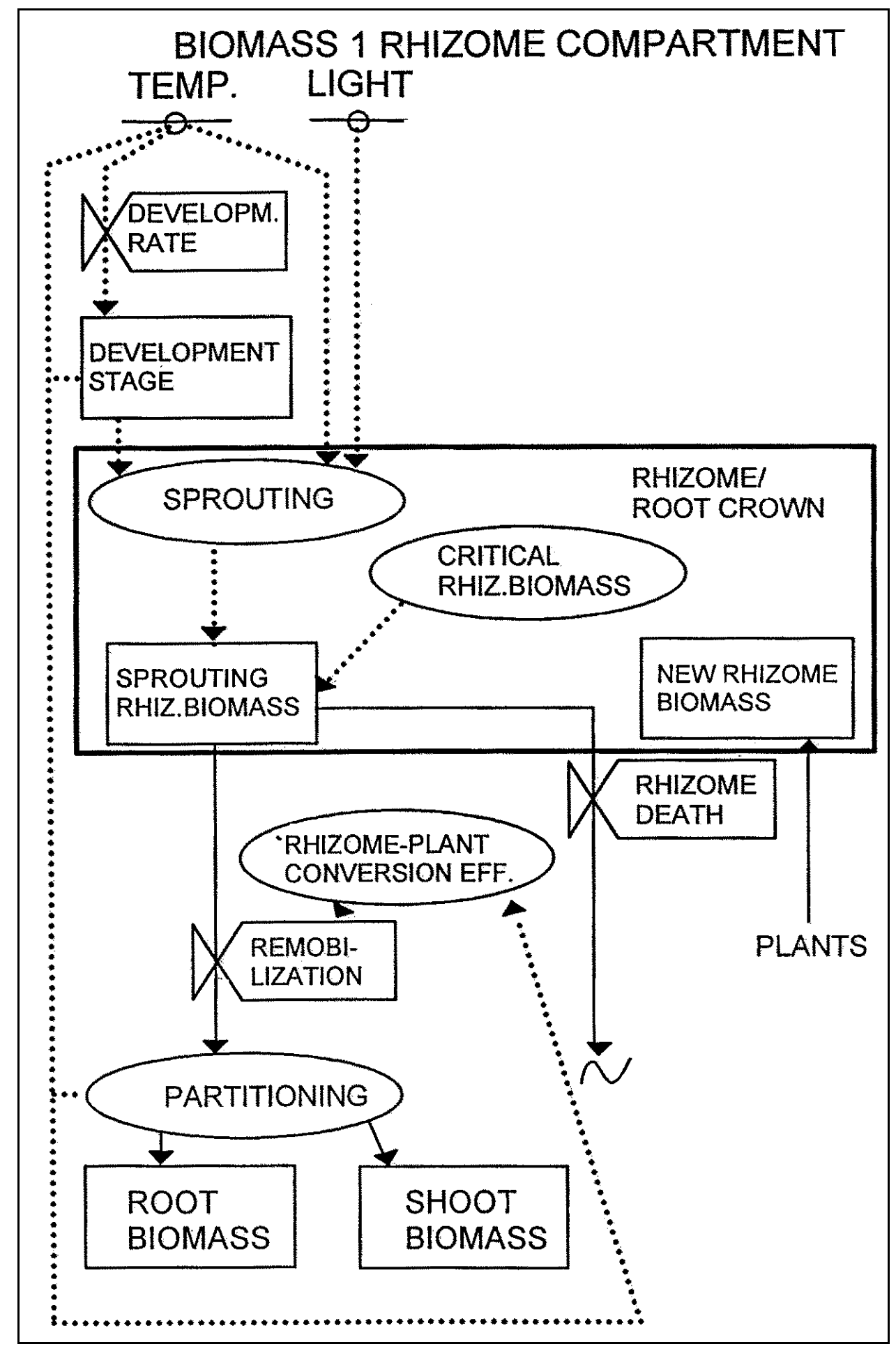

Figure 2. Relational diagram illustrating wintering and sprouting of rhizomes/root crowns in milfoil 
$T G R I Z=$ total live dry weight rhizome/root crown system of previous day $\left(\mathrm{g} \mathrm{DW} \mathrm{m}^{-2}\right)$

$D V S=$ developmental phase of plant (-)

$C R R I Z=$ critical weight of rhizome/root crown system $\left(\mathrm{g} \mathrm{DW} \mathrm{m}^{-2}\right)$

$R O C=$ relative conversion rate of rhizome/root crown into plant material $\left(\mathrm{g} \mathrm{CH}_{2} \mathrm{O} \mathrm{g} \mathrm{DW}^{-1} \mathrm{~d}^{-1}\right.$ )

$T W R I Z D=$ total weight of dead rhizome/root crown system $\left(\mathrm{g} \mathrm{DW} \mathrm{m}^{-2}\right)$

\section{Light, Photosynthesis, Maintenance, Growth, and Assimilate Partitioning in Milfoil Plants}

\section{Light}

The measured daily total irradiance (wavelength $300-3,000 \mathrm{~nm}$ ) is used as input for the model. Only half of the irradiance reaching the water surface is photosynthetically active and is therefore used to calculate $\mathrm{CO}_{2}$ assimilation. Six percent of the irradiance is reflected by the water surface (Golterman 1975).

The subsurface irradiance is attenuated by dissolved substances and particles within the water column resulting in a site- and season-specific extinction coefficient. Moreover, the vertical profiles of the radiation within the community layers are characterized. The absorbed irradiance for each horizontal community layer is derived from these profiles. The community-specific extinction coefficient $K$ is assumed to be constant throughout the year and given a value of $0.006 \mathrm{~m}^{2} \mathrm{~g} \mathrm{DW}^{-1}$ measured in the milfoil community in Lake Wingra (Titus and Adams 1979a). Another higher, community-specific extinction coefficient of $0.01 \mathrm{~m}^{2} \mathrm{~g} \mathrm{DW}^{-1}$ has been published by Ikusima (1970) for a milfoil community in Japan, which may indicate that plants at lower latitudes have thinner leaves.

The incoming irradiance is attenuated by the shoots, part of which is absorbed by the photosynthetic plant organs, i.e., the leaves.

$$
\begin{aligned}
& I R Z_{i+1}=I R Z_{i} \times e^{\left(-T L \times L-K \times S C_{i}\right)} \\
& I A B S_{i}=\frac{\left(I R Z_{i}-I R Z_{i+1}\right) \times S C_{i} \times K}{\left(K \times S C_{i}+T L \times L\right)} \\
& I A B S L_{i}=I A B S_{i} \times F L
\end{aligned}
$$


where

$$
\begin{gathered}
I R Z(i)=\underset{\text { photosynthetic active part of total irradiance on top of depth layer }}{i\left(\mathrm{~J} \mathrm{~m}^{-2} \mathrm{~s}^{-1}\right)} \\
T L=\text { thickness depth layer }(0.10 \mathrm{~m}) \\
L=\text { light extinction coefficient of water }\left(\mathrm{m}^{-1}\right) \\
K=\text { plant-specific extinction coefficient }\left(\mathrm{m}^{2} \mathrm{~g} \mathrm{DW}^{-1}\right) \\
\left.S C=\text { shoot matter ( } \mathrm{g} \text { DW per } 0.1 \mathrm{~m} \text { stratum of a } \mathrm{m}^{2} \text { water column }\right) \\
I A B S(i)=\text { total irradiance absorbed in depth layer } i\left(\mathrm{~J} \mathrm{~m}^{-2} \mathrm{~s}^{-1}\right) \\
I A B S L(i)=\text { total irradiance absorbed by plant shoots in depth layer } i\left(\mathrm{~J} \mathrm{~m} \mathrm{~m}^{-2} \mathrm{~s}^{-1}\right) \\
F L=\text { leaf dry matter allocation to each layer of the plant (relative) }
\end{gathered}
$$

\section{Photosynthesis}

The instantaneous rates of gross assimilation are calculated from the absorbed light energy and the photosynthesis light response of individual shoot apices, here used synonymously to leaves.

The photosynthesis light response of leaves is described by the exponential function

$$
F G L=S C_{i} \times A M A X \times\left(1-\exp \left[\frac{-E E \times I A B S_{i} \times 3600}{A M S \times S C_{i}}\right]\right)
$$

where

$$
\begin{aligned}
& F G L=\text { gross assimilation rate per depth layer }\left(\mathrm{g} \mathrm{CO}_{2} \mathrm{~m}^{-1} \mathrm{~h}^{-1}\right) \\
& S C(i)=\text { standing crop in depth layer } i\left(\mathrm{~g} \mathrm{DW} \mathrm{m}^{-2} \text { layer }^{-1}\right) \\
& A M A X=\text { actual } \mathrm{CO}_{2} \text { assimilation rate at light saturation for individual shoots } \\
& \left(\mathrm{g} \mathrm{CO}_{2} \mathrm{~g} \mathrm{DW}^{-1} \mathrm{~h}^{-1}\right) \\
& E E=\text { initial light-use efficiency for shoots }\left(\mathrm{g} \mathrm{CO}_{2} \mathrm{~J}^{-1} \text { absorbed }\right)
\end{aligned}
$$


Bowes, Holaday, and Haller 1979; Van, Haller, and Bowes 1976). Light- and carbon-saturated photosynthetic rates can be far higher (Van, Haller, and Bowes 1976), suggesting that photosynthetic activity in lakes like Lake Wingra, where DIC concentrations are in the range of 0.8 to $3.5 \mathrm{mmol}$ with a $\mathrm{pH}$ of 7.6 to 9.4 (Lee and Kluesener 1972), can be carbon limited.

For photosynthetic light-use efficiency (EE), a value of $11.10^{-6} \mathrm{~g} \mathrm{CO}_{2} \mathrm{~J}^{-1}$, typical for $\mathrm{C}_{3}$ plants, was used (Penning de Vries and Van Laar 1982a). Substituting the appropriate value for the absorbed photosynthetically active radiation yields the assimilation rate for each specific shoot layer.

Gross assimilation rate at light saturation shows a distinct seasonal pattern and tends to decrease with aging (Adams and McCracken 1974; Adams, Titus, and McCracken 1974). Although a function describing this relationship (AMDVST) has been included in the model, it is not active in the nominal version (it has the value of 1) since by running the model it turned out not to be quantitatively important. Gross assimilation in milfoil tends to decrease from apex to stem base (Adams, Titus, and McCracken 1974). A function describing this relationship (REDFT) has been included in the model, but is not active in the nominal version (it has the value of 1) since it also turned out not to be quantitatively important.

A reduction factor, REDAM, can be used to take the effects of daily changes in $\mathrm{pH}$ and oxygen concentrations on AMX into account, by reducing the AMX by a factor between 0 and 1 for the whole day. REDAM currently has the value of 0.5 since it appears that $\mathrm{pH}$ in milfoil communities in Lake Wingra usually oscillates around 8.8 (Adams and McCracken 1974), causing a 50-percent reduction in photosynthetic activity (Titus and Stone 1982). Milfoil appears to be relatively insensitive to changes in oxygen concentration (a reduction in the net photosynthetic rate of only 5 percent was observed because of a change in oxygen concentration from 1 to 21 percent at $15 \mu \mathrm{m} \mathrm{CO}_{2}$; Van, Haller, and Bowes 1976).

A fitted, relative function, AMTMPT, describes the effect of daytime temperature on photosynthetic activity. This function has its optimum at $35{ }^{\circ} \mathrm{C}$ and is based on the photosynthetic response of milfoil to temperature (Titus and Adams 1979a; confirmed by Stanley and Nailor 1972; see Appendix C).

The instantaneous rate of gross assimilation over the height of the community is calculated by relating the assimilation rate per layer to the community-specific biomass distribution and by subsequent integration of all individually $0.1-\mathrm{m}$-high community layers.

The daily rate of gross assimilation is calculated by using the Gaussian integration method. This method specifies the discrete points at which the value of the function to be integrated has to be calculated and the weighting factors that must be applied to these values to attain minimum deviation from the analytical solution. A three-point method performs very well for calculating daily total assimilation (Goudriaan 1986; Spitters 1986). 


\section{Maintenance, growth, and assimilate partitioning}

Maintenance. Some of the carbohydrates formed are respired to provide energy for maintaining the existing plant components. The maintenance costs increase with metabolic activity, probably because of higher enzyme turnover and higher transport costs (Penning de Vries 1975).

The maintenance cost can be estimated from the chemical composition of the plant. Typical maintenance coefficients for various plant organs have been derived, based on numerous chemical determinations in agricultural crops. They typically range from 0.010 to $0.016 \mathrm{~g} \mathrm{CH}_{2} \mathrm{O} \mathrm{g} \mathrm{AFDW}{ }^{-1} \mathrm{~d}^{-1}$ (Penning de Vries and Van Laar 1982b).

In MILFO, the maintenance coefficients mentioned above are used to calculate the maintenance requirement of the plant cohorts. A lower maintenance coefficient of $0.005 \mathrm{~g} \mathrm{CH}_{2} \mathrm{O} \mathrm{g} \mathrm{AFDW}{ }^{-1}$ is used for the rhizome/root crown system, considered to be similar in respiration to stems with coefficients $<0.007$ (Penning de Vries et al. 1989a).

Higher temperatures expedite turnover rates of plant tissues and increase maintenance costs. A temperature increase of $10{ }^{\circ} \mathrm{C}$ usually increases maintenance respiration by a factor of about 2 up to temperatures that usually kill plants $\left(45\right.$ to $60{ }^{\circ} \mathrm{C} ; \mathrm{Q}_{10}=2$ at a reference temperature $30{ }^{\circ} \mathrm{C}$; Penning de Vries et al. 1989a).

Maintenance respiration in MILFO has been related to temperature by a factor, TEFF, which has the value of 1 between 5 and $20{ }^{\circ} \mathrm{C}$ (increases twofold with every $10{ }^{\circ} \mathrm{C}$ above a reference temperature of $20^{\circ} \mathrm{C}$ (Thornley and Johnson 1990a) and increases linearly from 0.0001 to 1 between 0 and $5{ }^{\circ} \mathrm{C}$ ). The value of 2 appears to be a reasonable average, but lower and higher $\mathrm{Q}_{10}$ values have been reported also (Amthor 1984). The currently used $Q_{10}$ value is lower in the 0 to $20{ }^{\circ} \mathrm{C}$ range than 2.28 found for a $\mathrm{Q}_{10}$ of dark respiration in milfoil (Grace and Wetzel 1978); however, the latter process includes growth processes.

Equations describing maintenance costs for milfoil plant cohorts $(1,2$, or 3$)$ are:

$$
\begin{aligned}
& \text { MAINTS }=0.016 \times T W L G+0.010 \times T W S G+0.015 \times T W R G \\
& \text { MAINT }=\text { MAINTS } \times \text { TEFF }
\end{aligned}
$$

where

$$
\begin{aligned}
\text { MAINTS }= & \text { maintenance respiration rate plant at reference temperature } \\
& \left(\mathrm{g} \mathrm{CH}_{2} \mathrm{O} \mathrm{m}^{-2} \mathrm{~d}^{-1}\right) \\
T W L G= & \text { total dry weight of live leaves }\left(\mathrm{g} \mathrm{DW} \mathrm{m}^{-2}\right)
\end{aligned}
$$




$$
\begin{aligned}
& T W S G=\text { total dry weight of live stems }\left(\mathrm{g} \mathrm{DW} \mathrm{m}^{-2}\right) \\
& T W R G=\text { total dry weight of roots }\left(\mathrm{g} \mathrm{DW} \mathrm{m}^{-2}\right)
\end{aligned}
$$

Equations describing maintenance costs for the rhizome/root crown system are:

$$
M A I N R T=0.005 \times T W G R I Z \times T E F F
$$

where

$$
\begin{aligned}
\text { MAINRT }= & \text { maintenance respiration rate rhizome/root crown system at } \\
& \text { reference temperature }\left(\mathrm{g} \mathrm{CH}_{2} \mathrm{O} \mathrm{m}^{-2} \mathrm{~d}^{-1}\right) \\
T W G R I Z= & \text { total dry weight of rhizome/root crown system of current day } \\
& (\mathrm{g} \mathrm{DW} \mathrm{m})
\end{aligned}
$$

Growth. Assimilates in excess of maintenance costs are available for conversion into structural plant material. In this conversion process of the glucose molecule, $\mathrm{CO}_{2}$ and $\mathrm{H}_{2} \mathrm{O}$ are released. The assimilates required to produce one unit weight of any particular plant organ can be calculated from its chemical composition and the assimilate requirements of the various chemical components. Typical values are $1.46 \mathrm{~g} \mathrm{CH}_{2} \mathrm{O} \mathrm{g} \mathrm{DW}{ }^{-1}$ for leaves, 1.51 for stems, and 1.44 for roots (Penning de Vries and Van Laar 1982b; Penning de Vries et al. 1989a), confirmed by Griffin (1994). At higher temperatures, the conversion processes are accelerated, but the pathways are identical. The recently determined construction costs for several submersed plant species, using a different method (Williams et al. 1987), are generally lower, ranging from 0.99 to 1.11 (Spencer, Ryan, and Ksander 1997). However, the latter plants appear to be relatively poor in nitrogen, and transport costs have not been included, both factors that may have contributed to this lower cost calculated.

In MILFO, the construction costs typical for agricultural plants have been used since construction costs calculated for milfoil shoots with an average chemical composition were similar to those in agricultural plants, i.e., $1.54 \mathrm{CH}_{2} \mathrm{O} \mathrm{g}$ $\mathrm{DW}^{-1}$ (see Appendix C).

The following equation describes growth:

$$
G T W=\frac{((R E M O B 1 \times C V T)+G P H O T-T R A N S 1-M A I N T)}{A S R Q}
$$

where

$$
\begin{aligned}
G T W= & \text { dry matter growth rate of vegetation (plants excluding } \\
& \text { rhizome/root crown system; } \left.\mathrm{g} \mathrm{DW} \mathrm{m}^{-2} \mathrm{~d}^{-1}\right) \\
G P H O T= & \text { daily total gross assimilation rate of community }\left(\mathrm{g} \mathrm{CH}_{2} \mathrm{O} \mathrm{m}^{-2} \mathrm{~d}^{-1}\right) \\
R E M O B 1= & \text { remobilization rate of carbohydrates cohort } 1\left(\mathrm{~g} \mathrm{CH}_{2} \mathrm{O} \mathrm{m}^{-2} \mathrm{~d}^{-1}\right)
\end{aligned}
$$




$$
\begin{aligned}
\text { TRANS1 }= & \text { translocation rate of carbohydrates cohort } 1\left(\mathrm{~g} \mathrm{CH}_{2} \mathrm{O} \mathrm{m}^{-2} \mathrm{~d}^{-1}\right) \\
\text { MAINT }= & \text { maintenance respiration rate of vegetation }\left(\mathrm{g} \mathrm{CH}_{2} \mathrm{O} \mathrm{m}^{-2} \mathrm{~d}^{-1}\right) \\
A S R Q= & \text { assimilate requirement for plant dry matter production }\left(\mathrm{g} \mathrm{CH}_{2} \mathrm{O}\right. \\
& \left.\mathrm{g} \mathrm{DW}^{-1}\right)
\end{aligned}
$$

Assimilate partitioning. Assimilate partitioning is the process by which assimilates available for growth are allocated to leaves, stems, roots, and/or storage organs. The distribution pattern is a function of physiological age.

In MILFO, the assimilate allocation pattern has been used synonymously with the biomass allocation pattern. This pattern is assumed to be followed after the shoot tips have reached the water surface and not to change with physiological age (only summer values on biomass partitioning were available). The assimilate allocation has been set at 0.47 of total net growth (excluding rhizome/root crown system) to leaves, 0.47 to stems, and 0.06 to roots. These values have been derived from the compartmentalization of biomass over plant organs in a well-developed milfoil community, with shoots composed of 50 percent by leaves and 50 percent by stems (Budd, Lillie, and Rasmussen 1995). A contribution of 0.06 to total biomass by roots was chosen since no information on the roots of the same vegetation was given, but root biomass is known to be usually small (similar to the contribution of roots to total plant biomass in hydrilla; Best and Boyd 1996). Contributions of leaves and stems to total biomass were recalculated proportionally.

The following equation describes biomass allocation to plant organs:

$$
\begin{aligned}
& G R T=F R T \times G T W \\
& G S T=F S T \times G T W \\
& G L V=F L V \times G T W
\end{aligned}
$$

where

$G R T, G S T$, and $G L V=$ dry matter growth rates of roots, stems, and leaves, respectively $\left(\mathrm{g} \mathrm{DW} \mathrm{m}^{-2} \mathrm{~d}^{-1}\right)$

$F R T, F S T$, and $F L V=$ fraction of total dry matter allocated to roots, stems, and leaves, respectively (relative)

$$
\begin{aligned}
& G T W=\text { dry matter growth rate of the vegetation (plants } \\
& \text { excluding rhizome/root crown system; } g \text { DW } \mathrm{m}^{-2} \mathrm{~d}^{-1} \text { ) }
\end{aligned}
$$

In adolescent milfoil plants, shoot biomass is usually present for 61 percent in the upper $0.5-\mathrm{m}$ water column, distributed for 10 percent in the upper $0.1-\mathrm{m}$ layer, for 16 and 17 percent in both successive layers 2 and 3, and for 10 and 8 percent in both successive layers 4 and 5 (Adams, Titus, and McCracken 
1974). These values form the basis for the dry matter allocation per depth layer over the vertical axis, from water surface to $0.5-\mathrm{m}$ depth. The values of this function (DMPC) are read from the input file and can be changed by the user. Dry matter allocation to the lower water layers is equal up to a total biomass share of 5 percent. The remaining biomass is divided proportionally over all water layers. Vertical biomass distribution pattern is recalculated and redistributed by MILFO when a rooting depth other than the nominal one $(1.5 \mathrm{~m})$ is chosen.

A relational diagram illustrating photosynthesis, respiration, and biomass formation of milfoil is shown in Figure 3.

\section{Flowering, Translocation, and Senescence}

The occurrence of flowering affects subsequent metabolic activity of the vegetation. The timing of flowering is, therefore, extremely important for the physiological activity and biomass formation, while the actual investment of dry matter in flowers and seeds proves to be only minor (Madsen 1997).

After flowering, scenescence sets in, and a considerable part of net production is translocated downwards to the rhizome/root crown system, while the remainder of net production is allocated according to the above-mentioned key.

The translocated material consists mainly of carbohydrates and proteins and is largely equivalent with starch (Gijzen 1985). Conversion of starch to glucose increases the dry matter with a factor 10/9, whereas the transport of glucose costs dry matter, i.e., $36 / 38$. Thus, the total transport "cost" of downward translocation is a factor CVT $=1.05(10 / 9 \times 36 / 38)$. Measured data on translocation are extremely scarce for terrestrial plants and absent for aquatic plants. Translocation proved to be 29 percent of net production in cassava (Gijzen 1985) and 35 percent in certain potato varieties (Kooman 1996). Estimates of translocation in submersed plants vary from 19 percent of net production in sea grasses (Wetzel and Neckles 1996) to about 40 percent in hydrilla (Best and Boyd 1996).

In MILFO, TRANS follows a hyperbolic relationship initially set to 35 percent (TRAFAC) of net production by the senescing plant cohort, multiplied by CVT, and decreasing exponentially to zero with concomitantly decreasing biomass of the translocating plant cohort and increasing biomass of the successive growing plant cohort.

Translocation is described by the following equation:

$$
\begin{aligned}
\text { TRANS1 }= & C V T \times G P H O T \times((T W L G 2+T W S G 2+T W R G 2) / \\
& (T W L G 1+T W S G 1+T W R G 1+T W L G 2+T W S G 2+T W R G 2)) \times \\
& \text { TRAFAC }
\end{aligned}
$$




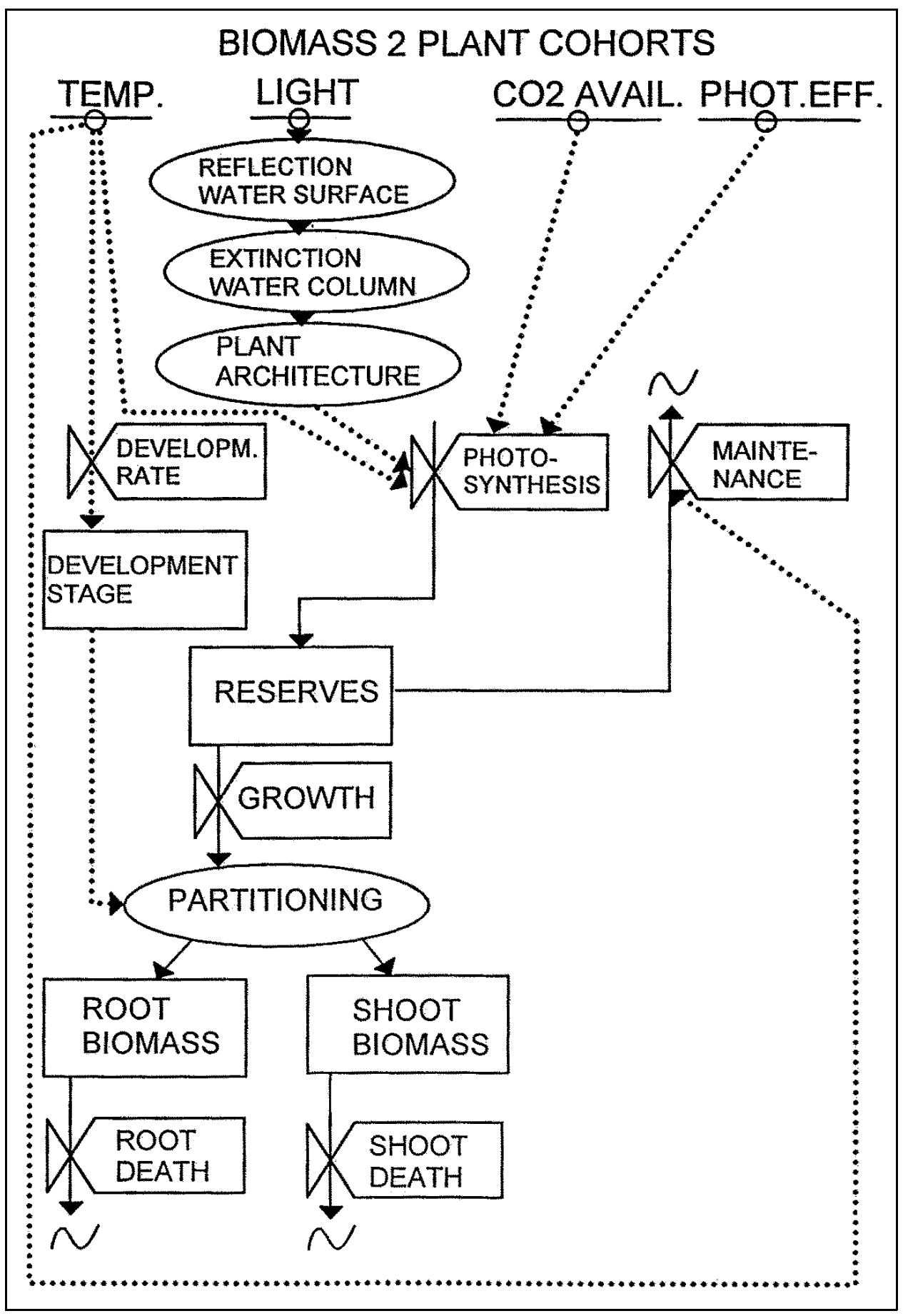

Figure 3. Relational diagram illustrating photosynthesis, respiration, and biomass formation in milfoil 
where

$$
\begin{aligned}
\text { TRANS } 1= & \text { translocation rate cohort } 1\left(\mathrm{~g} \mathrm{CH}_{2} \mathrm{O} \mathrm{m}^{-2} \mathrm{~d}^{-1}\right) \\
C V T= & \text { conversion/transport factor (relative) } \\
\text { GPHOT }= & \text { daily total gross } \mathrm{CH}_{2} \mathrm{O} \text { assimilation rate of community } \\
& \left(\mathrm{g} \mathrm{CH}_{2} \mathrm{O} \mathrm{m}^{-2} \mathrm{~d}^{-1}\right)
\end{aligned}
$$

$T W L G 1$ or $2=$ total weight of green leaves cohort 1 or cohort $2\left(\mathrm{~g} \mathrm{DW} \mathrm{m}^{-2}\right)$

TWSG1 or $2=$ total weight of green stems cohort 1 or cohort $2\left(\mathrm{~g} \mathrm{DW} \mathrm{m}^{-2}\right)$

$T W R G 1$ or $2=$ total weight of live roots cohort 1 or cohort $2\left(\mathrm{~g} \mathrm{DW} \mathrm{m}^{-2}\right)$

$$
\text { TRAFAC }=\text { translocation factor (relative) }
$$

Senescence refers to the loss of capacity to carry out essential physiological processes and to the loss of biomass. The fundamental processes involve physiological aging and protein (enzyme) breakdown. These processes are difficult to quantify. It is known that hormones are important messengers in this context, but not how they precisely act. High temperature usually accelerates senescence.

In MILFO, a mechanistic approach to senescence has been chosen by setting the death rate at a certain fraction of plant biomass lost per day once the conditions for growth deteriorate. The timing and value of relative death rate (RDR) of plant cohorts 1 and 2 have been derived from field observations on shoot biomass in Lake Wingra, Wisconsin (Adams and McCracken 1974). For plant cohort 3, timing and relative death rate of the plant cohorts 1 and 2 performed well, and length of the third senescence period turned out to be similar to that of plant cohort 2.

The timing of onset of senescence was found by running the model repeatedly with different development rates, base and reference temperatures. Thus, initiation of senescence for cohort 1 was set at DVS 1.631, for cohort 2 at DVS 2.001, and for cohort 3 at 3.501 .

The value for the relative death rate of the plants was found by applying the same differential equation as commonly used for simple exponential growth, to describe exponential decrease in biomass after flowering, with a negative specific decrease rate (Thornley and Johnson 1990b; Hunt 1982). An RDR of $0.042 \mathrm{~d}^{-1}$ was calculated following this approach.

The value for the relative death rate of the rhizome/root crown system was set at $0.00042 \mathrm{~d}^{-1}$ as described in the section Wintering and Sprouting of Rhizomes/ Root Crowns and Growth of Sprouts to Water Surface. 
A relational diagram illustrating translocation and senescence is shown in Figure 4.

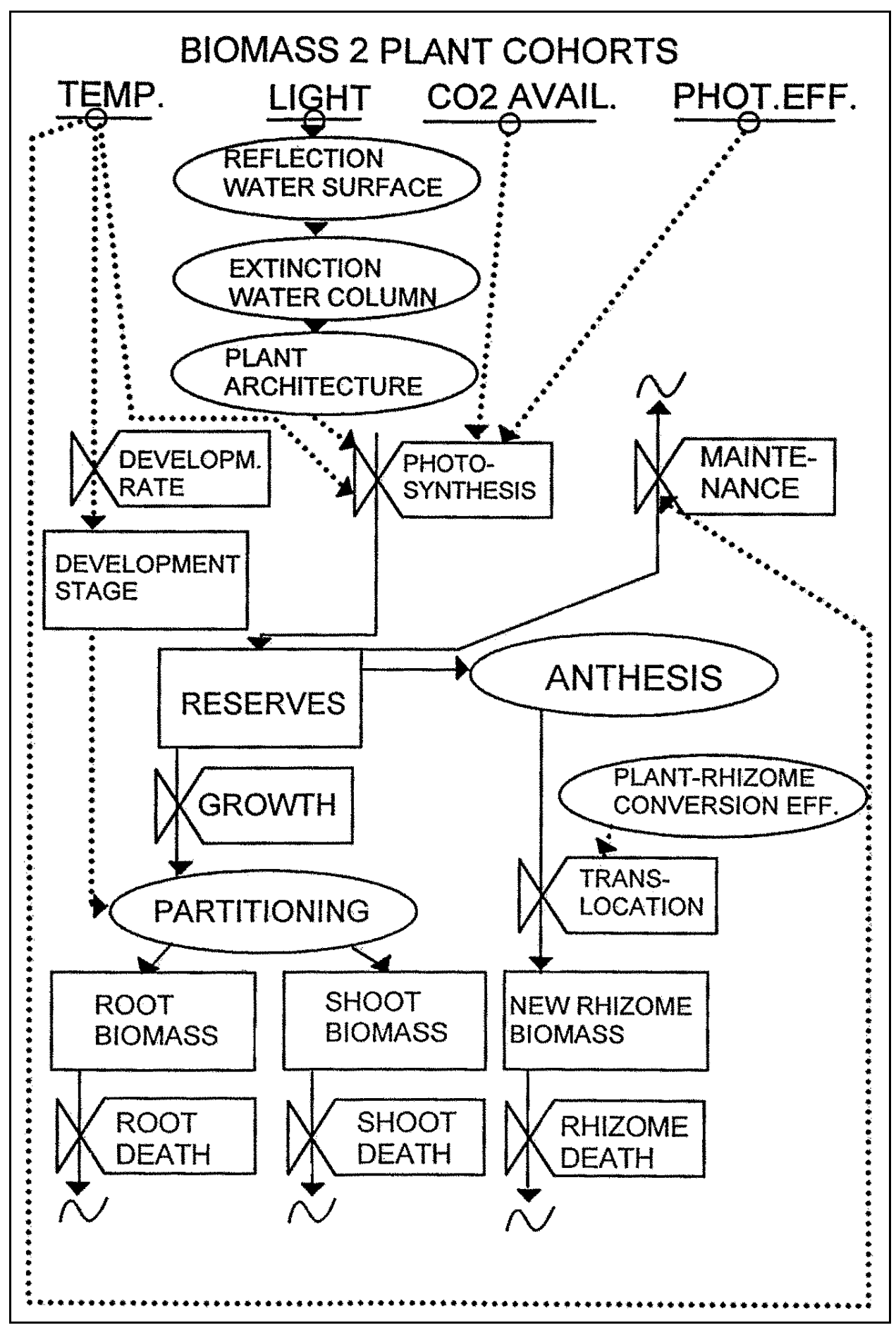

Figure 4. Relational diagram illustrating translocation and senescence following anthesis in milfoil 


\section{Choice of Parameter Values}

A relatively simple simulation model like MILFO includes parameter values that can be defined with varying certainty. Most parameters have been calculated/estimated from published literature (Table 3). Only development rate in relation to $3{ }^{\circ} \mathrm{C}$ day-degree sum and base temperature have been calibrated by running the model. The choice of parameter values has been detailed in the preceding sections of this chapter. 


\begin{tabular}{|c|c|c|c|}
\hline \multicolumn{4}{|l|}{$\begin{array}{l}\text { Table } 3 \\
\text { Parameter Values Used in MILFO }\end{array}$} \\
\hline Parameter & Abbreviation & Value & Reference \\
\hline \multicolumn{4}{|c|}{ Morphology, Phenological Cycle, and Development } \\
\hline First Julian day number & DAYEM & 1 & \\
\hline Development rate as function of temperature & $\operatorname{DVR}(T)^{*}$ & $0.015-0.022$ & Calibrated \\
\hline Base temperature for juvenile plant growth & TBASE & $3^{\circ} \mathrm{C}$ & Calibrated \\
\hline \multicolumn{4}{|c|}{ Maximum Biomass and Plant Density } \\
\hline Maximum biomass & AMIN1 TGW & $2,283 \mathrm{~g} \mathrm{DW} \mathrm{m}^{-2}$ & 4 \\
\hline Plant density & NPL & $11 \mathrm{~m}^{-2}$ & 4 \\
\hline \multicolumn{4}{|c|}{ Wintering and Sprouting of Rhizomes/Root Crowns and Growth of Sprouts to Water Surface } \\
\hline Critical rhizome weight & CRRIZ & $12 \mathrm{~g} \mathrm{DW} \mathrm{m}^{-2}$ & 8 \\
\hline Initial rhizome weight & IWGRIZ & $50 \mathrm{~g} \mathrm{DW} \mathrm{m}^{-2}$ & 10 \\
\hline Relation coefficient rhizome/root crown weight-stem length & RCSHST & $12 \mathrm{~m} \mathrm{~g} \mathrm{DW}^{-1}$ & 3,17 \\
\hline Relative death rate of rhizomes & RDRIZ & $0.00042 \mathrm{~d}^{-1}$ & 18 \\
\hline Relative conversion rate of rhizome/root crown weight into plant material & ROC & $\begin{array}{l}0.0576 \mathrm{~g} \mathrm{CH}_{2} \mathrm{O} . \\
\mathrm{g} \mathrm{DW}^{-1} \mathrm{~d}^{-1}\end{array}$ & 3 \\
\hline \multicolumn{4}{|c|}{ Light and Photosynthesis of Plants } \\
\hline Daytime temperature effect on AMX as function of DVS & $\operatorname{AMTMP}(\mathrm{T})$ & $0-1$ & 13,11 \\
\hline Potential $\mathrm{CO}_{2}$ assimilation rate at light saturation for shoot tips & AMX & $\begin{array}{l}0.0165 \mathrm{~g} \mathrm{CO}_{2} \\
\mathrm{~g} \mathrm{DW}^{-1} \mathrm{~h}^{-1}\end{array}$ & 2,16 \\
\hline Conversion factor for translocated dry matter into $\mathrm{CH}_{2} \mathrm{O}$ & CVT & 1.05 & 9 \\
\hline Initial light-use efficiency for shoot tips & EE & $0.000011 \mathrm{~g} \mathrm{CO}_{2} \mathrm{~J}^{-1}$ & 9 \\
\hline Reflection coefficient of irradiance at water surface & $\mathrm{RC}$ & 0.06 & 5 \\
\hline Reduction factor to relate AMX to water $\mathrm{pH}$ & REDAM & 0.5 & 7,15 \\
\hline $\begin{array}{l}\text { Reduction factor for } \mathrm{AMX} \text { to account for senescence plant parts over } \\
\text { vertical vegetation axis }\end{array}$ & REDF(T) & 1.0 & User def. \\
\hline Plant species specific light-extinction coefficient & $\mathrm{K}(\mathrm{T})$ & $0.006 \mathrm{~m}^{2} \mathrm{~g} \mathrm{DW}^{-1}$ & 13 \\
\hline Water type specific light-extinction coefficient & $\mathrm{L}(\mathrm{T})$ & $1.15-2.00 \mathrm{~m}^{-1}$ & 7 \\
\hline Thickness per plant layer & TL & $0.1 \mathrm{~m}$ & 14 \\
\hline \multicolumn{4}{|c|}{ Maintenance, Growth, and Assimilate Partitioning of Plants } \\
\hline Dry matter allocation to each plant layer & $\mathrm{DMPC}(\mathrm{T})$ & $0-1$ & 1 \\
\hline Leaf dry matter allocation to each plant layer & $\mathrm{FL}(\mathrm{T})$ & 0.50 & 1 \\
\hline Fraction of total dry matter increase allocated to leaves & $\operatorname{FLV}(\mathrm{T})$ & 0.47 & 1 \\
\hline Fraction of total dry matter increase allocated to roots & $\mathrm{FRT}(\mathrm{T})$ & 0.06 & 1 \\
\hline Fraction of total dry matter increase allocated to stems & $\mathrm{FST}(\mathrm{T})$ & 0.47 & 1 \\
\hline $\begin{array}{l}\text { Factor accounting for effect of daily effective temperature on maintenance } \\
\text { respiration }\end{array}$ & TEFF(T) & $0-12$ & 12 \\
\hline
\end{tabular}




\begin{tabular}{|c|c|c|c|}
\hline \multicolumn{4}{|l|}{ Table 3 (Concluded) } \\
\hline Parameter & Abbreviation & Value & Reference \\
\hline \multicolumn{4}{|c|}{ Flowering, Translocation, and Senescence } \\
\hline Relative death rate of leaves (on DW basis) & $\operatorname{RDR}(\mathrm{T})$ & $0.042 \mathrm{~d}^{-1}$ & 2 \\
\hline Relative death rate of stems and roots (on DW basis) & $\operatorname{RDS}(\mathrm{T})$ & $0.042 \mathrm{~d}^{-1}$ & 2 \\
\hline Translocation (part of net photosynthetic rate) & TRAFAC & 0.35 & 5 \\
\hline \multicolumn{4}{|c|}{ Site Information } \\
\hline Lag period between water and air temperature & DELAY & $7 d$ & User def. \\
\hline Water depth (= rooting depth) & DEPTH & $1.5 \mathrm{~m}$ & User def. \\
\hline Total live dry weight measured (field site) & $\operatorname{TGWM}(T)$ &,$- \mathrm{g} \mathrm{DM} \mathrm{m}^{-2}$ & User def. \\
\hline Daily water temperature (field site) & WTMP $(T)$ &,$-{ }^{\circ} \mathrm{C}$ & User def. \\
\hline \multicolumn{4}{|c|}{ Harvesting } \\
\hline Harvesting & HAR & 0 or 1 & User def. \\
\hline Harvesting day number & HARDAY & $1-365$ & User def. \\
\hline Harvesting depth (measured from water surface in $\mathrm{m}$ ) & HARDEP & $0.1 \mathrm{~m}<\mathrm{DEPTH}$ & User def. \\
\hline \multicolumn{4}{|c|}{$\begin{array}{l}\text { Notes: 1. Adams, Titus, and McCracken 1974; } 2 \text {. Adams and McCracken 1974; 3. Bowes, Holaday, and Haller 1979; 4. Budd, } \\
\text { Lillie, and Rasmussen 1995; 5. Golterman 1975; 6. Kooman 1995; 7. Lee and Kluesener 1972; 8. Madsen 1997; 9. Penning de } \\
\text { Vries and Van Laar 1982a, b; 10. Smith and Adams1986; 11. Stanley and Nailor 1972; 12. Thornley and Johnson 1990a; 13. } \\
\text { Titus and Adams 1979a; 14. Titus et al. 1975; 15. Titus and Stone 1982; 16. Van, Haller, and Bowes 1976; 17. Van der Zweerde } \\
\text { 1981; 18. Vogt, Vogt, and Bloomfield 1991. *, Calibration function. }\end{array}$} \\
\hline
\end{tabular}




\section{Performance Tests}

\section{Simulated and Measured Behavior of a Milfoil Community in Lake Wingra, Wisconsin}

\section{Nominal run}

The seasonal changes in biomass of plant shoots and roots and of the rhizome/root crown system as simulated by MILFO are shown in Figure 5A and B. Simulated shoot biomass compared well with shoot biomass measured in Lake Wingra (Figure 5C). Peak biomass appeared to be reached somewhat earlier in the simulation than found in the lake; however, the latter may be due to the low frequency of field observations (no measurements between September and November). The simulated biomass of the rhizome/root crown system showed two maxima per year. Variation was within the range found in a milfoil community in the same lake in later years (Smith and Adams 1986).

Simulated transport of carbohydrates was substantial in the beginning and at the end of the growing period of each plant cohort, when carbohydrate remobilization from the rhizome/root crown system supports growth of the sprouts, and carbohydrate translocation from plant organs supports the filling of the rhizome/ root crown system, respectively (Figure 6). Carbohydrate transport could be in the same range as net assimilation at the beginning and end of the growth season (Figure 7). Maintenance respiration was usually considerably lower than assimilation as well as carbohydrate transport, as can be expected at the relatively low water temperatures (Figure 7).

Running the model with the low assimilate requirements suggested to be typical for submersed aquatic vegetation by Spencer, Ryan, and Ksander (1997) showed that peak biomass of milfoil shoots would increase by a factor of 2 , oscillations in biomass of the rhizome/root crown system would be greater, and final biomass of the rhizome/root crown system would be increased (Figure 8). However, as indicated in Chapter 3, the opinion of these authors is that a construction cost of 0.99 to 1.11 for milfoil plant tissues is on the low side, taking the usually high $\mathrm{N}$ concentrations of shoots into consideration. 


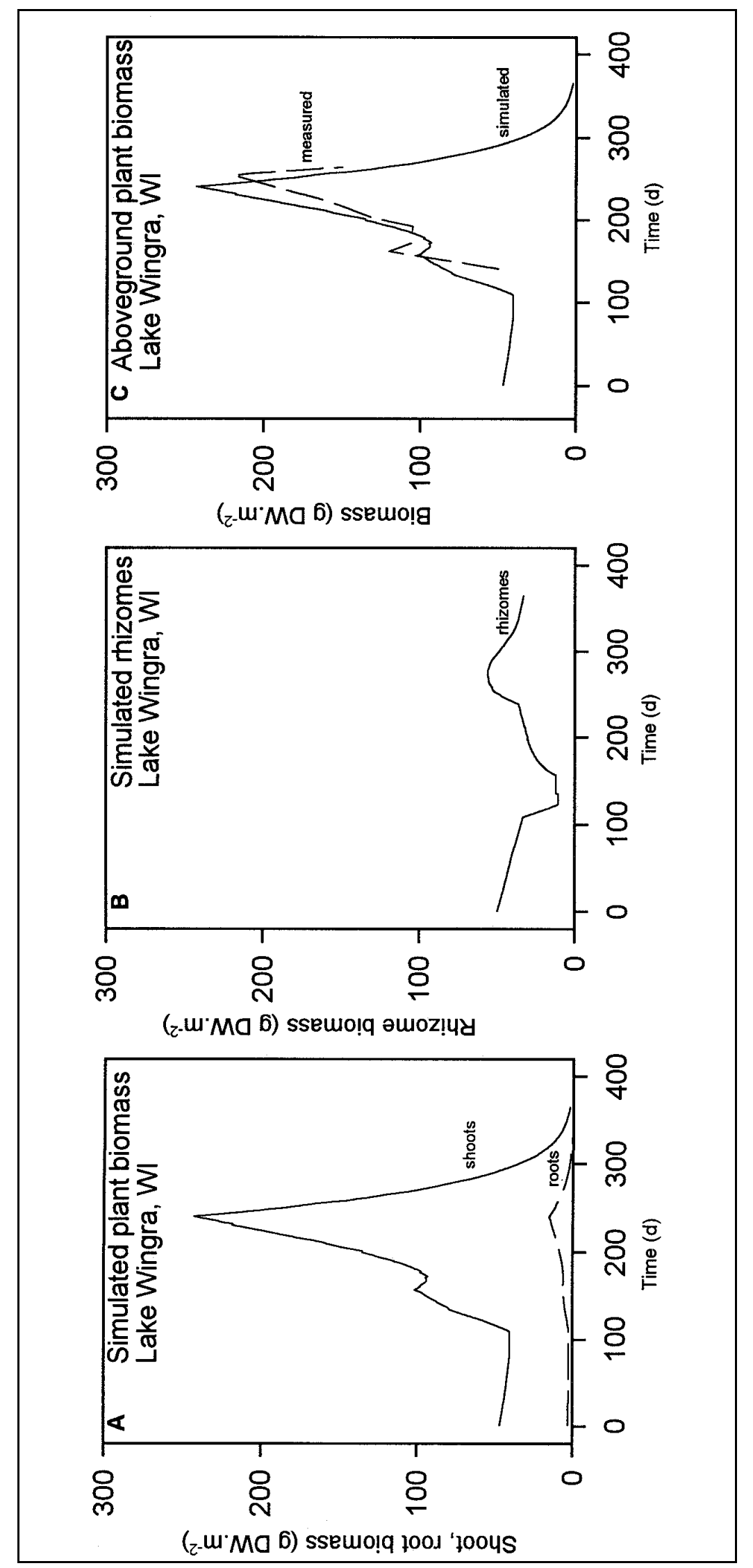

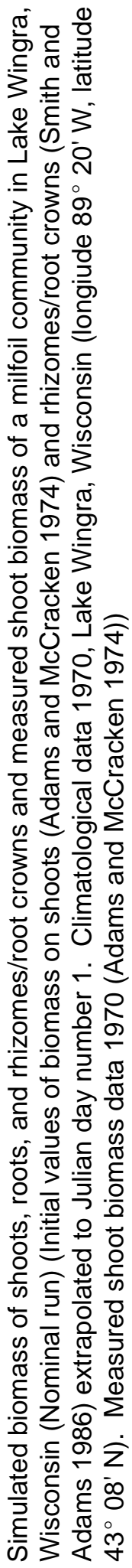

눈 


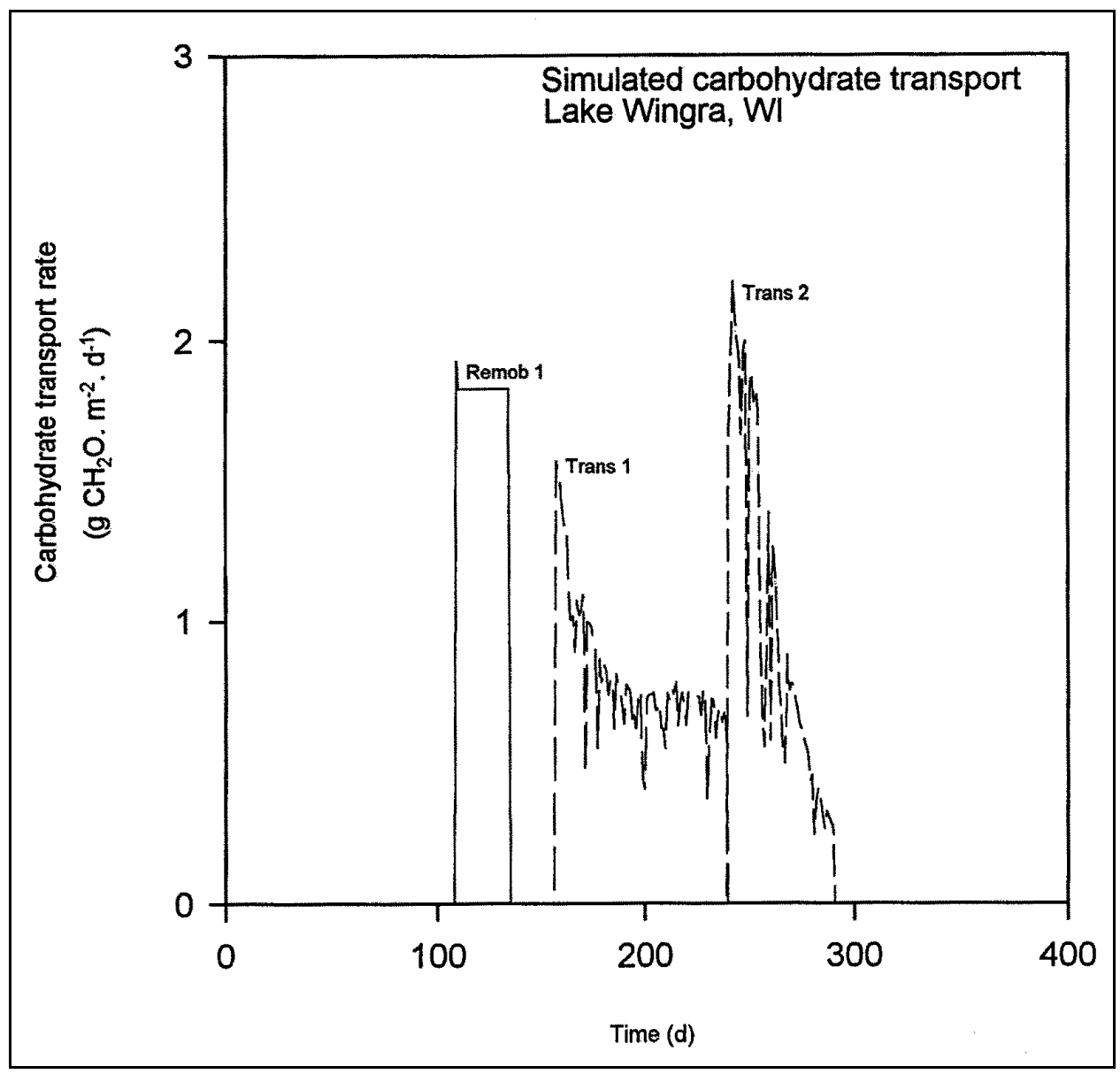

Figure 6. Simulated behavior of carbohydrate flow through plant compartments (Carbohydrate remobilization and upward transport from rhizomes/ root crowns are used for initial growth of each plant cohort. DownWard carbohydrate translocation into rhizomes/root crowns occurs during anthesis and senescence of each plant cohort (Initial biomass and climatological data as in nominal run))

Running the model for the same year and lake, but with only rhizomes/root crowns initially present (Figure 9B), showed that plant biomass of both cohorts was greatly reduced and critical weight of the rhizome/root crown system was reached more often than with initial plant biomass present (Figure 9A; nominal run). This large difference in peak biomass is due to the inability of the plant community to fully capture the high spring irradiance at this latitude of $43{ }^{\circ} \mathrm{N}$ without wintering shoots. Thus, wintering shoots provide a distinct advantage for this plant species.

Running the model with (24-hr average) air temperatures lagging 7 days behind water temperatures or measured water temperatures as forcing variables yielded similar biomass values, despite the fact that instantaneous assimilation rates varied less with water temperatures than with air temperatures, and assimilation rates had shifted somewhat in time (Figure 10). This illustrates the 


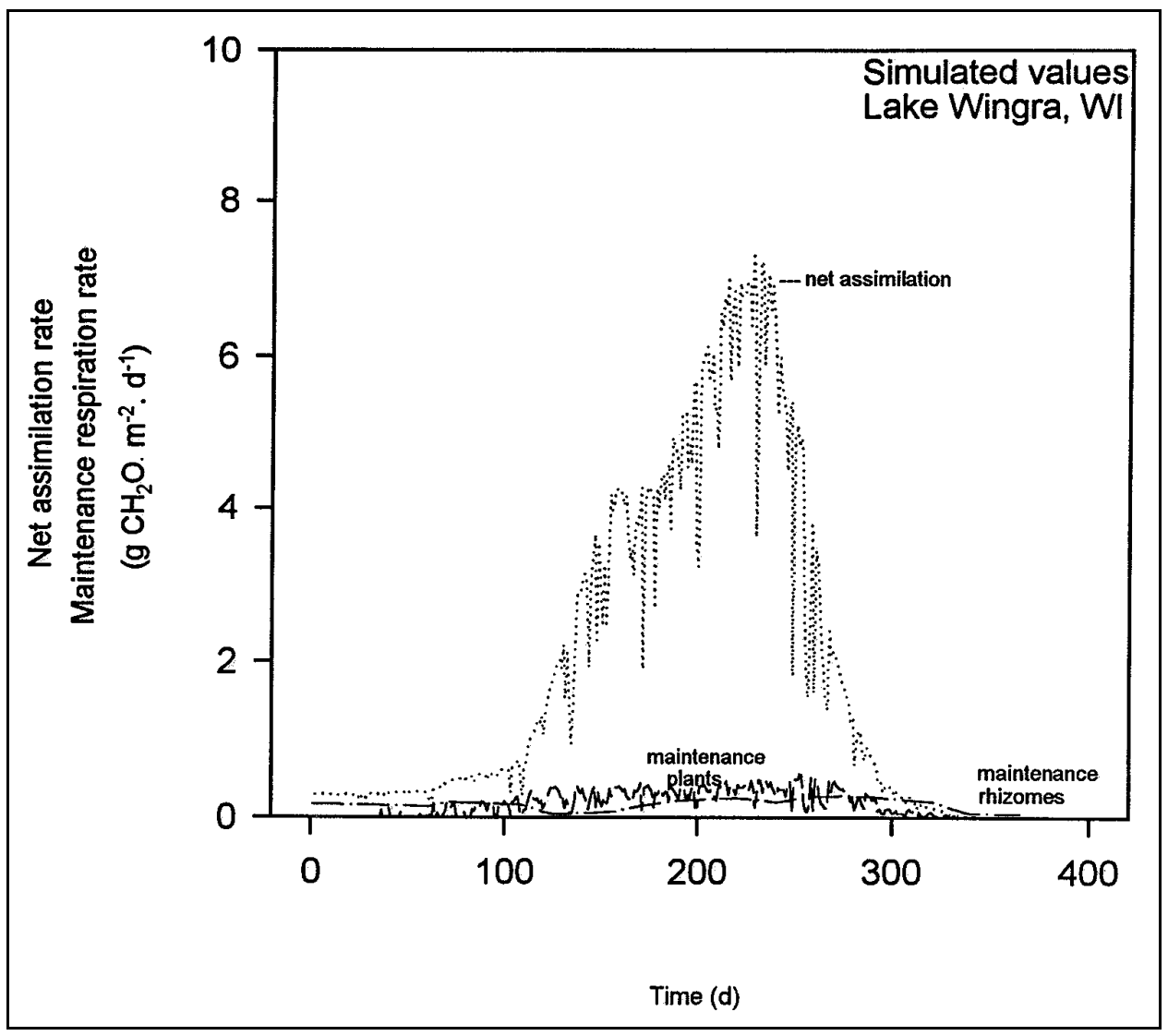

Figure 7. Simulated rates of daily net assimilation and maintenance respiration of a milfoil community in Lake Wingra, Wisconsin (Initial biomass and climatological data as in nominal run)

usefulness of inclusion of both temperature options in the model, facilitating use of the model by users who do not possess a full data set of water temperatures for the water body for which they desire to run the model. It has to be cautioned, however, that the relationship between the temperatures of air and of each water body concerned may differ since temperatures within each water body are influenced by catchment morphometry, wind speed, fetch, mixing processes, and upward seepage, etc. In the experience of these authors, however, a lag period of 7 days between air and water temperatures usually described this relationship well for shallow water bodies (up to 5-6 m), without large inflows of groundwater.

\section{Effects of year-to-year differences in climate}

The model was run with initial biomass values and local climatological data as inputs for a different year, 1972 (Figure 11). A run with water temperatures of a previous (1970) year yielded less biomass (Figure 11A) than actually measured (Figure 11C). A run with air temperatures of 1972, in contrast, yielded less biomass for the first plant cohort, but similar biomass as measured for the 

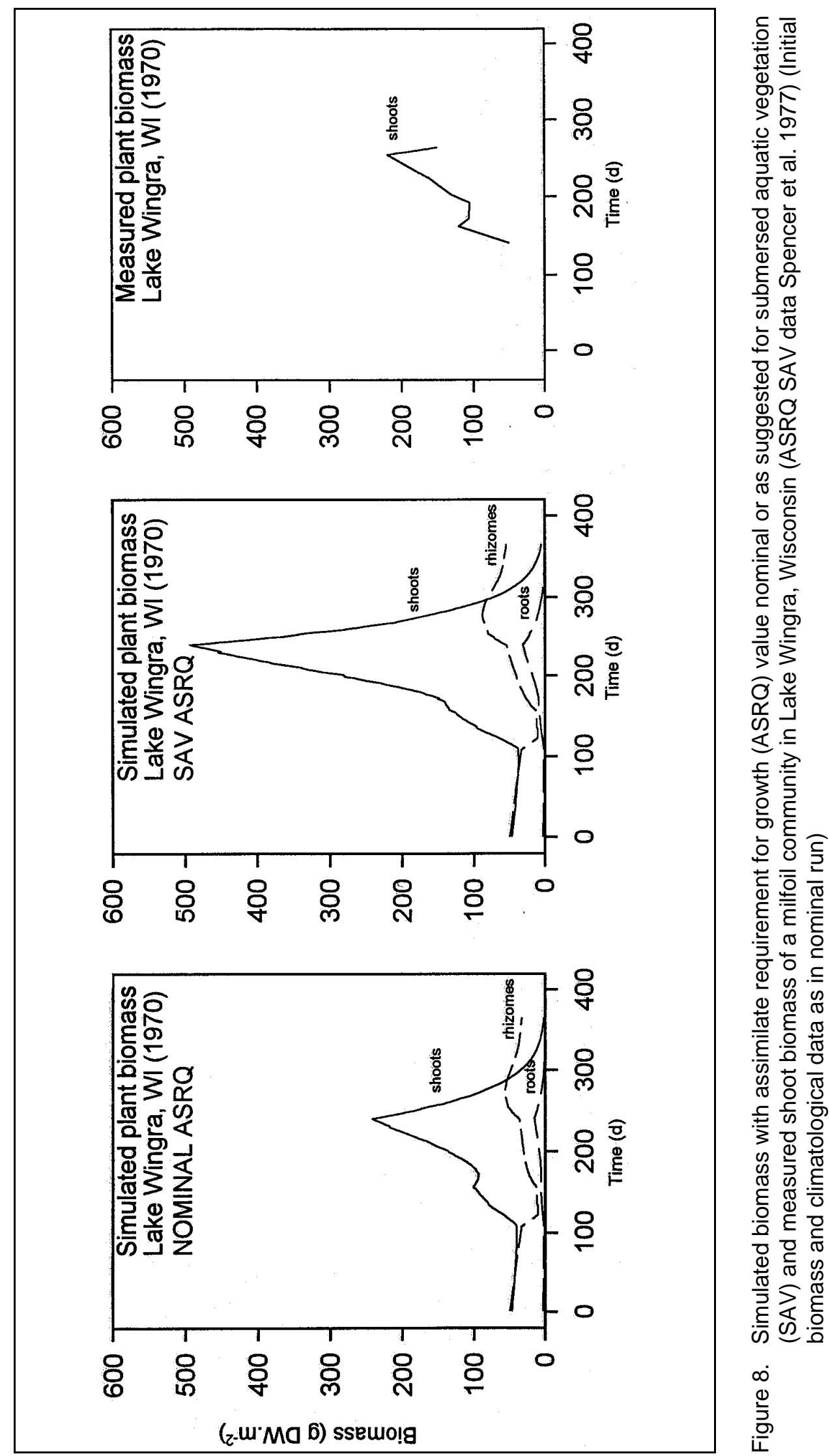

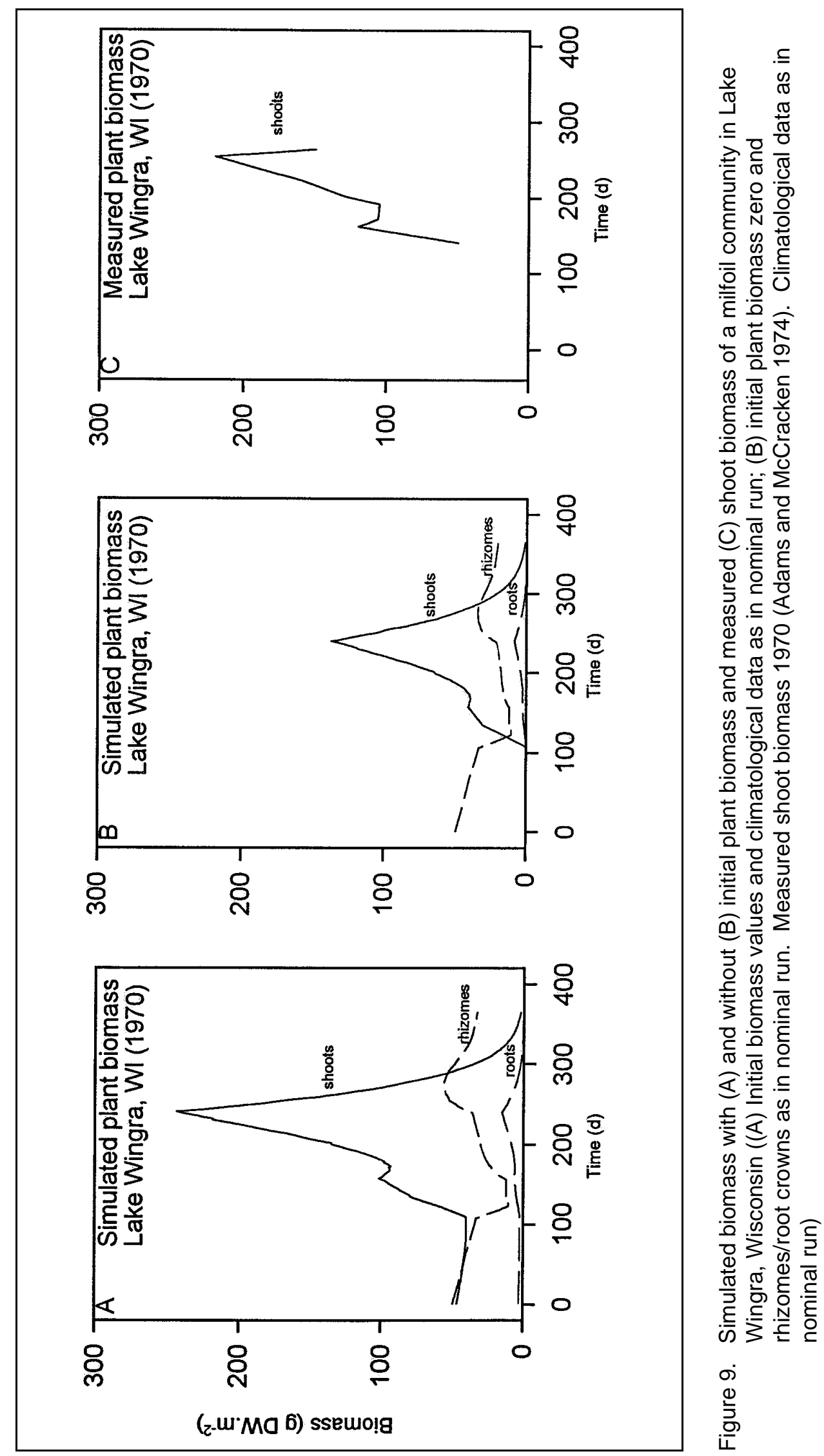


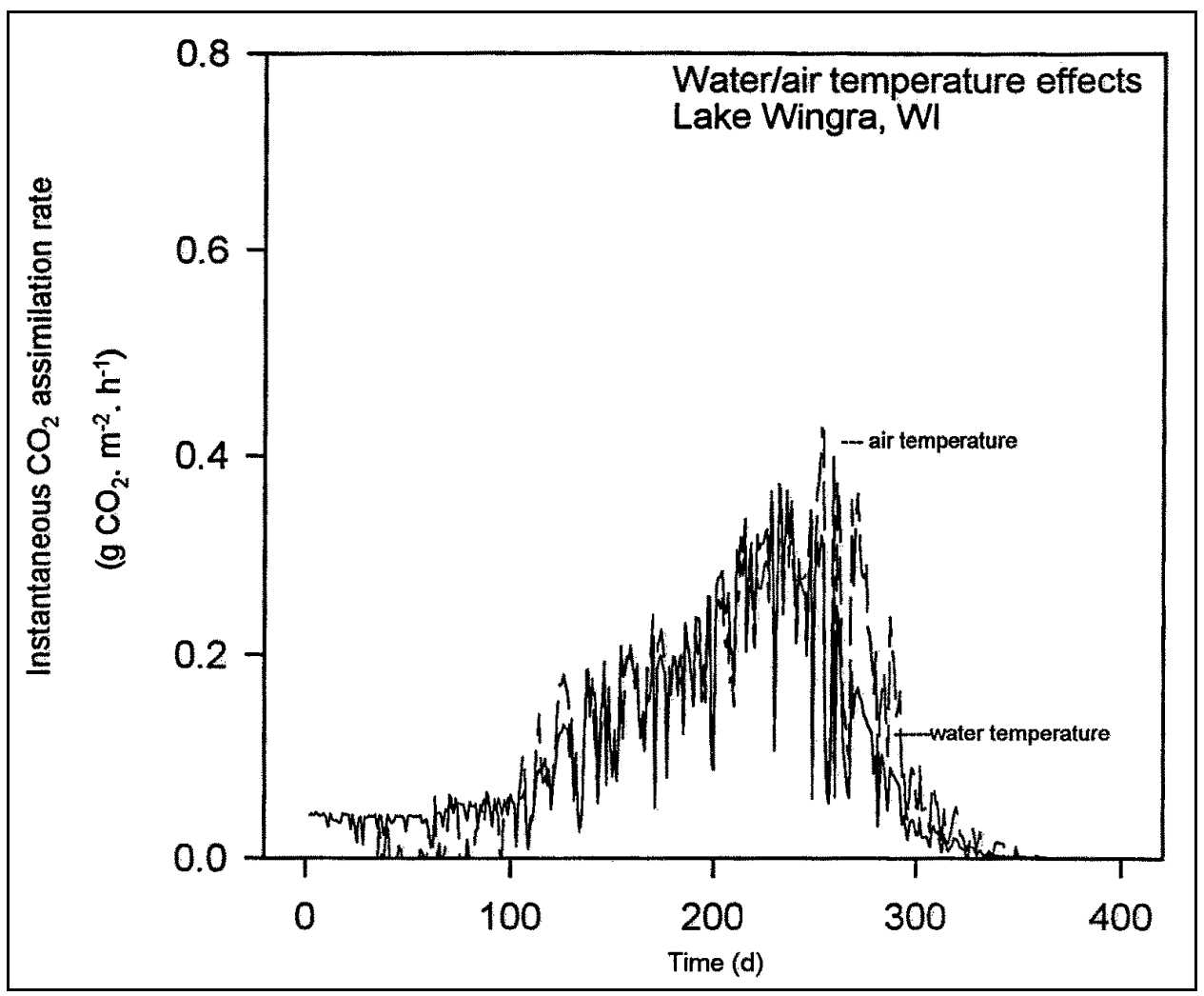

Figure 10. Simulated photosynthetic rates of a milfoil community in Lake Wingra, Wisconsin, with water or air temperatures as input (Initial biomass and climatological data as in nominal run)

second cohort (Figure 11B). However, irradiances in both years, 1970 and 1972, differed in that total irradiance and, consequently, temperature sum were higher in 1970 than in 1972 (particularly in spring), and, thus, higher biomass production was to be expected using water temperatures of 1970. This leads one to believe that the early peak biomass value measured in 1972 is an overestimate. The latter suggestion is supported by the fact that the measured biomass level could neither be attained by running the model with considerably decreased light-extinction coefficients tentatively indicative for the clear water phase in spring, which is typical for this lake.

\section{Simulated and Measured Behavior of a Milfoil Community at Other Latitudes}

To investigate whether the model was able to simulate behavior of a milfoil community at other sites, runs were made for a site at a more southern latitude, Lake Guntersville, Alabama. Behavior of milfoil in this lake is particularly interesting because the lake is long, oriented from north-east to south-west, and situated at a latitude around $34^{\circ} \mathrm{N}$, being very close to tropical $\left(33^{\circ} \mathrm{N}\right)$. Biomass of milfoil communities in this lake has been described as having a high 


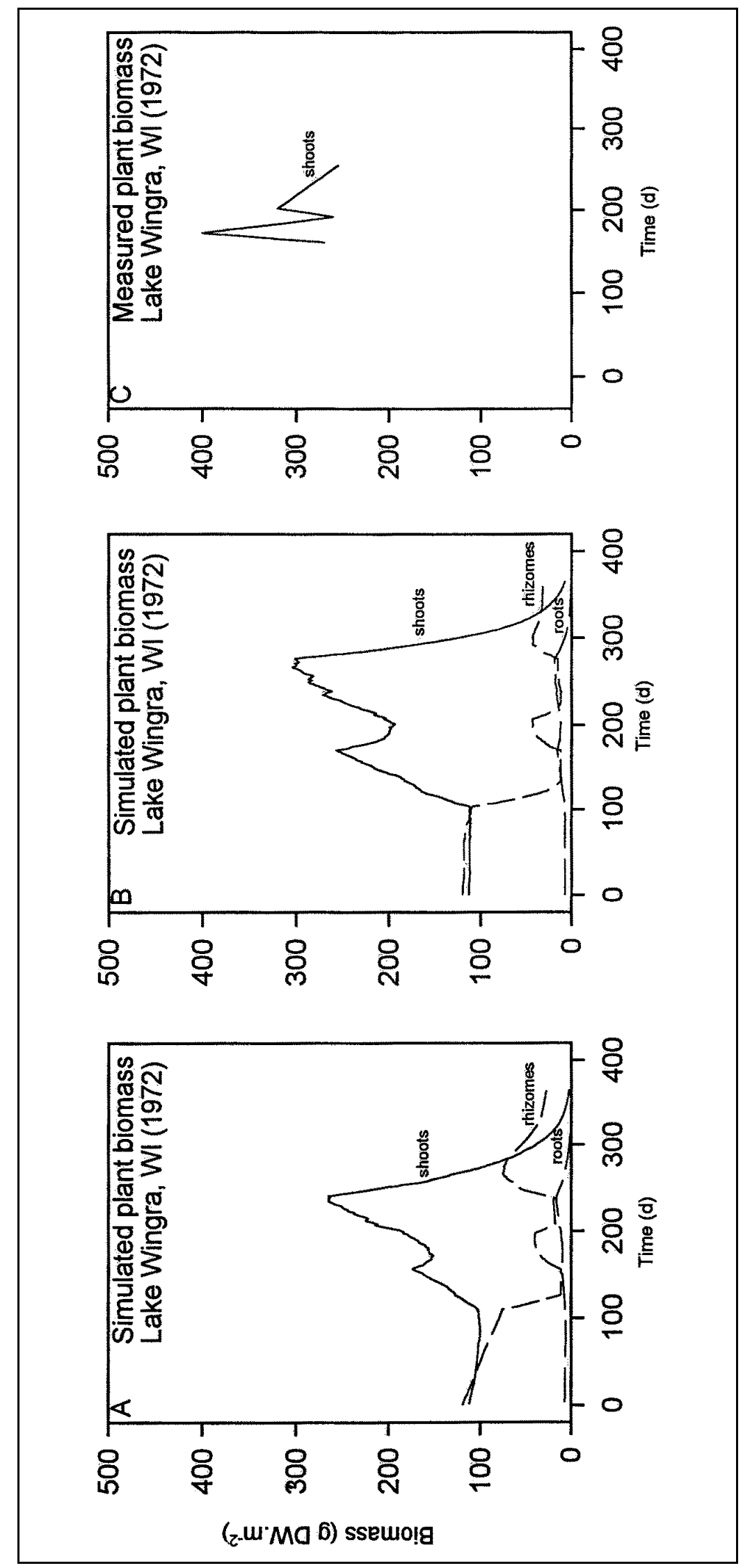

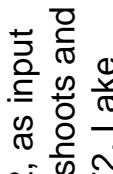

ำ

O

产苋 贾

응 음

으음

ह్ ธ ठ응

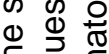

要

is $\overline{0}$

ฏ.

莡全向

ब $\frac{5}{9}$

ह ธ ठ

Ф

言齐告

可

旅尔

$0^{-3}$

ดั

ऊ范 。

$\stackrel{2}{\supset}$

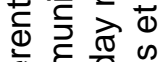

힌 융

흐을

ช $\overline{\overline{0}}$ 令

눙을 옹

के $\varepsilon$

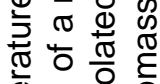

잉응 응

的

Q - 응

牙两的

त 00

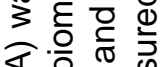

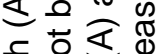

责施

कू

¿ 拜

응 항ㅎㅇ

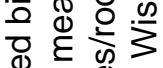

ஸิ)

至

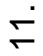

음 
variation in time and space (Grace and Wetzel 1978; Stanley et al. 1976); unfortunately, in these descriptions, no attention was paid to differences in latitude of the various sites within the lake nor to local differences in temperature or other environmental factors. It was mentioned, however, that flowering and the subsequent sloughing period were less predictable in southern locales than in northern ones.

Initial plant biomass values measured at a site in this lake studied in 1990 were very low, possibly because of grass carp herbivory the previous year, ${ }^{1}$ and initial rhizome/root crown mass has been set at the critical value of $12 \mathrm{~g} \mathrm{DW} \mathrm{m}^{-2}$. Rooting depth in the simulation was kept at $1.5 \mathrm{~m}$, although in reality water depth may have varied over $1.0 \pm 0.7 \mathrm{~m}$ within a year (Stanley et al. 1976).

Simulated biomass of the first plant cohort remained low. Only one apparent biomass peak could be distinguished, which originated from the second plant cohort. Simulated shoot biomass coincided in timing with measured shoot biomass, but the simulated peak was lower than the measured one (Figure 12). The latter difference may be a consequence of temporal decreases in water depth during the year; depth was kept constant in the simulation, leading to an underestimate of simulated plant biomass. Relatively small changes in water depth can cause large changes in net assimilation and biomass production (See Chapter 6).

To investigate which consequences a warm year for the milfoil community in this lake might have, when three instead of two plant cohorts are expected to be active, a model run was made with the same initial biomass and climatological data and a third cohort active (Figure 13). It turned out that in one year far higher shoot biomass values of approximately $950 \mathrm{~g} \mathrm{DW} \mathrm{m}^{-2}$ could be generated, similar in timing and value to maximum biomass values reported for the nearby Melton Hill Lake (Stanley et al. 1976), with rhizome/root crown biomass accumulating towards the end of the year. However, similar biomass values could also be reached earlier in the year when higher initial (nominal) biomass values were used as input, and only two cohorts active; in the latter case, biomass peaks of both plant cohorts appeared, and rhizome/root crown biomass was well above the critical level but not accumulating.

Simulation of a milfoil community in the Kashmir lakes, India, demonstrated that only one maximum in shoot biomass was generated (Figure 14), with a value somewhat higher than the measured range of 288 to $640 \mathrm{~g} \mathrm{DW} \mathrm{m}^{-2}$ and a rhizome/root crown biomass varying over a range close to the measured range of 32 to 160 (Zutschi and Vass 1973). The higher simulated shoot biomass may be due to the use of climatological data from Patancheru, which is located more south, and thus warmer, than the Kashmir lakes from which the measured biomass values originated (Patancheru $17^{\circ} \mathrm{N}$, Kashmir lake $32^{\circ} \mathrm{N}$ ); however, more northern climatological data from India were not available.

1 Personal Communication, M.S. Stewart, U.S. Army Engineer Waterways Experiment Station, Vicksburg, MS. 

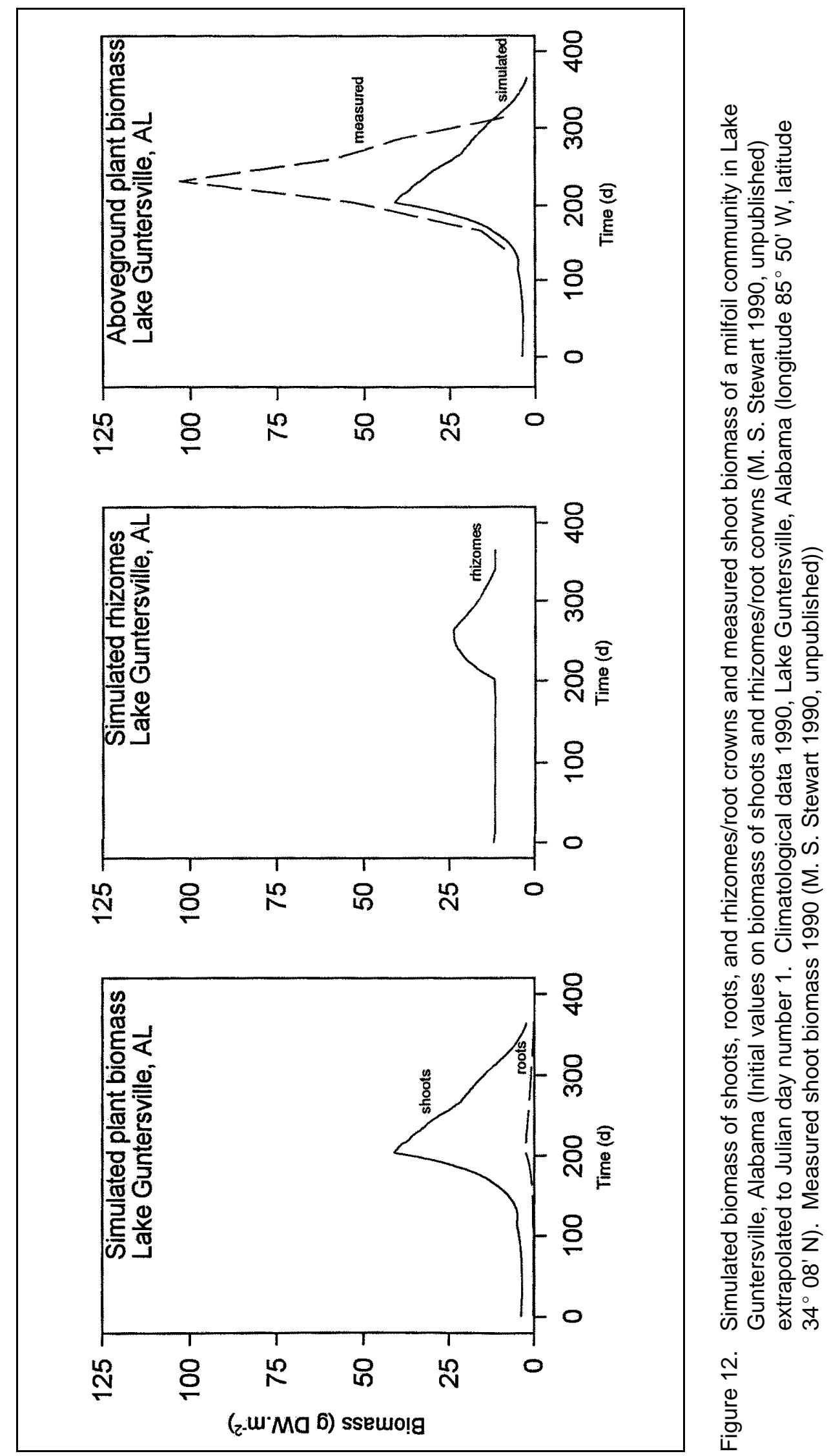

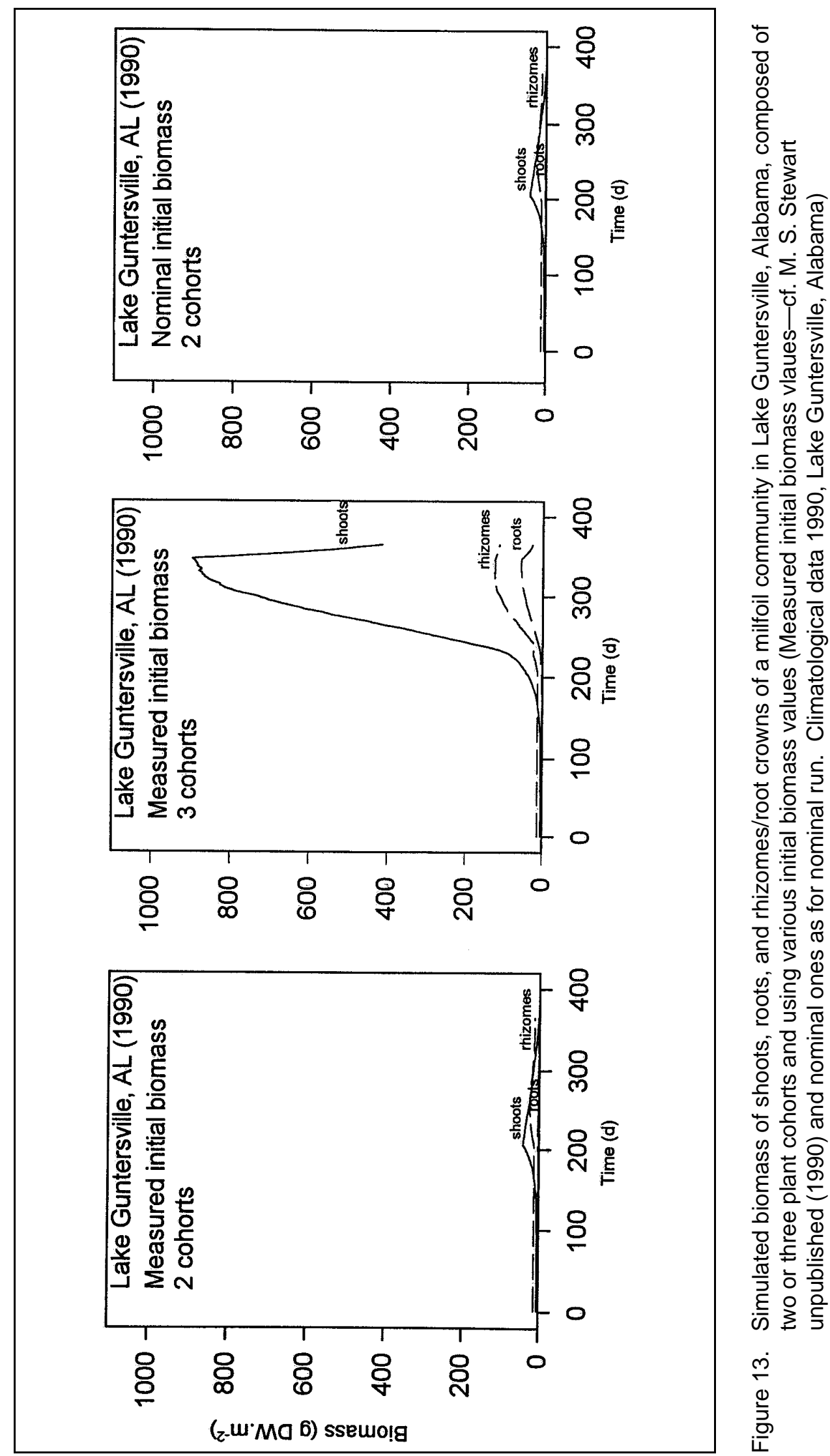

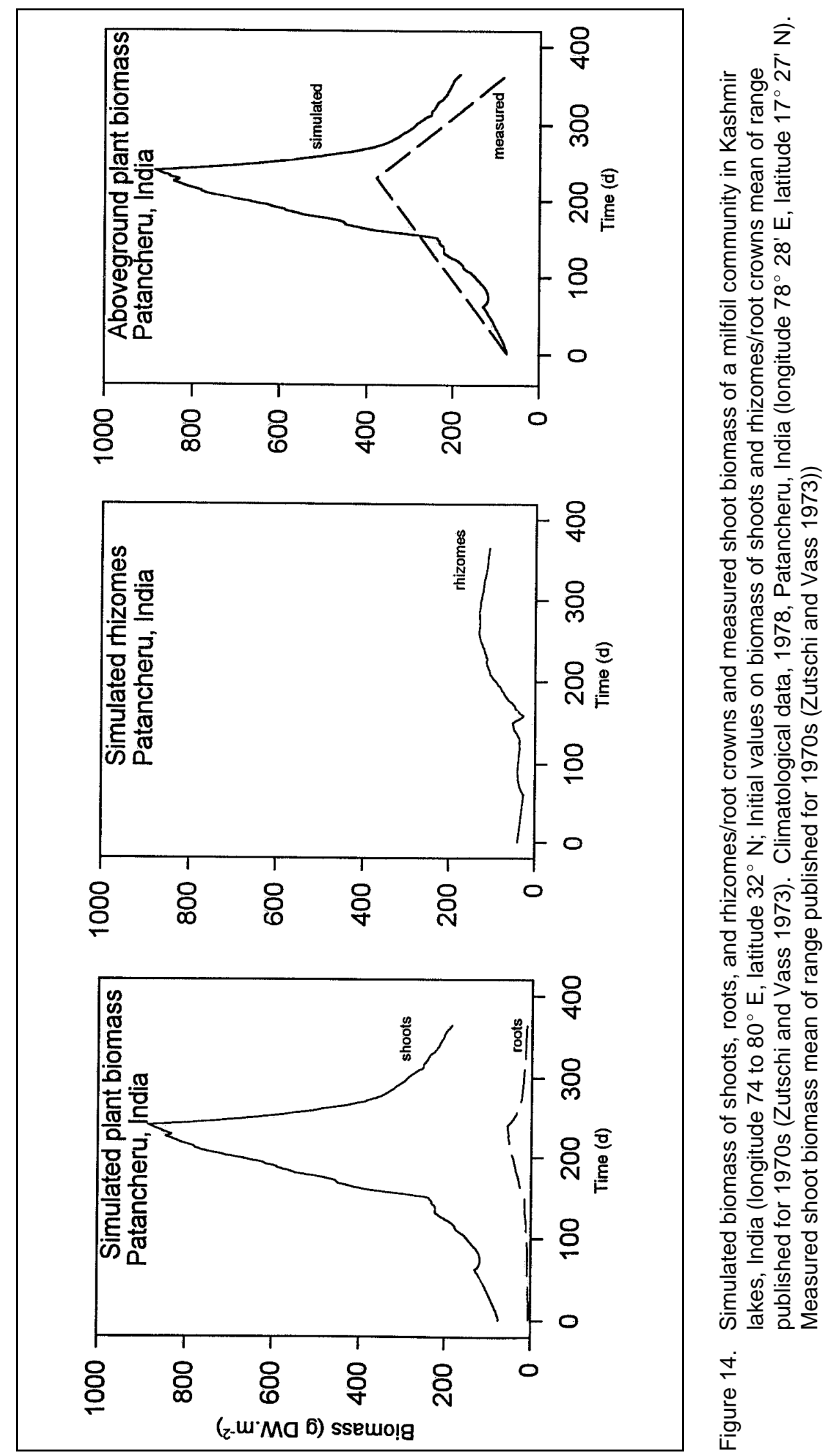

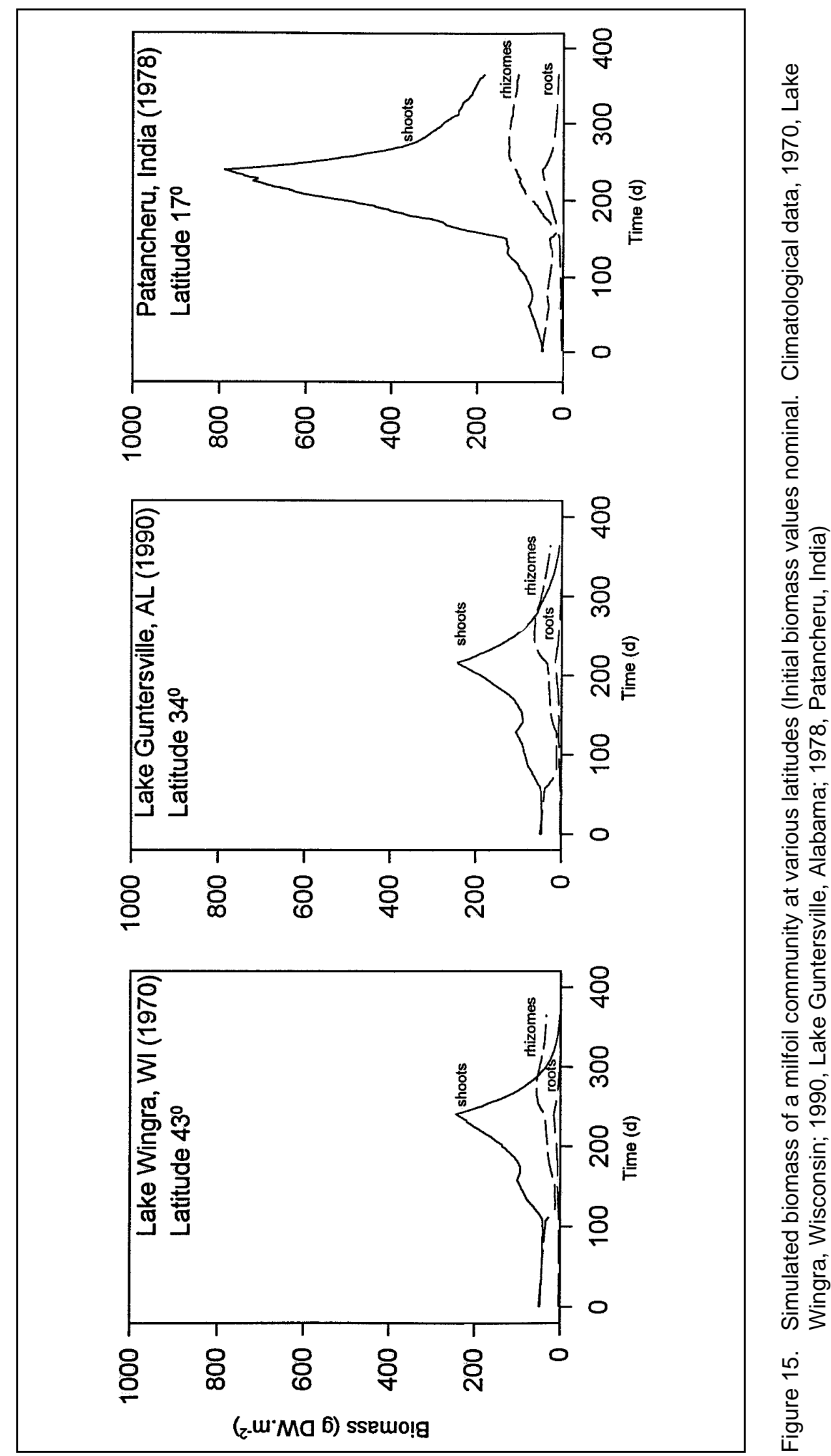
It was investigated whether milfoil benefits from adaptation to the tropics by producing thinner leaves. This was done because a higher leaf-surface area:dry weight ratio (K-value) has been found for milfoil in Japan $\left(0.01 \mathrm{~m}^{2} \mathrm{~g} \mathrm{DW}^{-1}\right.$; Ikusima 1970) than in Wisconsin $\left(0.006 \mathrm{~m}^{2} \mathrm{~g} \mathrm{DW}^{-1}\right.$; Titus and Adams 1979a). It turned out that timing was very similar and simulated plant biomass about 10 percent higher using the higher K-value (data not shown).

Running the model with nominal biomass values and climatological data typical for sites representative for temperate, temperate to tropical, and tropical climates (Figure 15) indicated that (a) in all climates one clear biomass peak is generated; (b) only in a temperate climate the biomass peak of both first and second cohorts can be distinguished; that is, from biomass values alone; flowering coinciding with every biomass maximum is always a suitable indicator, but it is often not noted in biomass studies; (c) peak biomass is expected to be highest in the tropics; that highest biomass values have been found at northern latitudes may be because most biomass studies on aquatic plants have been performed at the latter latitudes and biomass data from tropical areas are extremely scarce; and (d) end-of-year accumulation of rhizome/root crown biomass usually occurs in tropical, but not in temperate climates; that is, when three plant cohorts are active. 


\section{Sensitivity Analysis}

A sensitivity analysis of a simulation model is required to assess the parameters likely to strongly affect model behavior. The current analysis was based on the effect of a change in a parameter when all other parameters are kept the same. As reference level, the nominal parameter values were chosen as presented in Table 3, under Lake Wingra, Wisconsin, conditions at 1.5-m water depth. In a 1-year simulation starting with $50 \mathrm{~g} \mathrm{DW} \mathrm{m}^{-2}$ biomass for both plants and rhizome/root crown system, the value of the parameter under study was changed (Table 4). The results were compared with those of a nominal run. Each parameter was once increased by 20 percent and once decreased by 20 percent. The relative sensitivity (RS) of a parameter was then defined as the relative change in the variable on which the effect was tested divided by the relative change in the parameter ( $\mathrm{Ng}$ and Loomis 1984). The effects of 10 parameters on two variables, representing plant biomass aspects, were tested. A model variable is considered sensitive to a change in the value of a parameter at RS $>0.5$ and $<-0.5$. The current sensitivity analysis was performed over a 1 -year period.

$$
R S=\frac{\left(\text { yield }_{i}-\text { yield }_{r}\right) / \text { yield }_{r}}{\left(\text { param }_{i}-\text { param }_{r}\right) / \text { param }_{r}}
$$

where

yield $_{i}=$ value at parameter value $\mathrm{i}$

yield $_{r}=$ value at reference parameter value

$\operatorname{param}_{i}$ and $\operatorname{param}_{r}$ as above

Maximum plant biomass proved most sensitive to changes in potential $\mathrm{CO}_{2}$ assimilation at light saturation for shoot tips and very sensitive to changes in light-use efficiency. This is not surprising because the model is based on carbon flow through the plant. Changes in plant density did affect maximum plant biomass, but far less than photosynthetic activity at light saturation and light-use efficiency. Most parameter changes, except in critical rhizome weight, influencing rhizome/root crown biomass affected maximum plant biomass 
substantially, for example, initial rhizome weight, conversion rate into plant material, and translocation rate. In general, the same parameters as those for maximum plant biomass were important determinants of end-of-year rhizome/root crown biomass, with potential $\mathrm{CO}_{2}$ assimilation at light saturation, light-use efficiency, and relative death rate exhibiting the largest effects. This illustrates the utmost importance of the rhizome/root crown system for local survival and biomass production of milfoil.

Earlier or later flowering biotypes are suited to different environments. The effect of flowering date can be tested with the model by varying the development rate of the vegetation. Slower rates represent later and faster, earlier biotypes. Development rate slower or faster than the nominal rate leads to lower biomass. Faster development leads to a shorter growing season and less vegetative dry matter, incomplete light interception, and lower carbohydrate availability for organ formation. At the same time, however, the rate of organ formation increases, but the duration of each organ formation shortens. Intuitive prediction of biotype behavior under such highly variable climatic conditions is therefore hazardous. The model shows some promise in being able to reproduce some of these complex responses of the vegetation and may be useful in evaluating longterm implications of differences in development rate.

Although as far as is known, no publications exist on what the temperature requirements of aquatic plants are to traverse development from anthesis to senesced state; differences in postanthesis development rates for several wheat and rice cultivars are known to be small and have little effect on yield (Van Keulen 1976).

Maximum plant biomass proved only sensitive to a decrease in preanthesis development rate, while end-of-year rhizome/root crown biomass was sensitive to any change in preanthesis or postanthesis development rate. 


\begin{tabular}{|c|c|c|c|}
\hline $\begin{array}{l}\text { Table } 4 \\
\text { Relative Sensitivity of Two Model } \\
\text { Their Nominal Values (As present } \\
\text { simulation under Lake Wingra, W } \\
\text { rhizome biomass being } 50 \mathrm{~g} \mathrm{DW} \\
\end{array}$ & $\begin{array}{l}\text { Variables to } \\
\text { ed in Table 3) } \\
\text { isconsin, } 1970 \\
\left.n^{-2}\right)\end{array}$ & $\begin{array}{l}\text { eviations in Para } \\
\text { (Results were ob } \\
\text { conditions, star }\end{array}$ & $\begin{array}{l}\text { Values from } \\
\text { in a 1-year } \\
\text { th both plant and }\end{array}$ \\
\hline & & Rel & sitivity \\
\hline Parameter Name & Parameter Value & $\begin{array}{l}\text { Maximum Live Plant } \\
\text { Biomass }\end{array}$ & \begin{tabular}{|l|} 
End-of-Year \\
Rhizome/Root Crown \\
Biomass \\
\end{tabular} \\
\hline $\begin{array}{l}\text { Potential } \mathrm{CO}_{2} \text { assimilation rate at light saturation } \\
\text { for shoot tips }\end{array}$ & 0.0165 & & \\
\hline & 0.0200 & 1.96 & 2.00 \\
\hline & 0.0149 & 1.97 & 2.02 \\
\hline Light-use efficiency & 0.000011 & & \\
\hline & 0.000013 & 1.10 & 1.14 \\
\hline & 0.000008 & 1.22 & 1.25 \\
\hline Relative death rate leaves, stems, and roots & 0.042 & & \\
\hline & 0.050 & -0.62 & -1.01 \\
\hline & 0.034 & -0.77 & -1.36 \\
\hline Initial rhizome weight & 50 & & \\
\hline & 60 & 0.20 & 0.17 \\
\hline & 40 & 0.22 & 0.18 \\
\hline Critical rhizome weight & 12 & & \\
\hline & 14.4 & 0 & 0.05 \\
\hline & 9.6 & 0 & 0.06 \\
\hline Relative conversion rate of rhizomes into plant & 0.0576 & & \\
\hline & 0.069 & 0.19 & 0.17 \\
\hline & 0.046 & 0.21 & 0.18 \\
\hline Translocation rate & 0.35 & & \\
\hline & 0.42 & -0.13 & 0.57 \\
\hline & 0.28 & -0.14 & 0.72 \\
\hline Plant density & 11 & & \\
\hline & 13 & 0.16 & -0.79 \\
\hline & 9 & -0.16 & 0.79 \\
\hline Preanthesis development rate & 0.015 & & \\
\hline & 0.018 & -0.23 & -0.81 \\
\hline & 0.012 & -0.26 & -0.99 \\
\hline Postanthesis development rate & 0.015 & & \\
\hline & 0.018 & -0.69 & -0.89 \\
\hline & 0.012 & -0.79 & 0.66 \\
\hline
\end{tabular}




\section{Environmental Factor Analysis}

The impacts of various changes in environmental factors were assessed using the relative sensitivity of the affected variables as "measure." For this purpose, parameter changes were based on value ranges taken from literature, which sometimes differed more than 20 percent from the nominal parameter value given in Table 3.

\section{Climate}

Climate greatly affects plant-species distribution, phenological cycle, and biomass production. MILFO can be used to calculate climate change effects on the chronological timing of the phenological events and on biomass production. It cannot be used to assess climate change effects on (a) plant-species distribution and (b) the phenological cycle itself since the phenological cycle has been used for calibration (see Chapter 3). Running the model under more southern climatological conditions, i.e., changing the latitude from 43 to $34^{\circ} \mathrm{N}$ demonstrated that end-of-year rhizome/root crown biomass is far more sensitive to this climate change than maximum plant biomass (Table 5).

\section{Light-Reflection Coefficient at Water Surface}

The irradiance reflected at the water surface usually averages about 6 percent daily. The values of this parameter tested were 0 and 1 . Reflection may theoretically have the value 0 when no reflection occurs at a $90^{\circ}$ incoming angle of the radiation on a completely calm water surface (wind and wave action are minimal). The highest value of 1 may occur at a close to $180^{\circ}$ incoming angle of the radiation and at very rough water surfaces.

Increasing the light reflection coefficient to 1 annihilated plant biomass within the year. That nevertheless low RS values were found (Table 5) is an artifact of the calculation method employed. Decreasing the light-reflection 


\begin{tabular}{|c|c|c|c|}
\hline \multicolumn{4}{|c|}{ 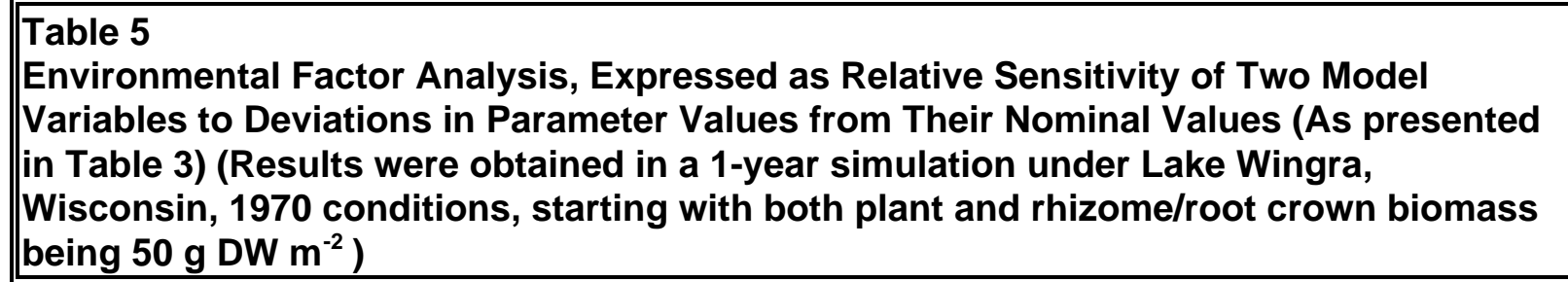 } \\
\hline \multirow[b]{2}{*}{ Parameter Name } & \multirow[b]{2}{*}{ Parameter Value } & \multicolumn{2}{|c|}{ Relative Sensitivity } \\
\hline & & \begin{tabular}{|l} 
Maximum Live Plant \\
Biomass
\end{tabular} & $\begin{array}{l}\text { End-of-Year Rhizome/Root } \\
\text { Crown Biomass }\end{array}$ \\
\hline \multicolumn{4}{|l|}{ Climate } \\
\hline Lake Wingra (1980) & Latitude $43^{\circ} \mathrm{N}$ & - & - \\
\hline Lake Guntersville (1990) & Latitude $34^{\circ} \mathrm{N}$ & -0.01 & 0.89 \\
\hline \multirow[t]{3}{*}{ Light-reflection coefficient at water surface } & 0.06 & & \\
\hline & $1.00(+1567 \%)$ & -0.05 & -0.04 \\
\hline & $0.00^{*}(-100 \%)$ & $\mid-0.07$ & $\mid-0.07$ \\
\hline \multirow[t]{3}{*}{ Light-extinction coefficient water column } & 1.80 & & \\
\hline & $2.16(+20 \%)$ & -0.92 & -1.01 \\
\hline & $1.44(-20 \%)$ & -1.12 & -1.01 \\
\hline \multirow[t]{3}{*}{ Water depth } & 1.5 & & \\
\hline & $1.8(+20 \%)$ & -0.31 & -0.31 \\
\hline & $1.2(-20 \%)$ & -0.34 & -0.33 \\
\hline
\end{tabular}

coefficient greatly increased maximum biomass and end-of-year rhizome/root crown biomass (Table 5).

\section{Light-Extinction Coefficient of Water Column}

A light-extinction coefficient of on average $1.80 \mathrm{~m}^{-1}$ is used for nominal runs of the model (Lake Wingra, Wisconsin).

Changing the light-extinction coefficient of the water column demonstrated large effects on maximum plant and end-of-year rhizome/root crown biomass. The often relatively small effect of an increase in light-extinction coefficient relative to the nominal value may be due to (a) the high nominal value and (b) the spatial distribution of milfoil plant biomass with typically 61 percent in the upper $0.5-\mathrm{m}$ water layer. A nominal value of $2 \mathrm{~m}^{-1}$ has been found typical for eutrophic fen lakes where submersed vegetation can just persist (Best, De Vries, and Reins 1985). The large effect of a decrease in light-extinction coefficient can largely be explained by greatly increased growth of the first plant cohort, 
boosting the rhizome/root crown system by translocation, thus providing a better start for the subsequent plant cohort(s) and resulting in a higher peak biomass.

\section{Water Depth}

MILFO has been calibrated for a water depth of $1.5 \mathrm{~m}$, the rooting depth of an extensively studied milfoil community in Lake Wingra, Wisconsin. The model has the capability to respond to fluctuations in water level with year, by (re)distributing plant biomass over the desired water depth (number of water layers; see Chapter 3). This technique for biomass distribution over the vertical axis of the community works well and gives realistic outcomes over a depth range of 0.5 to $6 \mathrm{~m}$.

Running MILFO at an increased or decreased water depth showed similar, relatively small effects on maximum plant and end-of-year rhizome/root crown biomass (Table 5).

The RS of peak plant biomass and end-of-year rhizome/root crown biomass to changes in water depth was relatively small and far lower than to changes in the light-extinction coefficient.

The current sensitivity and environmental analyses give indications of the sensitivity of maximum plant biomass and end-of-year rhizome/root crown systems for variations in plant parameters and environment over a 1-year period. It is to be expected, however, that the small changes that occurred over this relatively short period will increase with time and that these extrapolations in time will yield information on the likelihood for plant populations to ultimately persist or become extinct. Particularly, increases in water turbidity because of increased phytoplankton or periphyton growth stimulated by eutrophication, increased erosion/resuspension, and seasonal herbivory have been mentioned as decisive for the persistence of submersed plant populations. 


\section{Application Possibilities}

MILFO can be used to assess behavior of a milfoil community under various site-specific and climatological conditions as demonstrated in Chapters 4, 5, and 6 , and it can be run with user-specified input values for plant and rhizome/root crown biomass.

Effects of man-made control activities like harvesting at different times and at various water depths can be calculated also (Table 6). Thus, in the latter case it can be used as a tool for aquatic plant management agencies. From this table it can be concluded that harvesting at the end of May to a water depth of $0.8 \mathrm{~m}$ requires removal of a relatively low amount of biomass, but yields the lowest peak biomass and end-of-year rhizome/root crown biomass. This situation can be seen as favorable to control milfoil. In contrast, harvesting later in the year requires removal of relatively more plant biomass or allows for a relatively higher end-of-year rhizome/root crown biomass. Removing only the top layer of the plant community later in the year may even lead to increased maximum plant and end-of-year rhizome/root crown biomass, probably because of a temporarily higher light penetration within the community.

\begin{tabular}{|c|c|c|c|c|c|c|}
\hline \multicolumn{7}{|c|}{$\begin{array}{l}\text { Table } 6 \\
\text { Effects of Mechanical Harvesting Date and Depth on Plant and Rhizome/Root Crown } \\
\text { Biomass (Results were obtained in a 1-year simulation under Lake Wingra, Wisconsin, } \\
1970 \text { conditions, starting with both plant and rhizome/root crown biomass being } 50 \mathrm{~g} \\
\text { DW } \mathrm{m}^{-2} \text { ) }\end{array}$} \\
\hline Harvest Time & $\begin{array}{l}\text { Harvest } \\
\text { Depth } \\
\mathrm{m}\end{array}$ & $\begin{array}{l}\text { Live Plant } \\
\text { Biomass } \\
28 \text { August } \\
\text { g DW m-2 }\end{array}$ & $\begin{array}{l}\text { Preharvest } \\
\text { Biomass } \\
\text { g DW m }{ }^{-2}\end{array}$ & \begin{tabular}{|l} 
Postharvest \\
Biomass \\
g DW m-2
\end{tabular} & \begin{tabular}{|l} 
Day with \\
Zero Plant \\
Biomass
\end{tabular} & $\begin{array}{l}\text { End-of-Year Rhizome/ } \\
\text { Root Crown Biomass } \\
\text { g DW } \text { m}^{-2}\end{array}$ \\
\hline End of May & 0.8 & 84 & 100 & 21 & $>365$ & 13 \\
\hline End of June & 0.8 & 143 & 106 & 5 & $>365$ & 18 \\
\hline End of July & 0.8 & 49 & 171 & 8 & $>365$ & 14 \\
\hline End of July & 0.1 & 300 & 171 & 141 & $>365$ & 41 \\
\hline End of August & 0.8 & 258 & 244 & 11 & $>365$ & 18 \\
\hline End of September & 0.8 & 258 & 100 & 4 & $>365$ & 30 \\
\hline End of October & 0.8 & 258 & 33 & 1 & $>365$ & 33 \\
\hline
\end{tabular}


The current version of MILFO has been developed as a stand-alone simulation model. It can be relatively easily modified to communicate with ecosystem models because it is written in FORTRAN77 and its structure is simple. It is planned to link MILFO to a Geographical Information System through an appropriate interface like AEGIS+ (Luyten et al. 1994). To facilitate use of the current model, a user manual has been prepared (Best and Boyd, in preparation). 


\section{Discussion}

The current model gives a reasonable description of the dynamics in plant and rhizome/root crown biomass of an established milfoil population under a variety of field conditions. As can be expected, the model is very sensitive to environmental changes affecting the light climate and, consequently, the carbon flow through the plant.

Extinction of light by periphyton has not been included in MILFO because (a) the plant canopy tends to be at the water surface during most of the growth season, (b) irradiance in the euphotic zone of the plant canopy (upper layers) is often saturating (i.e., $>600 \mathrm{uE} \mathrm{cm}^{-2} \mathrm{~s}^{-1}$; Van, Haller, and Bowes 1976), and (c) no field data on periphyton biomass concomitant with photosynthetic activity are available at this time. Light attenuation by periphyton is expected to have large effects on submersed macrophyte species with most of their biomass concentrated just above the hydro-soil (like Ceratophyllum demersum; Best and Dassen 1987; Best and Jacobs 1990) and macrophytes with biomass that usually remains below the water surface (like Vallisneria americana; Titus and Adams 1979a).

Senescence, resulting in decreasing photosynthetic activity in aging plant parts, has been included into the model formulation. Although data quantifying these effects in milfoil were available (Adams and McCracken 1974; Adams, Titus, and McCracken 1974), running the model demonstrated that virtually no effect on peak biomass was noticeable, probably largely because of the typical umbrella-type biomass distribution over the water column, with not only most biomass in the upper portion of the community but also most young plant parts. 


\section{References}

Adams, M. S., and McCracken, M. D. (1974). "Seasonal production of the Myriophyllum component of the littoral of Lake Wingra, Wisconsin," Journal of Ecology 62, 457-466.

Adams, M. S., Titus, J. E., and McCracken, M. D. (1974), "Depth distribution of photosynthetic activity in a Myriophyllum spicatum community in Lake Wingra," Limnology and Oceanography 19, 377-389.

Aiken, S. G., Newroth, P., and Wile, I. (1979). "The biology of Canadian weeds (34), Myriophyllum spicatum L.," Canadian Journal of Plant Science 59, 201-215.

Allen, G. E. (1973). "Investigations and current status of insect enemies as biological control agents of aquatic weeds." Aquatic weeds in S.E. Asia. Proceedings of a regional seminar on noxious aquatic vegetation, New Delhi, 12-17 December, 1973. 299-306.

Amthor, J. S. (1984). "The role of maintenance respiration in plant growth," Plant, Cell, and Environment 7, 561-569.

Bayley, S., Stotts, V. D., Springer, P. F., and Steenis, J. (1978). "Changes in the submerged aquatic macrophyte populations at the head of the Chesapeake Bay 1958-1975," Estuaries 1, 73-84.

Best, E. P. H. (1981). "A preliminary model for growth of Ceratophyllum demersum L.," Verhaendlungen des Internationales Vereinigung fuer Limnologie 21, 1484-1491.

Best, E. P. H., and Boyd, W. A. (1996). "A simulation model for growth of the submersed aquatic macrophyte hydrilla (Hydrilla verticillata (L.F.) Royle," Technical Report A-96-8, U.S. Army Engineer Waterways Experiment Station, Vicksburg, MS. 
Best, E. P. H., and Boyd, W. A. "MILFO (Version 1.0): A simulation model for growth of Eurasian watermilfoil," Instruction Report in preparation, Environmental Laboratory, U.S. Army Engineer Research and Development Center, Vicksburg, MS.

Best, E. P. H., and Dassen, J. H. A. (1987). "Biomass, stand area, primary production characteristics and oxygen regime of the Ceratophyllum demersum L. population in Lake Vechten, The Netherlands," Archiv fuer Hydrobiologie/Supplement 76, 347-367.

Best, E. P. H., De Vries, D., and Reins, A. (1985). "The macrophytes in the Loosdrecht Lakes: A story of their decline in the course of eutrophication," Verhaendlungen des Internationalen Vereinigungs Theoretische und Angewandte Limnologie 22, 868-875.

Best, E. P. H., and Jacobs, F. H. H. (1990). "Potential and actual production of submerged aquatic angiosperms common in temperate regions." Proceedings, 8th Symposium on Aquatic Weeds. 39-47.

Bowes, G., Holaday, A. C., Haller, W. T. (1979). "Seasonal variation in the biomass, tuber density and photosynthetic metabolism in three Florida lakes," Journal of Aquatic Plant Management 17, 61-65.

Boyd, W. A., and Best, E. P. H. (1996). "HYDRIL (Version 1.0): A simulation model for growth of Hydrilla," Instruction Report A-96-1, U.S. Army Engineer Waterways Experiment Station, Vicksburg, MS.

Budd, J., Lillie, R. A., and Rasmussen, P. (1995). "Morphological characteristics of the aquatic macrophyte, Myriophyllym spicatum L., in Fish Lake, Wisconsin," Journal of Freshwater Ecology 10, 19-31.

Carpenter, S. R. (1980). "The decline of Myriophyllum spicatum in a eutrophic Wisconsin U.S.A. lake," Canadian Journal of Botany 58, 527-535.

Collins, C. D., and Wlosinski, J. H. (1985). "A macrophyte submodel for aquatic ecosystems," Aquatic Botany 33, 191-206.

Couch, R., and Nelson, E. (1985). "Myriophyllum spicatum in North America." Proceedings, First International Symposium on Watermilfoil (Myriophyllum spicatum) and Related Haloragaceae Species, 23-24 July 1985, Vancouver, BC. 8-18.

Engel, S. (1993). "Status of Eurasian watermilfoil in Wisconsin," LakeLine 13, 10-13.

Gijzen, H. (1985). “Simulatie van drogestof-produktie en de Leaf Area Index van cassave," M.S. thesis, Department of Tropical Crop Science, Wageningen Agricultural University, The Netherlands (In Dutch). 
Golterman, H. L. (1975). Physiological limnology. An approach to the physiology of lake ecosystems." Elsevier Scientific Publishing Company, Amsterdam.

Goudriaan, J. (1986). "A simple and fast numerical method for the computation of daily totals of crop photosynthesis," Agricultural and Forest Meteorology $38,251-255$.

Goudriaan, J., Van Keulen, H., and Van Laar, H. H. (1992). "Crop growth model for potential production (SUCROS1)." Simulation of crop growth for potential and water-limited production situations (as applied to spring wheat). Post-graduate course "Simulation of plant growth and crop production." Pontignano, Siena, Italy, 3-12 November, 1992, 1-25.

Grace, J. B., and Wetzel, R. G. (1978). "The production biology of Eurasian watermilfoil (Myriophllym spicatum L.): A review," Journal of Aquatic Plant Management 16, 1-11.

Grainger, J. (1947). "Nutrition and flowering of water plants," Journal of Ecology 35, 49-64.

Griffin, K. L. (1994). "Caloric estimates of construction cost and their use in ecological studies," Functional Ecology 8, 551-562.

Guppy, H. B. (1897). "On the postponement of germination of seeds of aquatic plants," Proceedings of the Royal Physiological Society of Edinburgh 13, 344-360.

Hartleb, C. F., Madsen, J. D., and Boylen, C. W. (1993). "Environmental factors affecting seed germination in Myriophyllum spicatum L.," Aquatic Botany 45, 15-25.

Hootsmans, M. J. M. (1991). "A growth analysis model for Potamogeton pectinatus L.," M. J. M. Hootsmans and J. E. Vermaat. Macrophytes, a key to understanding changes caused by eutrophication in shallow freshwater ecosystems. IHE Report Series 21, Delft, The Netherlands, 263-311.

Hootsmans, M. J. M. (1994). “A growth analysis model for Potamogeton pectinatus L.," W. Van Vierssen, M. Hootsmans, and J. Vermaat. Lake Veluwe, a macrophyte-dominated system under eutrophication stress. Geobotany 21 , Kluwer Academic Publishers, Dordrecht/Boston/London, 250-286.

Hunt, R. (1982). "Plant growth curves.” Arnold, London.

Hutchinson, G. E. (1975). "A treatise on limnology. Volume 3. Limnological botany." J. Wiley \& Sons, New York. 
Ikusima, I. (1970). "Ecological studies on the productivity of aquatic plant communities. IV. Light condition and community photosynthetic production," Botanical Magazine of Tokyo 83, 330-340.

Jeschke, L., and Muther, K. (1978). "Plant sociology of the Rheinsberger lakes," Limnologica 11, 307-353.

Jupp, B. P., and Spence, D. H. N. (1977). "Limitations of macrophytes in a eutrophic lake, Loch Leven. II. Wave action, sediments and waterfowl grazing," Journal of Ecology 65, 431-446.

Kooman, P. L. (1995). "Genotype-environment interaction in potato 2: Dry matter allocation and duration of the growth cycle." Yielding ability of potato crops as influenced by temperature and daylength. Thesis Agricultural University Wageningen, Chapter 5, 71-89.

Lee, G. F., and Kluesener, J. W. (1972). "Nutrient transport and transformation in Lake Wingra, Wisconsin," Eastern Deciduous Forest Biome MemoReport 72-42.

Lind, C. T., and Cottam, G. (1969). "The submerged aquatics of University Bay: A study in eutrophication," American Midland Naturalist 81, 353-369.

Lundegardh-Ericson, C. (1972). "Changes during four years in the macrovegetation in a flad in Northern Stockholm Archipelago," Svensk Botanische Tidskrift 66, 207-225.

Luyten, J. C., Jones, J. W., Calixte, J. P., Hoogenboom, G., and Negahban, B. (1994). "AEGIS+. Agricultural and Environmental Geographic Information System plus. Version 2.0," User's and Developer's Manual, Research Report AGE No.94-1, Agricultural Engineering Department, Institute of Food and Agricultural Sciences, University of Florida, Gainesville, FL.

Madsen, J. D. (1997). "Seasonal biomass and carbohydrate allocation in a southern population of Eurasian watermilfoil," Journal of Aquatic Plant Management 35, 15-21.

Madsen, J. D., Eichler, L. W., and Boylen, C. W. (1988). "Vegetative spread of Eurasian watermilfoil in Lake George, New York," Journal of Aquatic Plant Management 26, 47-50.

Madsen, J. D., and Smith, D. H. (1997). "Vegetative spread of Eurasian watermilfoil colonies," J. Aquat. Plan Manage. 35, 63-68.

Ng, E., and Loomis, R. S. (1984). "Simulation of growth and yield of the potato crop," Simulation Monographs, Pudoc, Wageningen. 
Nichols, S. A. (1971). "The distribution and control of macrophyte biomass in Lake Wingra," Publication Water Resources Center, Hydraulic Sanitary Laboratory, University of Wisconsin.

(1984). "Macrophyte community dynamics in a dredged Wisconsin Lake," Water Resources Bulletin 20, 573-576.

Nichols, S. A., and Shaw, B. H. (1986). "Ecological life histories of the three aquatic nuisance plants, Myriophyllum spicatum, Potamogeton crispus and Elodea canadensis," Hydrobiologia 131, 3-21.

Oglesby, R. T., Vogel, A., Peverly, J. H., and Johnson, R. (1976). "Changes in submerged plants at the south end of Cayuga Lake following tropical storm Agnes," Hydrobiologia 48, 251-255.

Patten, B. C. (1954). "The status of some American species of Myriophyllum as revealed by the discovery of intergrade material between M.exalbescens Fern. and M.spicatum L. in New Jersey," Rhodora 56, 213-225.

. (1955). "Germination of the seed of Myriophyllum spicatum L.," Bulletin of the Torrey Botanical Club 82, 50-56.

. (1956). "Notes on the biology of Myriophyllum spicatum L. in a New Jersey lake," Bulletin of the Torrey Botanical Club 83, 6-17.

Penning de Vries, F. W. T. (1975). "The cost of maintenance processes in plant cells," Annals of Botany 39, 77-92.

Penning de Vries, F. W. T., Jansen, D. M., Ten Berge, H. F. M., and Bakema, A. (1989a). "Morphological development and assimilate partitioning,"

Simulation of ecophysiological processes of growth in several annual crops. Chapter 3, Pudoc, Wageningen, 49-56.

. (1989b). "Morphological development and assimilate partitioning," Simulation of ecophysiological processes of growth in several annual crops. Chapter 3, Pudoc, Wageningen, 73-115.

Penning de Vries, F. W. T., and Van Laar, H. H. (1982a). "Simulation of growth processes and the model BACROS." Simulation of plant growth and crop production. Pudoc, Wageningen, 99-102.

. (1982b). "Simulation of growth processes and the model

BACROS." Simulation of plant growth and crop production, Pudoc, Wageningen, 114-131.

Rabbinge, R., and De Wit, C. T. (1989). "Theory of modelling and systems management." Simulation and systems management in crop protection. Chapter 1. R. Rabbinge, S. A. Ward, and H. H. van Laar, ed., Simulation Monographs 32, Pudoc, Wageningen, 1-12. 
Reed, C. F. (1977). "History and distribution of Eurasian watermilfoil in United States and Canada," Phytologia 36, 416-436.

Scales, P., and Bryan, A. (1979). "Studies on aquatic macrophytes part 27. Transport of Myriophyllum spicatum fragments by boaters and assessment of the 1978 boat quarantine program," British Columbia Ministry of the Environment, Water Investigation Branch, Victoria.

Scheffer, M. (1991). "On the prediction of aquatic vegetation in shallow lakes," Memorie dell' Istituto Italiano di Idrobiologia 48, 207-217.

Scheffer, M., Bakema, A. H., and Wortelboer, F. G. (1993). "MEGAPLANT: A simulation model of the dynamics of submerged plants," Aquatic Botany $45,341-356$.

Smith, C. S., and Adams, M. S. (1986). "Phosphorus transfer from sediments by Myriophyllum spicatum," Limnology and Oceanography 31, 1312-1321.

Spencer, W., and Bowes, G. (1990). "Ecophysiology of the world's most troublesome aquatic weeds," Aquatic weeds. The ecology and management of nuisance aquatic vegetation. A. H. Pieterse and K. J. Murphy, ed., Oxford University Press, 39-74.

Spencer, D. F., Ryan, F. J., and Ksander, G. G. (1997). "Construction costs for some aquatic plants," Aquatic Botany 56, 203-214.

Spitters, C. J. T. (1986). "Separating the diffuse and direct component of global radiation and its implications for modeling canopy photosynthesis.

II. Calculation of canopy photosynthesis," Agricultural and Forest meteoro$\operatorname{logy} 38,231-242$.

Standifer, N. E., and Madsen, J. D. (1997). "The effect of drying period on the germination of Eurasian watermilfoil seeds," Journal of Aquatic Plant Management 35, 35-36.

Stanley, R. A., and Nailor, A. W. (1972). "Photosynthesis in Eurasian watermilfoil (Myriophyllum spicatum L.)," Plant Physiology 50, 149-151.

Stanley, R. A., Shackleford, E., Wade, D., and Warren, C. (1976). "Effects of season and water depth on Eurasian watermilfoil," Journal of Aquatic Plant Management 14, 32-36.

Thornley, J. H. M., and Johnson, I. R. (1990a). "Temperature effects on plant and crop processes." Plant and crop modelling. A mathematical approach to plant and crop physiology. Clarendon Press, Oxford, 139-144. . (1990b). "Plant growth functions." Plant and crop modelling. A mathematical approach to plant and crop physiology." Clarendon Press, Oxford, 74-89. 
Titus, J., and Adams, M. A. (1979a). "Coexistence and the comparative light relations of the submersed macrophytes Myriophyllym spicatum L. and Vallisneria americana Michx.," Oecologia 40, 273-286.

. (1979b). "Comparative storage utilization patterns in the submersed macrophytes, Myriophyllum spicatum and Vallisneria americana," The American Midland Naturalist 102, 263-272.

Titus, J. E., and Stone, W. H. (1982). "Photosynthetic response of two submersed macrophytes to dissolved inorganic carbon cancentration and $\mathrm{pH}$," Limnology and Oceanography 27, 151-160.

Titus, J., Goldstein, R. A., Adams, M. A., Mankin, J. B., O’Neill, R. V., Weiler, P. R., Shugart, H. H., and Booth, R. S. (1975). "A production model for Myriophyllum spicatum L.," Ecology 56, 1129-1138.

Van, T. K., Haller, W. T., and Bowes, G. (1976). "Comparison of the photosynthetic characteristics of three submersed aquatic plants," Plant Physiology $58,761-768$.

Van der Zweerde, W. (1981). "Research of the influence of light intensity and day length on the formation of turions in the aquatic macrophyte Hydrilla verticillata Royle," Student Report, Centre for Agrobiological Research, Wageningen (In Dutch).

Van Keulen, H. (1976). "Evaluation of models." Critical evaluation of systems analysis in ecosystems research and management. G. W. Arnold and C. T. de Wit, ed., Simulation Monographs, Pudoc, Wageningen, 22-29.

Van Kraalingen, D. W. G. (1995). "The FSE system for crop simulation," $A B$-DLO Report. Wageningen, The Netherlands.

Vogt, K. A., Vogt, D. J., and Bloomfield, J. (1991). "Input of organic matter to the soil by tree roots." Plant roots and their environment. B. L. MicMichael and H. Persson, ed., Elsevier Science Publications, 171-190.

Wetzel, R. L., and Neckles, H. A. (1996). “A model of Zostera marina L. photosynthesis and growth: Simulated effects of selected physical-chemical variables and biological interactions," Aquatic Botany 26, 307-323.

Williams, K., Percival, F., Merino, J., and Mooney, H. A. (1987). "Estimation of tissue construction cost from heat combustion and organic nitrogen content," Plant Cell and Environment 10, 725-734.

Zutschi, D. P., and Vass, K. K. (1973). "Ecology of macrophyte vegetation of Kashmir lakes," Aquatic weeds in S. E. Asia. Proceedings of a regional seminar on noxious aquatic vegetation, New Delhi, 12-17 December, 1973. 141-146. 


\section{Appendix A Model Listing}




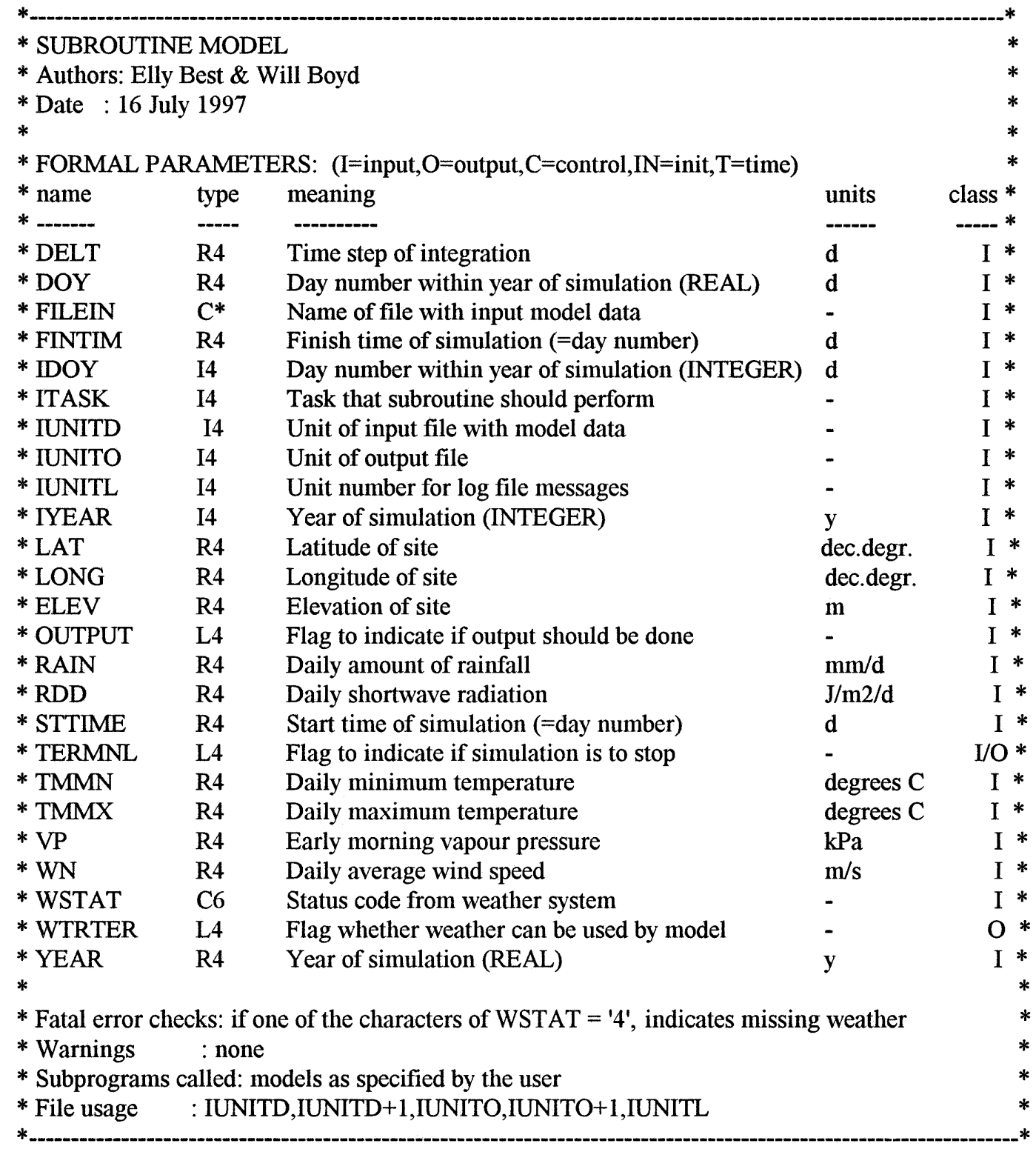

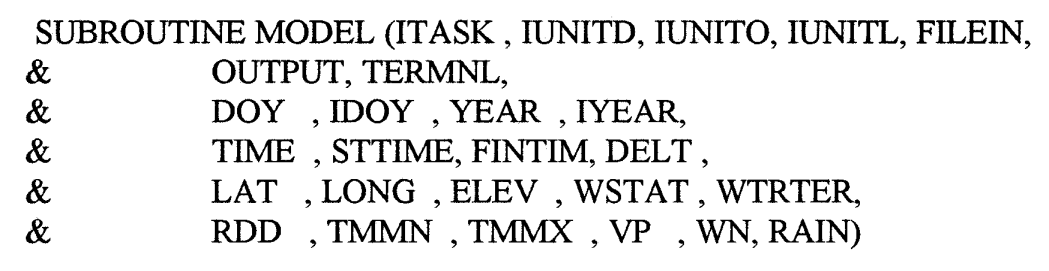

*-----Title of the program

* <Fill in your title here >

* MILFO

IMPLICIT REAL (A-Z)

*.----Formal parameters 
INTEGER ITASK, IUNITD, IUNITO, IUNITL, IDOY, IYEAR

LOGICAL OUTPUT, TERMNL, WTRTER

CHARACTER $\left.*{ }^{*}\right)$ FILEIN, WSTAT

REAL DOY, YEAR, TIME, STTIME, FINTIM, DELT

REAL LAT, RDD, TMMN, TMMX, VP, WN, RAIN

REAL TMAX(365), TMIN(365)

*-----Standard local declarations

INTEGER IWVAR,ITOLD,IDAY, DDELAY

CHARACTER WUSED*6

*-----State variables, initial values and rates

REAL DVS ,NUL ,DVR ,TMPSUM,TMP2

REAL TWLG1 ,TWSG1 ,TWRG1 ,IWLG1 ,IWSG1,IWRG1

REAL TWLD1 ,TWSD1, TWRD1 ,IWLD1 ,IWSD1,IWRD1

REAL TWLG2 ,TWSG2, TWRG2 ,IWLG2 ,IWSG2,IWRG2

REAL TWLD2 ,TWSD2, TWRD2 ,IWLD2, ,IWSD2,IWRD2

REAL TWLG3 ,TWSG3 ,TWRG3 ,IWLG3 ,IWSG3,IWRG3

REAL TWLD3 ,TWSD3 ,TWRD3 ,IWLD3 ,IWSD3,IWRD3

REAL NGLV1 ,NGST1 ,NGRT1 ,DLV1 ,DST1 ,DRT1

REAL NGLV2, NGST2, NGRT2, DLV2 ,DST2 ,DRT2

REAL NGLV3, NGST3 ,NGRT3,DLV3 ,DST3 ,DRT3

REAL TWLVG ,TWLVD ,TWSTG ,TWSTD ,TWRTG,TWRTD

REAL TWGRIZ,TWRIZD,IWGRIZ,IWRIZD,TGRIZ

*-----Model parameters

REAL AMX ,CVT ,DAYEM ,DELAY ,DEPTH ,EE

REAL HAR ,HARDAY,HARDEP

REAL NPL ,RC ,RCSHST,REDAM, RDRIZ

REAL ROC ,TBASE,TRAFAC,TL

*-----Auxiliary variables

REAL AMAX , AMTMP , ASRQ , COSLD , WTMP

REAL DAVTMP, DAY , DAYL , DDTMP , DSO

REAL DSINB , DSINBE, DTEFF , DTGA , FGROS

REAL FLV , FRT , FRT1 , FRT2 , FST

REAL GLV , GPHOT , GRT , GST , GTW

REAL MAINT , MAINTS, PI , RDR , RDS

REAL REMOB1, REMOB2, REMOB3, SC , SINLD

REAL SUM , TEFF , TGW , TGWM , TRANS1

REAL TRANS2, TRANS3, TREMOB, TW , WLV

REAL WST , WRT , MAINRT, YRNUM

*-----AFGEN functions

REAL AMTMPT

INTEGER IMAMTM, ILAMTM

PARAMETER (IMAMTM $=40$ )

DIMENSION AMTMPT(IMAMTM)

REAL FLT

INTEGER IMFLT, ILFLT

PARAMETER $($ IMFLT $=40$ )

DIMENSION FLT (IMFLT)

REAL FLVT 


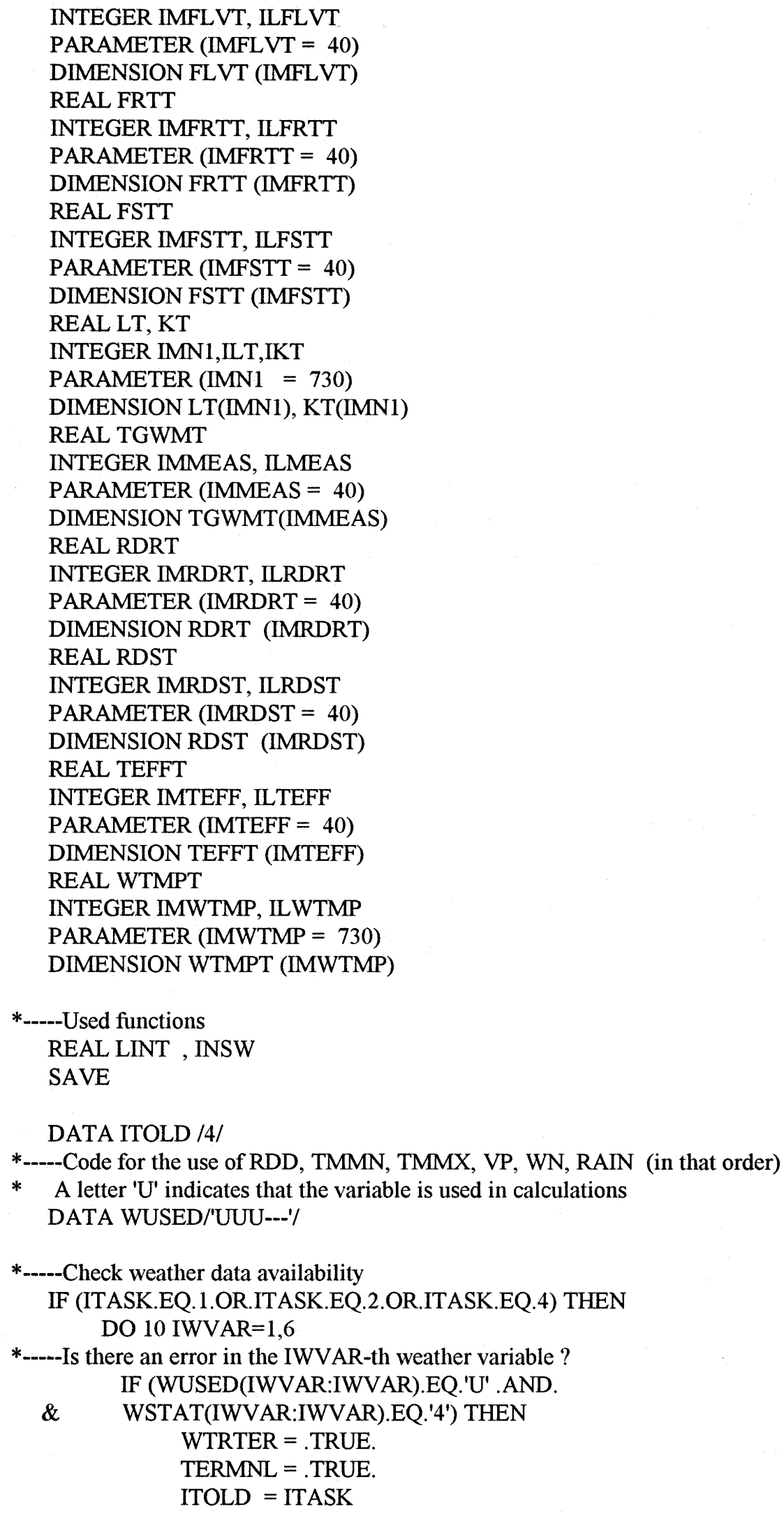




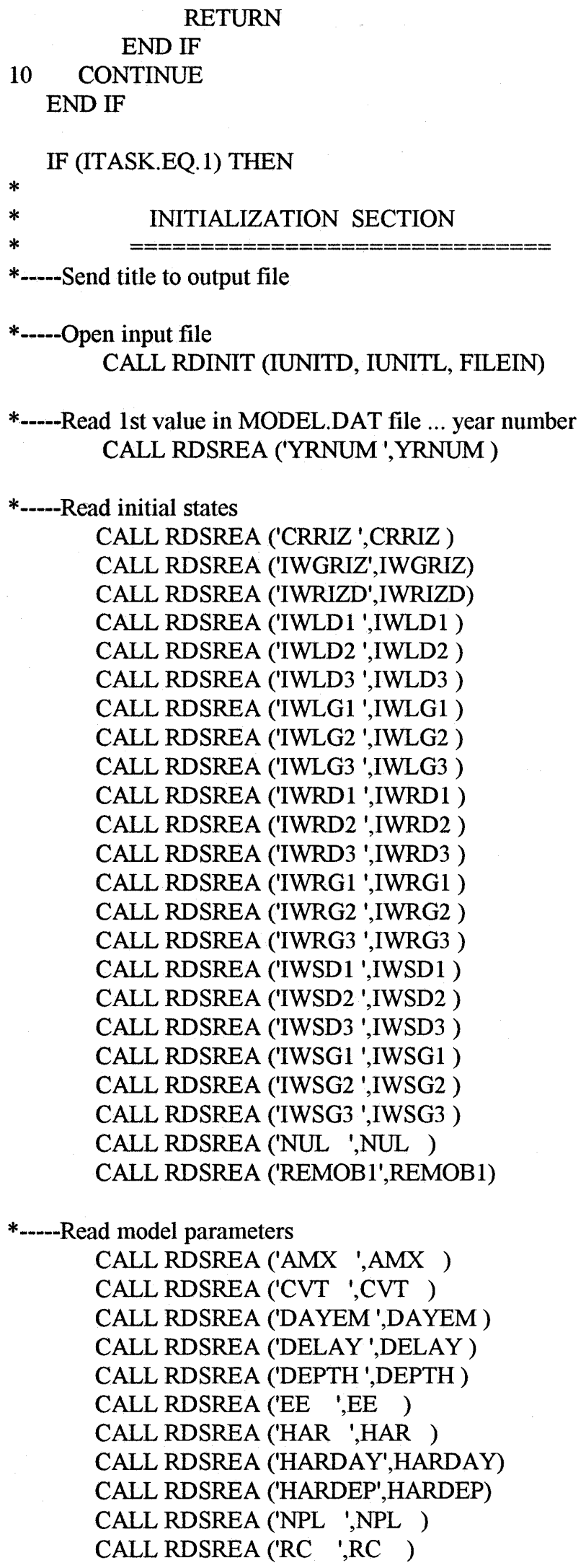


CALL RDSREA ('RCSHST',RCSHST)

CALL RDSREA ('REDAM ',REDAM)

CALL RDSREA ('RDRIZ ',RDRIZ)

CALL RDSREA ('ROC ',ROC )

CALL RDSREA ('TBASE ',TBASE )

CALL RDSREA ('TL ',TL )

CALL RDSREA ('TRAFAC', TRAFAC)

*-----Read AFGEN functions

CALL RDAREA ('AMTMPT',AMTMPT,IMAMTM,ILAMTM)

CALL RDAREA ('FLT ',FLT ,IMFLT, ILFLT)

CALL RDAREA ('FLVT ',FLVT ,IMFLVT,ILFLVT)

CALL RDAREA ('FSTT ',FSTT ,IMFSTT,ILFSTT)

CALL RDAREA ('FRTT ',FRTT ,IMFRTT,ILFRTT)

CALL RDAREA ('KT ',KT ,IMN1 ,IKT )

CALL RDAREA ('LT ',LT ,IMN1, ILT )

CALL RDAREA ('RDRT ',RDRT ,IMRDRT,ILRDRT)

CALL RDAREA ('RDST ',RDST ,IMRDST,ILRDST)

CALL RDAREA ('TEFFT ',TEFFT ,IMTEFF,ILTEFF)

CALL RDAREA ('TGWMT ',TGWMT ,IMMEAS,ILMEAS)

CALL RDAREA ('WTMPT ',WTMPT ,IMWTMP,ILWTMP)

*** INITIAL CALCULATIONS $\quad * * *$

* $=================$

*-----Initially known variables to output

* Send title(s) to OUTCOM

*-----Initialize state variables

* Start at the beginning of the developmental cycle

DVS $=$ NUL

TMPSUM $=$ NUL

*-----Delay variable set from a REAL to an INTEGER

DDELAY $=$ DELAY

*-----Initialize weights of plant organs

IF (YRNUM .EQ. 1.)THEN

TWLD1 $=$ IWLD1

TWLD2 $=$ IWLD2

TWLD3 = IWLD3

TWLG1 $=$ IWLG1

TWLG2 = IWLG2

TWLG3 = IWLG3

TWSD $1=$ IWSD 1

TWSD2 $=$ IWSD2

TWSD $3=$ IWSD 3

TWSG1 $=$ IWSG1

TWSG2 = IWSG2

TWSG3 $=$ IWSG3

TWRD1 $=$ IWRD 1

TWRD2 = IWRD2

TWRD3 $=$ IWRD3

TWRG1 = IWRG1 


$$
\begin{aligned}
& \text { TWRG2 }=\text { IWRG2 } \\
& \text { TWRG3 }=\text { IWRG3 } \\
& \text { TWGRIZ }=\text { IWGRIZ } \\
& \text { TWRIZD }=\text { IWRIZD } \\
& \text { ENDIF }
\end{aligned}
$$

ELSE IF (ITASK.EQ.2) THEN

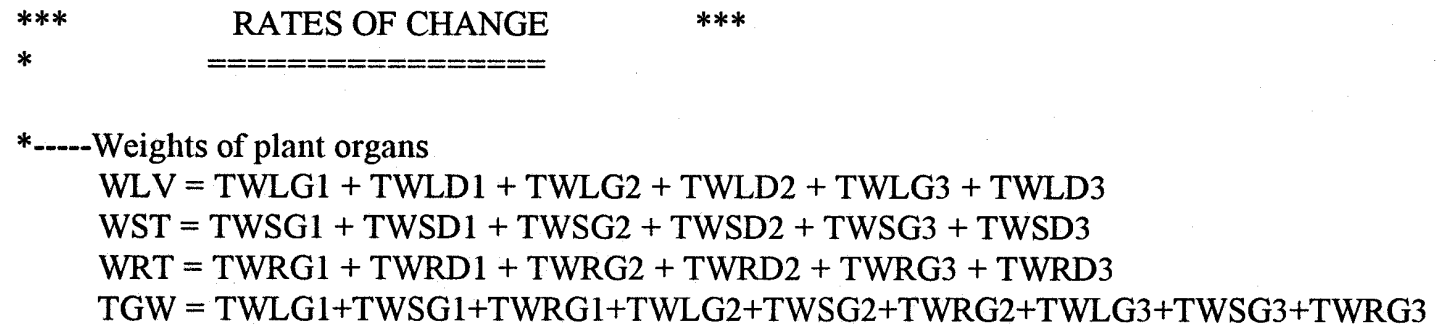

*-----If water temperatures are available, temperature dependent processes are related to water

* temperature; otherwise they are related to air temperature with a lag period in day(s) to be chosen

* by substituting number given for DELAY in MODEL.DAT

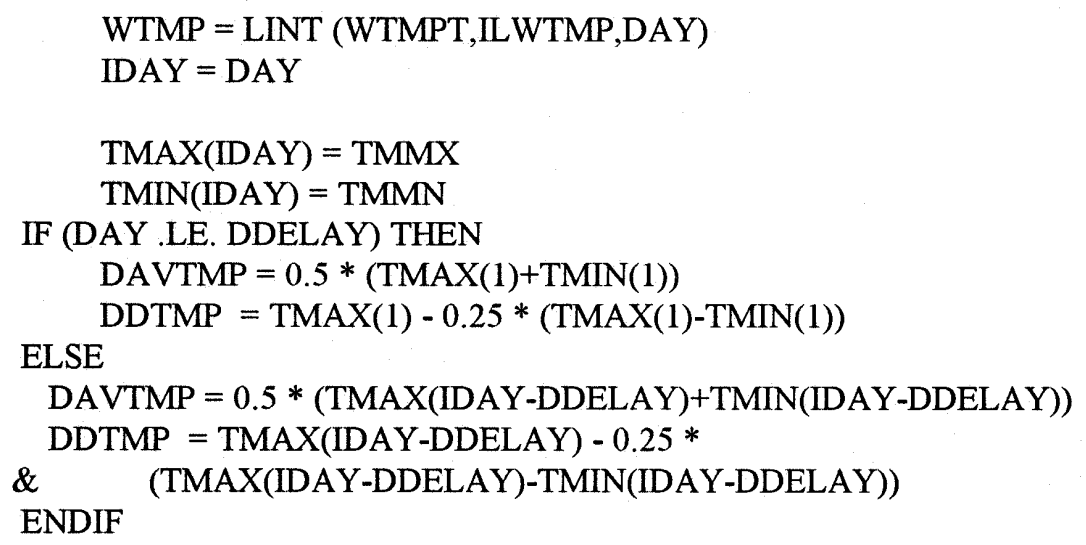


TEFF $=$ LINT(TEFFT,ILTEFF,DDTMP)

*-.---Measured total live plant dry weight TGWM = LINT (TGWMT,ILMEAS,DAY)

*----Call to SBRT ASTRO to introduce day length into MAIN for tentative

* relationship REMOB1-DAYL; otherwise this call can be made at *ASTRO

CALL ASTRO

\$ (DAY,LAT,SC,DS0,SINLD,COSLD,DAYL,DSINB,DSINBE)

*-----Calculation of dry matter and its partitioning over the plant organs

$\mathrm{TW}=\mathrm{TGW}+(\mathrm{TWLD} 1+\mathrm{TWSD} 1+\mathrm{TWRD} 1+\mathrm{TWLD} 2+\mathrm{TWSD} 2+\mathrm{TWRD} 2+\mathrm{TWLD} 3+\mathrm{TWSD} 3+\mathrm{TWRD} 3)$

FLV $=$ LINT(FLVT, ILFLVT,DVS)

FST $=$ LINT(FSTT, ILFSTT,DVS)

FRT $=$ LINT(FRTT, ILFRTT,DVS)

$\mathrm{FL}=$ LINT(FLT, ILFLT, $\mathrm{DVS})$

*-----Growth of plant organs, maintenance respiration and translocation

* Calculation assimilate requirement for plant organ formation.

ASRQ $=1.54$

MAINTS $=0.016 *$ TWLG1 $+0.01 *$ TWSG1 $+0.015 *$ TWRG1

MAINT $=$ MAINTS $*$ TEFF

MAINRT $=0.005 *$ TWGRIZ $*$ TEFF

*-----Carbohydrate behavior: remobilization from rhizomes for plant formation at proper day length and

* temperature conditions (presently related to DVS); translocation from above-ground biomass

* (i.e.'plants') to rhizomes, provided plants are present

TRANS $1=0.0$

TREMOB $=0.0$

TWGRIZ = AMAX1 (CRRIZ, TWGRIZ)

TGRIZ $=$ TWGRIZ

TWRIZD = INTGRL $($ TWRIZD, RDRIZ, DELT $)$

IF (DVS.GE.0.376 .AND. DVS.LT.1.0) THEN

IF (GPHOT .LT. MAINT)THEN

IF (TWGRIZ .GT. CRRIZ) THEN

TREMOB = INTGRL $($ TREMOB, REMOB 1, DELT $)$

REMOB1 $=$ ROC $*$ TWGRIZ

ELSE

WRITE $(*, *)$ 'Vegetation is dying'

REMOB $1=0.000001$

ENDIF

ENDIF

ELSE

REMOB $1=0.000001$

ENDIF

*-----Relative death rates

RDR = INSW (DVS-1.001,0.,LINT (RDRT,ILRDRT,DDTMP))

RDS $=$ INSW (DVS-1.001,0.,LINT (RDST,ILRDST,DDTMP)) 
*-----Development rates

IF(DAVTMP .LT. 3.0) THEN

$\mathrm{DVR}=0.0$

ELSE IF (DVS.LE. 1.) THEN

$\mathrm{DVR}=0.022 * \mathrm{DAVTMP} / 30$

ELSE IF (DVS.LE.6.0) THEN

$\mathrm{DVR}=0.015 * \mathrm{DAVTMP} / 30$

ENDIF

*-----Calculation of effective daytime temperature

DTEFF = AMAX1(0.,DAVTMP-TBASE)

*-----Calculation of dead plant material per organ

DLV1 $=$ TWLG1 $*$ RDR

DST1 $=$ TWSG1 $*$ RDR

$\mathrm{DRT} 1=\mathrm{TWRG} 1 * \mathrm{RDR}$

*-----Shoot photosynthesis at light saturation, and daytime temperature effect on shoot photosynthesis $\mathrm{AMAX}=\mathrm{AMAX} 1(0.00001, \mathrm{AMX} * \mathrm{AMTMP})$

AMAX $=$ AMAX $*$ REDAM

AMTMP $=$ LINT(AMTMPT,ILAMTM,DDTMP)

*-----Before calling TOTASS, determine light extinction coefficients of plant material $(\mathrm{K})$ and water $(\mathrm{L})$

$\mathrm{L}=\mathrm{LINT}(\mathrm{LT}, \mathrm{ILT}, \mathrm{TIME})$

$\mathrm{K}=\mathrm{LINT}(\mathrm{KT}, \mathrm{IKT}, \mathrm{DVS})$

*-----Daily total gross assimilation

CALL TOTASS

$\$$ (SC,DAYL,SINLD,COSLD,DSINBE,RDD,RC,L,K,AMAX,EE,

$\$$ TL,DEPTH,RCSHST,TGW,FGROS,FL,WLV,WST,

$\$$ DAY,HAR,HARDAY,HARDEP,DTGA,IRS)

*-----If harvesting takes place, weights various plant organs must be recalculated

* (TWLG1,TWSG1,TWRG1,TW)

IF(HAR .EQ. 1. AND. DAY .EQ. HARDAY) THEN

$\mathrm{TWLG1}=\mathrm{FLV} * \mathrm{TGW}$

TWSG1 $=$ FST $*$ TGW

TWRG1 $=$ FRT $*$ TGW

$\mathrm{TW}=\mathrm{TGW}+(\mathrm{TWLD} 1+\mathrm{TWSD} 1+\mathrm{TWRD} 1+\mathrm{TWLD} 2+\mathrm{TWSD} 2+\mathrm{TWRD} 2+\mathrm{TWLD} 3+\mathrm{TWSD} 3+\mathrm{TWRD} 3$ ENDIF

*-----Conversion assimilated $\mathrm{CO} 2$ to $\mathrm{CH} 2 \mathrm{O}$

GPHOT $=$ DTGA $* 30 . / 44$.

*-.---Induction of flowering at DVS=1; flowering occurs 10 days after induction

* Induction of flowering, translocation and senescence occur simultaneously

IF (DVS .GE. 1.0)THEN

*-----If there is no above-ground plant biomass present, TRANS1 must stay at zero; otherwise it gets

* a value

IF ((TWLG1+TWSG1+TWRG1) .GT. 0.0)THEN

IF (TGW .GE. TWGRIZ) THEN

TRANS1 $=$ CVT $*$ GPHOT $*((T W L G 1+T W S G 1+T W R G 1) /$ 


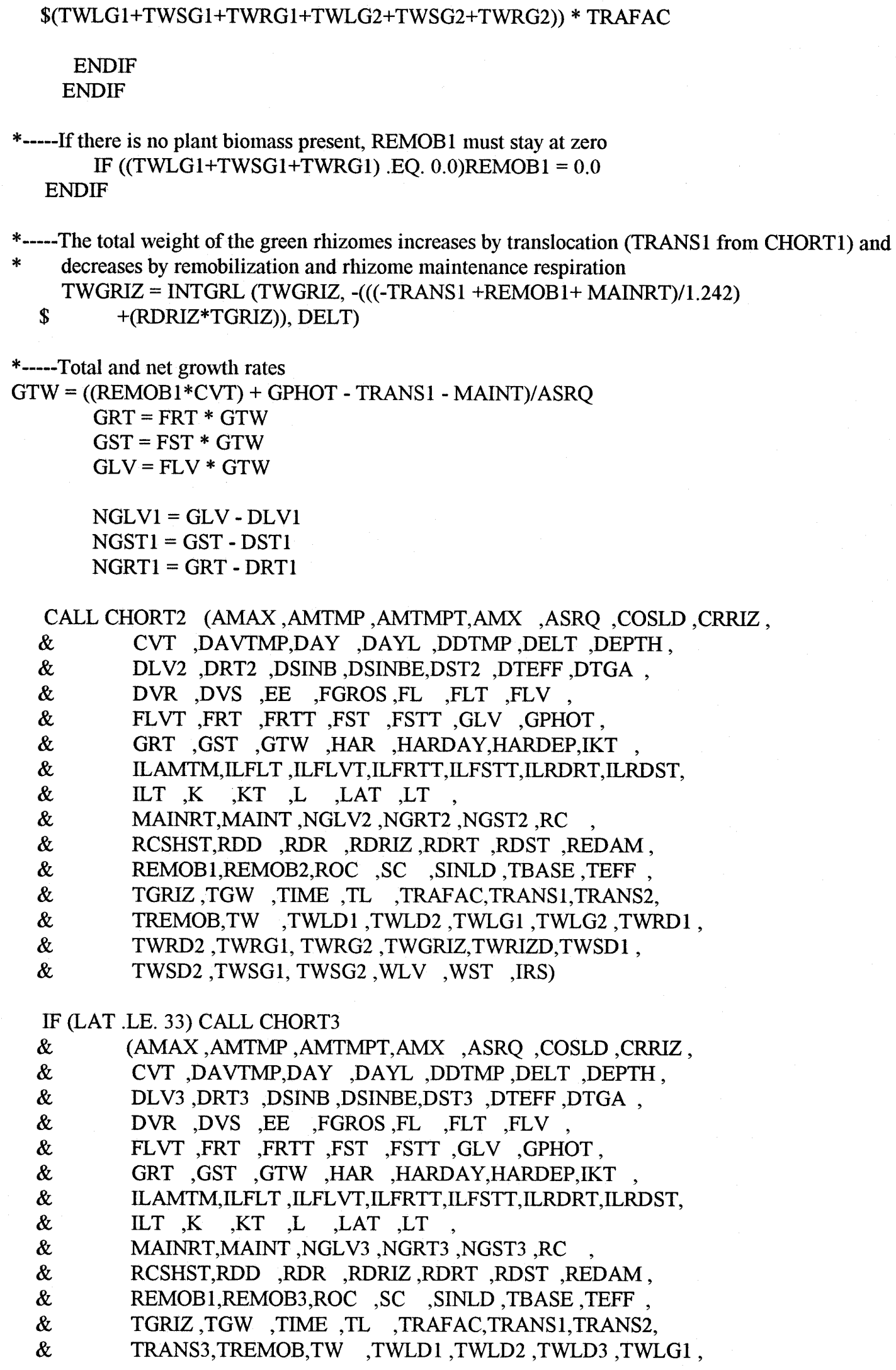




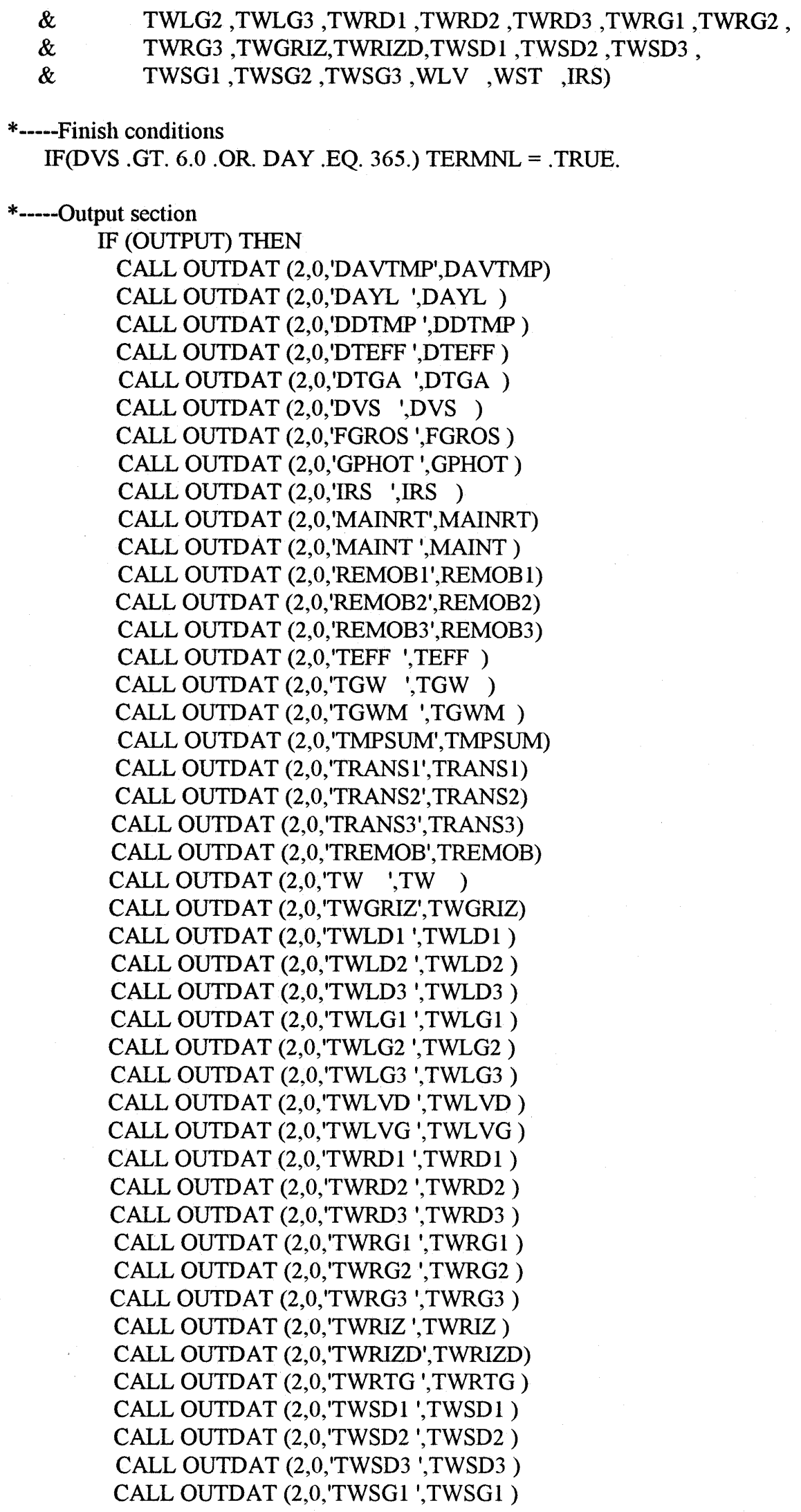


CALL OUTDAT $(2,0$, 'TWSG2 ',TWSG2 )

CALL OUTDAT $(2,0$, 'TWSG3 ',TWSG3 )

CALL OUTDAT $(2,0$, 'TWSTD ',TWSTD )

CALL OUTDAT $(2,0$, 'TWSTG ',TWSTG )

CALL OUTDAT $\left(2,0,{ }^{\prime}\right.$ WTMP ',WTMP )

END IF

ELSE IF (ITASK.EQ.3) THEN

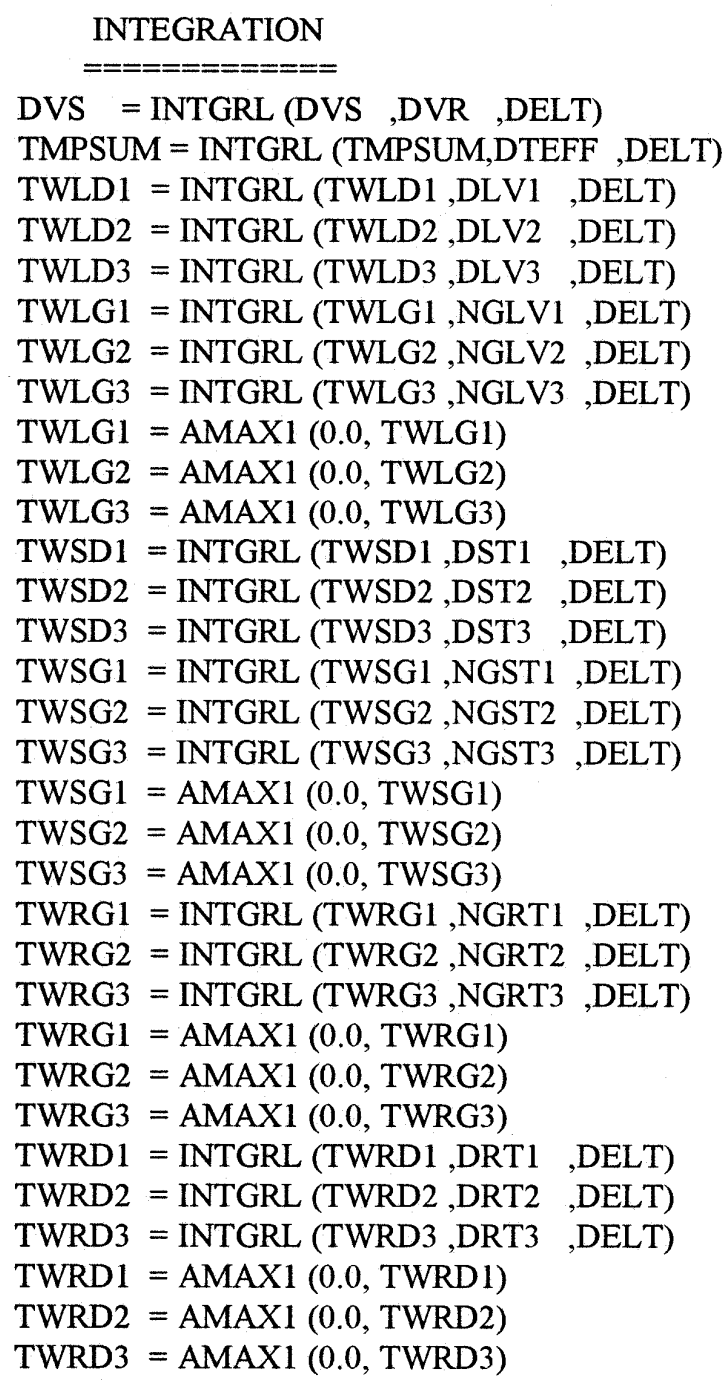

*-----If REMOB1 equals zero and TRANS1 equals zero and DVS greater that one, all biomass of

* cohort 1 is added to Cohort 2. Therefore all biomass in cohort 1 is gone \& shouldn't come back IF (DVS.GT.1.0 .AND. REMOBI.EQ.0.0 .AND. TRANSI.EQ.0.0)THEN

TWLG2 $=$ TWLG2 + TWLG1

TWRG2 $=$ TWRG2 + TWRG1

TWSG2 $=$ TWSG $2+$ TWSG1

TWLG1 $=0.0$

TWSG1 $=0.0$

TWRG1 $=0.0$ 
ENDIF

*----If REMOB2 equals zero and TRANS2 equals zero and DVS greater that two, all biomass of cohort

* $\quad 2$ is added to cohort 3. Therefore all biomass in cohort 2 is gone \& shouldn't come back

IF (DVS.GT.2.0.AND.REMOB2.EQ.0.0.AND.TRANS2.EQ.0.0.AND.LAT.LE.33) \&THEN

TWLG3 $=$ TWLG3 + TWLG2

TWRG3 $=$ TWRG $3+$ TWRG2

TWSG3 $=$ TWSG3 + TWSG2

TWLG2 $=0.0$

TWSG2 $=0.0$

TWRG2 $=0.0$

ENDIF

*-----Total plant weights

TWLVG $=$ TWLG1 + TWLG2 + TWLG3

TWLVD = TWLD1 + TWLD2 + TWLD3

TWRTG $=$ TWRG1 + TWRG2 + TWRG3

TWRTD $=$ TWRD $1+$ TWRD2 + TWRD 3

TWSTG $=$ TWSG1 + TWSG2 + TWSG 3

TWSTD $=$ TWSD $1+$ TWSD $2+$ TWSD 3

ELSE IF (ITASK.EQ.4) THEN

* TERMINAL SECTION

* $=============$

*.-----Terminal calculations

*.---.-Terminal output

CLOSE (IUNITD)

END IF

ITOLD $=$ ITASK

RETURN

END 


\begin{tabular}{|c|c|c|c|c|}
\hline $\begin{array}{l}* * * \\
*\end{array}$ & 3.1 ASTRO & & & $* * *$ \\
\hline * SUBROU & E ASTRO & & & * \\
\hline * Authors: I & el van Kraalingen & & & * \\
\hline * Date : 9 & ust 1987 & & & $*$ \\
\hline * Modified & an Goudriaan 4 Febr 1988 & & & $*$ \\
\hline * Modified & an Goudriaan and Kees Spitters 7 December 1 & & & $*$ \\
\hline $\begin{array}{l}* \\
*\end{array}$ & $\begin{array}{l}\text { is subroutine calculates astronomic day lengtl } \\
\text { (PE report \#?) and diurnal radiation characte }\end{array}$ & $\begin{array}{l}\text { dic day lengt } \\
\text { tily integral }\end{array}$ & & $*$ \\
\hline $\begin{array}{l}* \quad \text { sine of } \\
* \quad \text { find atn }\end{array}$ & $\begin{array}{l}\text { elevation, solar constant. Measured daily tota } \\
\text { eeric transmissivity and fraction diffuse radia }\end{array}$ & tion is used $t$ & & * \\
\hline * FORMAL & RAMETERS: $(\mathrm{I}=$ input, $\mathrm{O}=$ output, $\mathrm{C}=$ control, $\mathrm{I}$ & & & * \\
\hline * name & meaning & units & class & $*$ \\
\hline * -..-- & 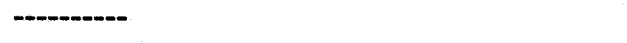 & ----- & $-\cdots$ & $-*$ \\
\hline * DAY & Day number $($ Jan 1 st $=1)$ & - & I & * \\
\hline * LAT & Latitude of the site & degrees & I & $*$ \\
\hline * DTR & Measured daily total global radiation & $\mathrm{J}$ m-2 d-1 & I & $*$ \\
\hline$* \mathrm{SC}$ & Solar constant & $\mathrm{J} \mathrm{m}-2 \mathrm{~s}-1$ & $\mathrm{O}$ & * \\
\hline * DS0 & Daily extraterrestrial radiation & $\mathrm{J} \mathrm{m}-2 \mathrm{~d}-1$ & $\mathrm{O}$ & $*$ \\
\hline * SINLD & Seasonal offset of sine of solar height & - & $\mathrm{O}$ & * \\
\hline * COSLD & Amplitude of sine of solar height & - & $\mathrm{O}$ & * \\
\hline * DAYL & Astronomical day length (base $=0$ degrees) & $\mathrm{h}$ & $\mathrm{O}$ & * \\
\hline * DSINB & Daily total of sine of solar height & $\mathbf{s}$ & $\mathrm{O}$ & * \\
\hline * DSINBE & Daily total of effective solar height & s & $\mathrm{O}$ & \\
\hline $\begin{array}{l}* \text { FATAL E } \\
* \text { condition }\end{array}$ & R CHECKS (execution terminated, message) & & & * \\
\hline & & & & \\
\hline$*$ LAT $>67$ & $T<-67$ & & & * \\
\hline & & & & * \\
\hline * SUBROU & ES and FUNCTIONS called : none & & & $*$ \\
\hline * FILE usą & one & & & * \\
\hline
\end{tabular}

\section{SUBROUTINE ASTRO (DAY,LAT,SC,DS0,SINLD,COSLD, $\$ \quad$ DAYL,DSINB,DSINBE) \\ IMPLICIT REAL (A-Z)}

*.---.PI and conversion factor from degrees to radians PARAMETER ( $\mathrm{PI}=3.141592654, \mathrm{RAD}=0.017453292$ )

*-----Check on input range of parameters

IF (LAT.GT.67.) STOP 'ERROR IN ASTRO: LAT $>67$ '

IF (LAT.LT.-67.) STOP 'ERROR IN ASTRO: LAT <-67'

*-----Declination of the sun as function of daynumber (DAY) $\mathrm{DEC}=-\mathrm{ASIN}\left(\operatorname{SIN}(23.45 * \mathrm{RAD}) * \operatorname{COS}\left(2 .{ }^{*} \mathrm{PI} *(\mathrm{DAY}+10) / 365.\right)\right)$

*----SINLD, COSLD and AOB are intermediate variables

SINLD $=$ SIN(RAD*LAT) $*$ SIN(DEC)

COSLD $=$ COS $($ RAD $*$ LAT $) * \operatorname{COS}(\mathrm{DEC})$

$\mathrm{AOB}=\mathrm{SINLD} / \mathrm{COSLD}$ 


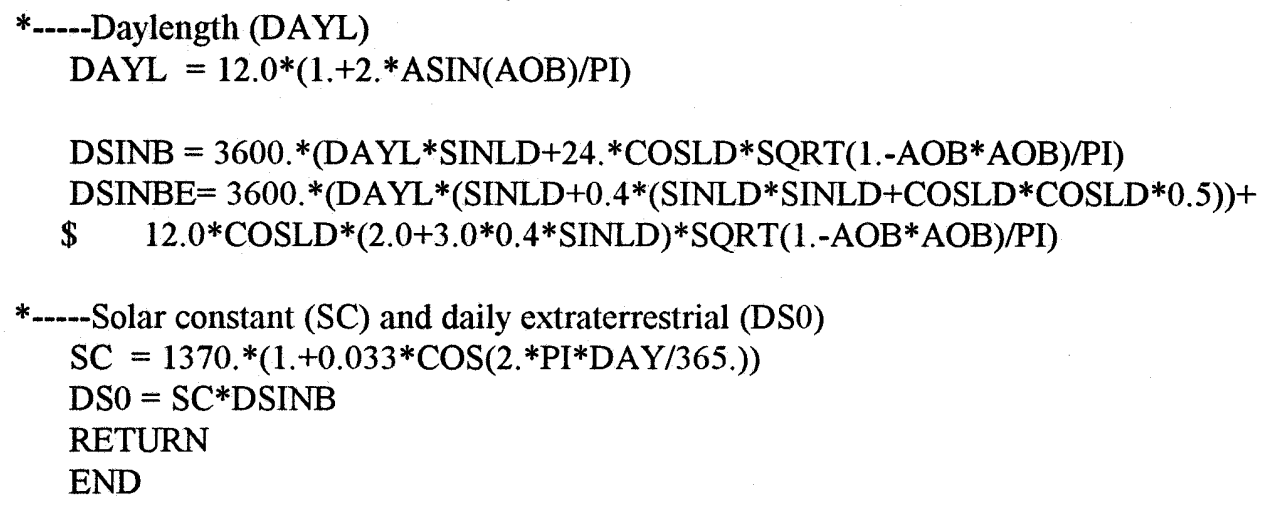




\begin{tabular}{|c|c|c|c|c|}
\hline $\begin{array}{l}* * * \\
*\end{array}$ & 3.2 TOTASS & & & \\
\hline * SUBROUTI & ETOTASS & & & $*$ \\
\hline * Authors: Da & el van Kraalingen & & & * \\
\hline * Date : $10 \mathrm{D}$ & cember 1987 & & & $*$ \\
\hline * Modified by & In Goudriaan 5 February 1988 & & & $*$ \\
\hline * Modified by & In Goudriaan and Kees Spitters 7 December 1989 & & & $*$ \\
\hline * Units modif & by Elly Best \& Will Boyd 28 July 1995 & & & $*$ \\
\hline * $\quad$ Purpose: ' & is subroutine calculates daily total gross assimilation (DTGA) & by performing a & & $*$ \\
\hline * Gaussian & tegration over time. At three different times of the day, radiatio & on is computed & & $*$ \\
\hline * $\quad$ and used & determine assimilation whereafter integration takes place. (Sou & urce: Post-gradua & late & * \\
\hline * $\quad$ Course 'S & ulation of plant growth and crop production. Pontignano, Sien & a, Italy; 3-12 & & $*$ \\
\hline * Novembe & 1992. Dept. Theor. Production Ecol. (TPE-WAU), Wageningen & n Agricultural & & $*$ \\
\hline University & and DLO-Centre for Agrobiological Research (CABO-DLO).) & & & $*$ \\
\hline$\uparrow$ & & & & $*$ \\
\hline * FORMAL P & RAMETERS: ( $\mathrm{I}=$ input, $\mathrm{O}=$ output, $\mathrm{C}=$ control, $\mathrm{IN}=$ init, $\mathrm{T}=$ time $)$ & & & * \\
\hline * name & meaning & units & class & $*$ \\
\hline * ----- & --n-- & ---- & & * \\
\hline$* \mathrm{SC}$ & Solar constant & $\mathrm{J} \mathrm{m}-2 \mathrm{~s}-1$ & I & $*$ \\
\hline * DAYL & Day length (base $=0$ degrees) & h & I & $*$ \\
\hline * SINLD & Intermediate variable in calculating solar declination & - & I & $*$ \\
\hline * COSLD & Intermediate value in calculating solar height & - & I & $*$ \\
\hline * DSINBE & Daily total of effective solar height & $\mathbf{s}$ & I & * \\
\hline * DTR & Measured daily total of global radiation & $\mathrm{J} / \mathrm{m} 2 / \mathrm{d}$ & I & $*$ \\
\hline * $\mathrm{RC}$ & Reflection coefficient of irradiation at water surface (relative) & & I & $*$ \\
\hline * L & Water type specific light extinction coefficient & - & I & $*$ \\
\hline$* \mathrm{~K}$ & Plant species specific light extinction coefficient & - & I & $*$ \\
\hline * AMAX & Assimilation rate at light saturation for individual shoots & $\mathrm{g} \mathrm{CO} 2 / \mathrm{g} \mathrm{DW} / \mathrm{h}$ & I & * \\
\hline * $\mathrm{EE}$ & Initial light use efficiency for individual shoots & $\mathrm{g} \mathrm{CO} 2 / \mathrm{J}$ & I & $*$ \\
\hline * TL & Thickness per plant layer & m & I & $*$ \\
\hline * DEPTH & Water depth & m & I & $*$ \\
\hline * RCHSHST & Relation coefficient shoot weight-stem length & $\mathrm{m} / \mathrm{g} \mathrm{DW}$ & I & $*$ \\
\hline * TGW & Total live plant dry weight & $\mathrm{g} \mathrm{DW} / \mathrm{m} 2$ & I & * \\
\hline * FGROS & Instantaneous assimilation rate of whole canopy & $\mathrm{g} \mathrm{CO} 2 / \mathrm{m} 2$ soil/1 & $/ \mathrm{hO}$ & * \\
\hline * FL & Leaf dry matter allocation to each layer of plant & - & I & * \\
\hline * WLV & Dry weight of leaves & $\mathrm{g} \mathrm{DW} / \mathrm{m} 2$ & I & $*$ \\
\hline * WST & Dry weight of stems & $\mathrm{g} \mathrm{DW} / \mathrm{m} 2$ & I & $*$ \\
\hline * HAR & Harvesting & - & I & $*$ \\
\hline * HARDAY & Harvesting day number & d & I & $*$ \\
\hline * HARDEP & Harvesting depth & m & I & $*$ \\
\hline * DTGA & Daily total gross assimilation & $\mathrm{g} \mathrm{CO} 2 / \mathrm{m} 2 / \mathrm{d}$ & $\mathrm{O}$ & * \\
\hline * SUBROUTI & ES and FUNCTIONS called : ASSIM & & & \\
\hline * FILE usage & & & & \\
\hline
\end{tabular}

\footnotetext{
SUBROUTINE TOTASS (SC,DAYL,SINLD,COSLD,DSINBE,DTR,RC,L,K, $\$ \quad$ AMAX,EE,TL,DEPTH,RCSHST,TGW,FGROS,FL, WLV,WST,DAY,HAR,HARDAY,HARDEP,DTGA,IRS)

IMPLICIT REAL(A-Z)

REAL XGAUSS(3), WGAUSS(3)
} 
INTEGER II, IGAUSS

PARAMETER $(\mathrm{PI}=3.141592654)$

DATA IGAUSS $/ 3 /$

DATA XGAUSS $/ 0.1127,0.5000,0.8873 /$

DATA WGAUSS $/ 0.2778,0.4444,0.2778 /$

*-----Assimilation set to zero \& three different times of the day (HOUR) $\mathrm{DTGA}=0$. DO 10 II $=1$,IGAUSS

*-----At the specified HOUR, radiation is computed and used to compute assimilation HOUR $=12.0+\mathrm{DAYL} * 0.5 *$ XGAUSS(II)

*-----Sine of solar elevation

$\mathrm{SINB}=\operatorname{AMAX1}(0 ., \operatorname{SINLD}+\operatorname{COSLD} * \operatorname{COS}(2 . * \mathrm{PI}(\mathrm{HOUR}+12) / 24)$.

*-----Diffuse light fraction (FRDIF) from atmospheric transmission (ATMTR)

PAR $=0.5 * D T R * \operatorname{SINB} *(1 .+0.4 * \operatorname{SINB}) / \mathrm{DSINBE}$

ATMTR $=$ PAR $/(0.5 *$ SC $*$ SINB $)$

FRDIF $=1.47-1.66 *$ ATMTR

IF (ATMTR.LE.0.35.AND.ATMTR.GT.0.22) FRDIF=1.-6.4*(ATMTR-0.22)**2

IF (ATMTR.LE.0.22) FRDIF=1.

FRDIF $=$ AMAXl(FRDIF, $0.15+0.85 *(1 .-\mathrm{EXP}(-0.1 / \mathrm{SINB})))$

*-----Diffuse PAR (PARDIF) and direct PAR (PARDIR)

PAR $=0.5 * \mathrm{DTR} * \mathrm{SINB}^{*}(1 .+0.4 * \mathrm{SINB}) / \mathrm{DSINBE}$

PARDIF $=$ MIN $($ PAR,SINB $*$ FRDIF*ATMTR $* 0.5 *$ SC $)$

PARDIR $=$ PAR-PARDIF

CALL ASSIM

\$ (PARDIR,PARDIF,RC,L,K,AMAX,EE,TL,DEPTH,RCSHST,TGW, \$ FL,WLV,WST,DAY,HAR,HARDAY,HARDEP,II,FGROS,IRS)

*-----Integration of assimilation rate to a daily total (DTGA)

DTGA $=$ DTGA+FGROS $*$ WGAUSS(II)

10 CONTINUE

DTGA $=$ DTGA $*$ DAYL

RETURN

END 


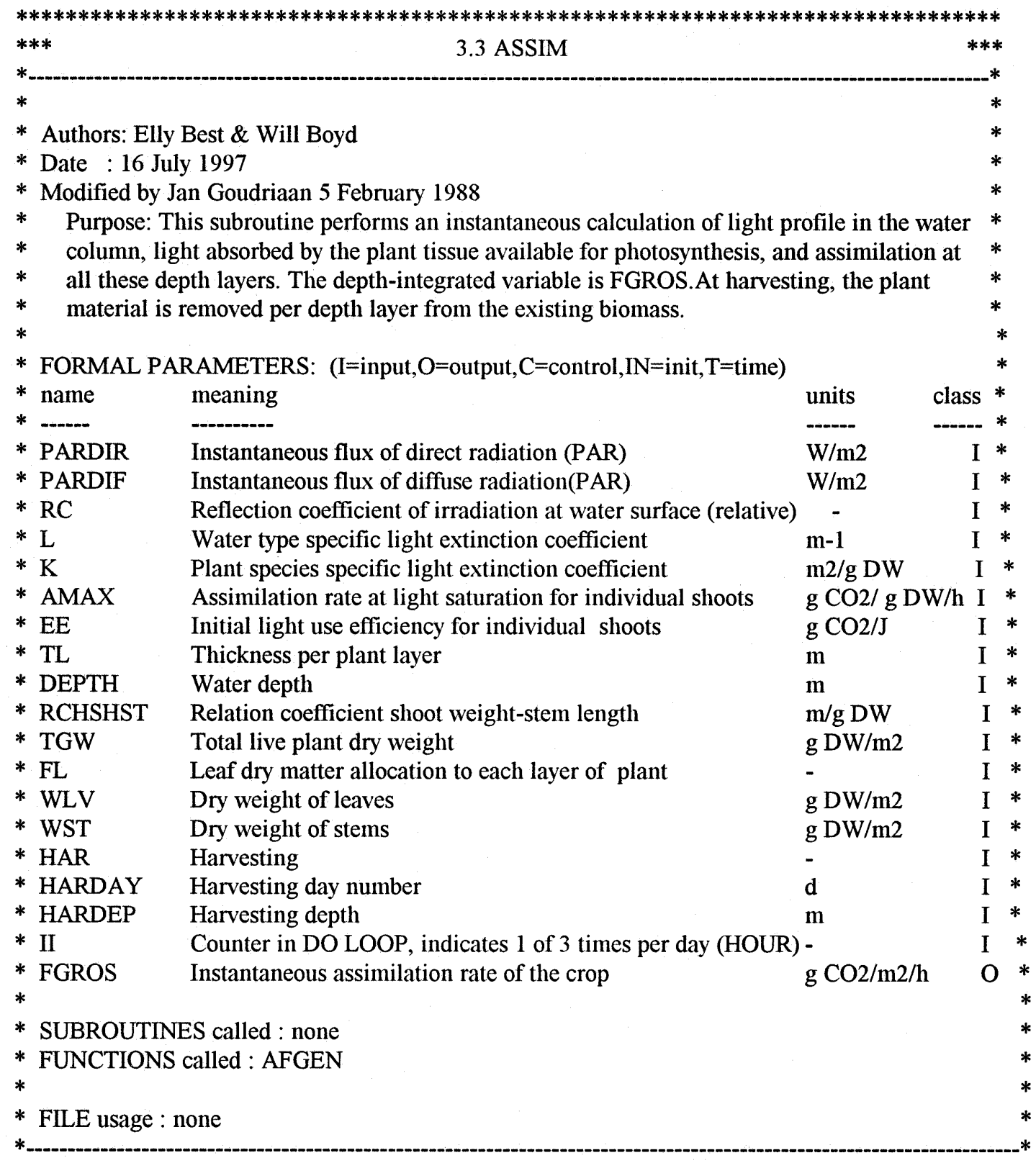

\section{SUBROUTINE ASSIM (PARDIR,PARDIF,RC,L,K,AMAX,EE,TL, $\$$ DEPTH,RCSHST,TGW,FL,WLV,WST,DAY, $\$ \quad$ HAR,HARDAY,HARDEP,II,FGROS,IRS)}

\section{IMPLICIT REAL(A-Z)}

REAL DMPC(6), SC(100), IRZ(100), IABS(100), IABSL(100)

REAL HIG(100), AH(100), REDF(100), SumZ, BotBio

INTEGER IMN1, IRED, I, LOOP, Layers, LBelow, ILAY, II

PARAMETER $(\mathrm{IMN} 1=40)$

REAL REDFT(IMN1), DMPCT(IMN1)

*-----Read AFGEN functions

CALL RDAREA ('REDFT ',REDFT ,IMN1 ,IRED ) 
CALL RDAREA ('DMPCT ',DMPCT, IMN1, ,ILAY )

*-----Irradiation just beneath the water surface

IRS = PARDIR + PARDIF

$\operatorname{IRZ}(1)=\operatorname{IRS} *(1.0-\mathrm{RC})$

*-.---Canopy assimilation is set to zero

FGROS $=0$.

*--.--Calculate stem length

STEMLE $=$ AMIN1 $($ Depth $+.0995,($ RCSHST $*($ WLV+WST $)))$

IF (STEMLE .GT. Depth+.08)THEN

*-----Determine total number of layers in the given water depth

LOOP $=$ INT $($ Depth/TL +0.1$)+1$

*-----LOOP should never be less than 6 since DEPTH shouldn't be less than $.5 \mathrm{~m}$ IF (LOOP .LE. 5) LOOP $=6$

*----Distribute $61 \%$ of total plant biomass in 1 st 5 layers

DO $10 \mathrm{I}=1,5$

$\mathrm{VAL}=\mathrm{REAL}(\mathrm{I})$

DMPC(I) $=$ LINT $($ DMPCT, ILAY, VAL)

$\mathrm{SC}(\mathrm{I})=\mathrm{TGW} * \mathrm{DMPC}(\mathrm{I})$

10 CONTINUE

*------If water depth is at least $1 \mathrm{~m}$ - use METHOD1 for distribution of

* biomass beyond 1st 5 layers; otherwise, use METHOD2

* METHOD 1

If (LOOP .GE. 10)THEN

*-----Distribute $39 \%$ of biomass in the lower layers (including last layer)

* with biomass gradually decreasing toward the bottom

* LOOP (integer) .. Number of $0.1 \mathrm{~m}$ water layers

* LAYERS (integer) .. Layers remaining after initial 5

*-----SUMZ (real) .. Summation of layers 6 through LOOP

*-----LBELOW (integer) .. Layer number going from bottom to top

*-----5 in next statement is for the 1st 5 layers of the plant

LAYERS $=$ LOOP -5

SUMZ $=($ LAYERS $/ 2.0) *($ LAYERS +1.0$)$

DO $20 \mathrm{I}=6, \mathrm{LOOP}$

LBELOW = LAYERS $-(\mathrm{I}-5)+1.0$

$\mathrm{SC}(\mathrm{I})=(\mathrm{LBELOW} / \mathrm{SUMZ}) *(\mathrm{TGW} * 0.39)$

20 CONTINUE

*-----METHOD 2

ELSE

*-----If water depth is less than $1 \mathrm{~m}$ - put $5 \%$ of total biomass in each layer

* remaining - subtract from the $39 \%$ biomass reserved for lower layers $\mathrm{BotBio}=\mathrm{TGW} * 0.39$ 


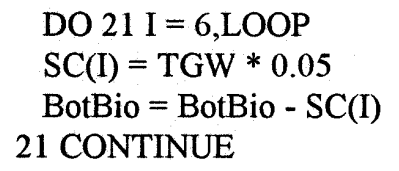

DO $21 \mathrm{I}=6, \mathrm{LOOP}$

$\mathrm{SC}(\mathrm{I})=\mathrm{TGW} * 0.05$

BotBio $=$ BotBio $-\mathrm{SC}(\mathrm{I})$

21 CONTINUE

*-----Redistribute difference "BotBio" over the top 5 layers proportionally

DO $22 \mathrm{I}=1,5$

$\mathrm{SC}(\mathrm{I})=\mathrm{SC}(\mathrm{I})+(\mathrm{DMPC}(\mathrm{I}) * \mathrm{BotBio})$

22 CONTINUE

ENDIF

*-----Harvesting

IF (HAR .EQ. 1. .AND. DAY .EQ. HARDAY)THEN

IF (HARDEP .GT. DEPTH) HARDEP = DEPTH

DO $25 \mathrm{I}=1, \mathrm{HARDEP} / .1$

$\mathrm{SC}(\mathrm{I})=0.0$

25 CONTINUE

*-----Reset total live weight (TGW) to zero

IF(II .EQ. 1)TGW $=0.0$

ENDIF

DO $50 \mathrm{I}=1, \mathrm{LOOP}$

*-----Total irradiation on top of stratum I

$\operatorname{IRZ}(\mathrm{I}+1)=\operatorname{IRZ}(\mathrm{I}) * \operatorname{EXP}(-\mathrm{TL} * \mathrm{~L}-\mathrm{K} * \mathrm{SC}(\mathrm{I}))$

$\mathrm{IF}(\mathrm{SC}(\mathrm{I}) . \mathrm{EQ}$. 0.0) GOTO 30

*-----Radiation absorbed by macrophyte community

$\operatorname{IABS}(\mathrm{I})=(\operatorname{IRZ}(\mathrm{I})-\mathrm{IRZ}(\mathrm{I}+1)) * \mathrm{SC}(\mathrm{I}) * \mathrm{~K} /(\mathrm{K} * \mathrm{SC}(\mathrm{I})+\mathrm{TL} * \mathrm{~L})$

*-----Radiation absorbed by leaves, excluding bottom layer IF(I .LT. LOOP) IABSL(I) $=$ IABS(I) * FL

IF(IABSL(I) .EQ. 0.0)GOTO 30

*-----Height on top of stratum I measured from the water surface $\mathrm{HIG}(\mathrm{I})=\mathrm{TL} *(\mathrm{LOOP}-\mathrm{I})$

*-----Absolute height of vegetation on top of stratum I, measured

* from the top of the plant $\mathrm{AH}(\mathrm{I})=$ STEMLE $-\mathrm{HIG}(\mathrm{I})$

*-----Reduction factor over the vertical of the vegetation $\operatorname{REDF}(\mathrm{I})=\mathrm{LINT}(\mathrm{REDFT}, \mathrm{IRED}, \mathrm{AH}(\mathrm{I}))$

*-----Instantaneous $\mathrm{CO} 2$ assimilation rate per depth layer $\mathrm{FGL}=\mathrm{SC}(\mathrm{I}) * \mathrm{AMAX} * \mathrm{REDF}(\mathrm{I}) *(1 .-\mathrm{EXP}(-\mathrm{EE} * \mathrm{IABSL}(\mathrm{I}) * 3600 . /$

$\$($ AMAX*REDF(I)*SC(I))))

GOTO 40

$30 \mathrm{FGL}=0.0$

40 FGROS $=$ FGROS + FGL

*-----If plants are harvested, live plant weight is recalculated 
IF (HAR.EQ.1 .AND. DAY.EQ.HARDAY .AND. II.EQ.1) THEN

$\mathrm{TGW}=\mathrm{TGW}+\mathrm{SC}(\mathrm{I})$

ENDIF

50 CONTINUE

ENDIF

\section{RETURN}

END

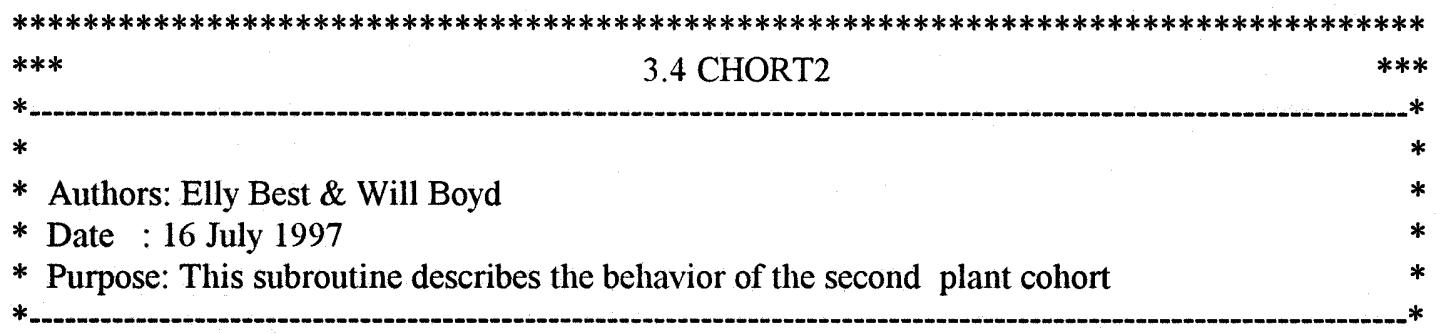

SUBROUTINE CHORT2(AMAX ,AMTMP ,AMTMPT,AMX ,ASRQ ,COSLD,CRRIZ,

\& $\quad$ CVT ,DAVTMP,DAY ,DAYL ,DDTMP ,DELT ,DEPTH,

\& DLV2 ,DRT2 ,DSINB,DSINBE,DST2 ,DTEFF, DTGA ,

\& DVR ,DVS ,EE ,FGROS ,FL ,FLT ,FLV ,

\& $\quad$ FLVT ,FRT ,FRTT ,FST ,FSTT ,GLV ,GPHOT,

$\& \quad$ GRT ,GST ,GTW ,HAR ,HARDAY,HARDEP,IKT ,

\& ILAMTM,ILFLT, ILFLVT,ILFRTT,ILFSTT,ILRDRT,ILRDST,

$\& \quad$ ILT ,K ,KT ,L ,LAT ,LT ,

\& $\quad$ MAINRT,MAINT ,NGLV2,NGRT2,NGST2 ,RC ,

\& RCSHST,RDD ,RDR ,RDRIZ,RDRT ,RDST ,REDAM,

\& REMOB1,REMOB2,ROC ,SC ,SINLD, TBASE, TEFF,

\& TGRIZ, TGW ,TIME, TL ,TRAFAC,TRANS1,TRANS2,

\& TREMOB,TW ,TWLD1, TWLD2, TWLG1, TWLG2,TWRD1,

\& $\quad$ TWRD2, TWRG1, TWRG2, TWGRIZ,TWRIZD,TWSD1,

\& TWSD2,TWSG1, TWSG2,WLV ,WST ,IRS)

IMPLICIT REAL (A-Z)

*.----Formal parameters

INTEGER IKT ,ILAMTM,ILFLT ,ILFLVT,ILFRTT,ILFSTT

INTEGER ILRDRT,ILRDST,ILT

LOGICAL OUTPUT, TERMNL

IF (DVS .LT. 1.0) GOTO 100

*----Call to SBRT ASTRO to introduce day length into MAIN for tentative

* relationship REMOB2-DAYL; otherwise this call can be made at *ASTROOO

CALL ASTRO

\$ (DAY,LAT,SC,DS0,SINLD,COSLD,DAYL,DSINB,DSINBE)

*----Calculation of dry matter and its partitioning over the plant organs

$\mathrm{TW}=\mathrm{TGW}+(\mathrm{TWLD} 1+\mathrm{TWSD} 1+\mathrm{TWRD} 1+\mathrm{TWLD} 2+\mathrm{TWSD} 2+\mathrm{TWRD} 2)$

FLV $=$ LINT(FLVT, ILFLVT,DVS)

FST $=$ LINT(FSTT, ILFSTT,DVS)

FRT $=$ LINT(FRTT, ILFRTT,DVS)

FL $=$ LINT(FLT ,ILFLT ,DVS) 
*-----Growth of plant organs, maintenance respiration and translocation

* Calculation assimilate requirement for plant organ formation.

ASRQ $=1.54$

MAINTS $=0.016 *$ TWLG2 $+0.01 *$ TWSG2 $+0.015 *$ TWRG2

MAINT $=$ MAINTS $*$ TEFF

MAINRT $=0.005 *$ TWGRIZ $*$ TEFF

*-----Carbohydrate behavior: remobilization from rhizomes for plant formation at proper day length

* and temperature conditions (presently related to DVS); translocation from plants to form

* rhizomes, provided plants are present

TRANS2 $=0.0$

TREMOB $=0.0$

TWGRIZ $=$ AMAXI (CRRIZ, TWGRIZ)

TGRIZ $=$ TWGRIZ

TWRIZD = INTGRL $($ TWRIZD, RDRIZ , DELT $)$

IF (DVS.GE.1.0 .AND. DVS.LT.1.63) THEN

IF (GPHOT .LT. MAINT) THEN

IF (TWGRIZ .GT. CRRIZ) THEN

TREMOB $=$ INTGRL $($ TREMOB, REMOB2, DELT $)$

REMOB2 $=$ ROC $*$ TWGRIZ

ELSE

WRITE $(*, *)^{\prime}$ Vegetation is dying '

REMOB2 $=0.000001$

ENDIF

ENDIF

ELSE

REMOB2 $=0.000001$

ENDIF

*-----If the carbohydrates fill the rhizomes by TRANS1 from cohort1, REMOB1 stays zero; TRANS2

* remains zero, if the carbohydrates leave the rhizomes by REMOB2 to form the plants of cohort

* but also if no plant biomass of cohort2 is present. The plants of cohort2 are formed by REMOB2

* only at a certain DVS

IF (TRANS1 .GT. 0.0)REMOB $1=0.0$

IF (DVS .GE. 2.0)REMOBI $=0.0$

IF (DVS .GE. 2.0)TRANS1 $=0.0$

IF (REMOB2 .GT. 0.000001) TRANS2 $=0.0$

*-----Relative death rates

RDR = INSW (DVS-2.001,0., LINT(RDRT,ILRDRT,DDTMP))

RDS = INSW (DVS-2.001,0., LINT(RDST,ILRDST,DDTMP))

*-----Development rates

IF(DAVTMP .LT. 3.0) THEN

$\mathrm{DVR}=0.0$

ELSE IF (DVS.LE.1.) THEN

$\mathrm{DVR}=0.022 * \mathrm{DAVTMP} / 30$

ELSE IF (DVS.LE.6.0) THEN

$\mathrm{DVR}=0.015 * \mathrm{DAVTMP} / 30$

ENDIF 
*-----Calculation of effective daytime temperature DTEFF $=$ AMAX1 $(0 ., D A V T M P-T B A S E)$

*-----Calculation of dead plant material per organ

$$
\begin{aligned}
& \text { DLV2 }=\text { TWLG2 } * \text { RDR } \\
& \text { DST2 }=\text { TWSG2 } * \text { RDR } \\
& \text { DRT2 }=\text { TWRG2 } * \text { RDR }
\end{aligned}
$$

*-----Shoot photosynthesis at light saturation and daytime temperature effect on shoot photosynthesis AMAX = AMAX1 $(0.00001, \mathrm{AMX} *$ AMTMP $)$

AMAX $=$ AMAX $*$ REDAM

AMTMP $=$ LINT(AMTMPT,ILAMTM,DDTMP)

*-----Before calling TOTASS, determine light extinction coefficients of plants $(\mathrm{K})$ and of water $(\mathrm{L})$

$\mathrm{L}=$ LINT(LT,ILT,TIME)

$\mathrm{K}=\mathrm{LINT}(\mathrm{KT}, \mathrm{IKT}, \mathrm{DVS})$

*-----Daily total gross assimilation

CALL TOTASS

\$ (SC,DAYL,SINLD,COSLD,DSINBE,RDD,RC,L,K,AMAX,EE,

\$ TL,DEPTH,RCSHST,TGW,FGROS,FL,WLV,WST,

\$ DAY,HAR,HARDAY,HARDEP,DTGA,IRS)

*-----If harvesting takes place, weights various plant organs must be recalculated

* (TWLVG,TWSTG,TWRTG,TW)

IF(HAR .EQ. 1. AND. DAY .EQ. HARDAY) THEN

TWLG2 $=$ FLV $*$ TGW

TWSG2 $=$ FST $*$ TGW

TWRG2 $=$ FRT $*$ TGW

TW $=$ TGW + (TWLD1+TWSD1+TWRD1+TWLD2+TWSD2+TWRD2) ENDIF

*-----Conversion assimilated $\mathrm{CO} 2$ to $\mathrm{CH} 2 \mathrm{O}$ $\mathrm{GPHOT}=\mathrm{DTGA} * 30 . / 44$.

*-----Induction of flowering at DVS=2; flowering occurs 10 days after induction.

* Induction of flowering, translocation and senescence occur simultaneously .

IF (DVS .GE. 1.63)THEN

IF ((TWLG2+TWSG2+TWRG2) .GT. 0.0)THEN

IF (TGW .GE. TWGRIZ) THEN

IF (TRANSI .EQ. 0.0) THEN

TRANS2 $=$ CVT $*$ GPHOT $*((T W L G 2+$ TWSG2+TWRG2 $) /$

\$ (TWLG1+TWSG1+TWRG1+TWLG2+TWSG2+TWRG2)) * TRAFAC

\section{ENDIF \\ ENDIF}

ENDIF

*-----If there is no plant biomass REMOB2 must stay at zero

IF ((TWLG2+TWSG2+TWRG2) .EQ. 0.0)REMOB2 $=0.0$

ENDIF 
* -..--When TRANS2 gets a value set REMOB2 to 0

If (TRANS2 .GT. 0.0)REMOB2 $=0.0$

*-----The total weight of the green rhizomes increases by translocation (TRANS2 from CHORT2)

* and decreases by remobilization and rhizome maintenance respiration

TWGRIZ = INTGRL (TWGRIZ, -(((-TRANS2 +REMOB2+ MAINRT)/1.242)

$\$ \quad+($ RDRIZ*TGRIZ)), DELT)

*-----Total and net growth rates

GTW $=(($ REMOB2 $*$ CVT $)+$ GPHOT - TRANS2 - MAINT $) /$ ASRQ

$\mathrm{GRT}=\mathrm{FRT} * \mathrm{GTW}$

$\mathrm{GST}=\mathrm{FST} * \mathrm{GTW}$

$\mathrm{GLV}=\mathrm{FLV} * \mathrm{GTW}$

$\mathrm{NGLV} 2=\mathrm{GLV}-\mathrm{DLV} 2$

NGST2 = GST - DST2

NGRT2 $=$ GRT - DRT2

100 RETURN

END

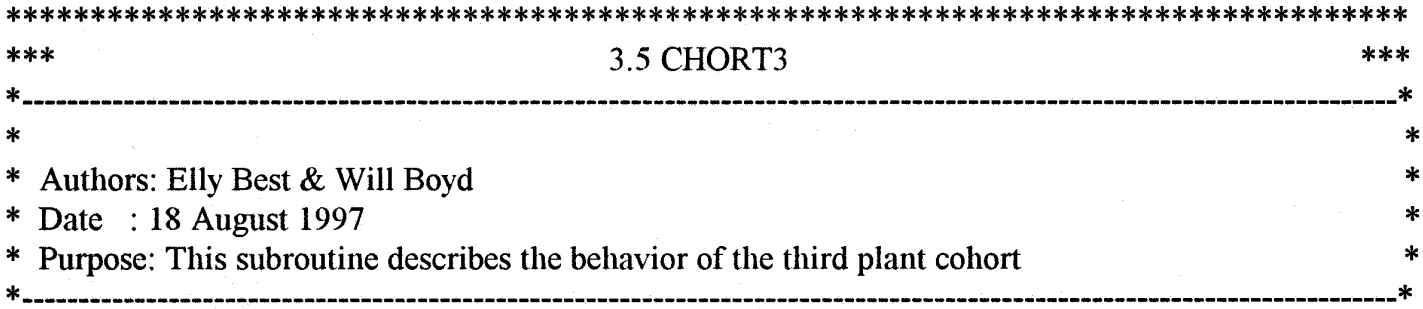

SUBROUTINE CHORT3(AMAX ,AMTMP ,AMTMPT,AMX ,ASRQ ,COSLD,CRRIZ,

\& CVT ,DAVTMP,DAY ,DAYL ,DDTMP ,DELT ,DEPTH,

\& DLV3 ,DRT3 ,DSINB ,DSINBE,DST3 ,DTEFF ,DTGA ,

\& DVR ,DVS ,EE ,FGROS ,FL ,FLT ,FLV ,

\& FLVT ,FRT ,FRTT ,FST ,FSTT ,GLV ,GPHOT,

\& GRT ,GST ,GTW ,HAR ,HARDAY,HARDEP,IKT ,

\& ILAMTM,ILFLT ,ILFLVT,ILFRTT,ILFSTT,ILRDRT,ILRDST,

$\& \quad \mathrm{ILT}, \mathrm{K}, \mathrm{KT}, \mathrm{L}, \mathrm{LAT}, \mathrm{LT}$,

\& $\quad$ MAINRT,MAINT ,NGLV3 ,NGRT3 ,NGST3 ,RC ,

\& RCSHST,RDD ,RDR ,RDRIZ,RDRT ,RDST ,REDAM,

\& REMOB1,REMOB3,ROC ,SC ,SINLD, TBASE, TEFF ,

\& TGRIZ, TGW ,TIME, TL ,TRAFAC,TRANSI,TRANS2,

\& TRANS3,TREMOB,TW ,TWLD1, TWLD2, TWLD3, TWLG1,

\& $\quad$ TWLG2, TWLG3 ,TWRD1 ,TWRD2, TWRD3, TWRG1 ,TWRG2,

\& $\quad$ TWRG3, TWGRIZ,TWRIZD,TWSD1, TWSD2, TWSD3,

\& TWSG1, TWSG2, TWSG3,WLV ,WST ,IRS)

IMPLICIT REAL (A-Z)

*-----Formal parameters

INTEGER IKT ,ILAMTM,ILFLT ,ILFLVT,ILFRTT,ILFSTT

INTEGER ILRDRT,ILRDST,ILT

LOGICAL OUTPUT, TERMNL 
IF (DVS .LT. 2.0) GOTO 100

*----Call to SBRT ASTRO to introduce day length into MAIN for tentative

* relationship REMOB3-DAYL; otherwise this call can be made at *ASTROOO

CALL ASTRO

\$ (DAY,LAT,SC,DS0,SINLD,COSLD,DAYL,DSINB,DSINBE)

*-----Calculation of dry matter and its partitioning over the plant organs

$\mathrm{TW}=\mathrm{TGW}+(\mathrm{TWLD} 1+\mathrm{TWSD} 1+\mathrm{TWRD} 1+\mathrm{TWLD} 2+\mathrm{TWSD} 2+\mathrm{TWRD} 2+\mathrm{TWLD} 3+\mathrm{TWSD} 3+\mathrm{TWRD} 3)$

FLV $=$ LINT(FLVT ,ILFLVT,DVS)

FST $=$ LINT(FSTT, ILFSTT,DVS)

FRT $=$ LINT(FRTT, ILFRTT,DVS)

$\mathrm{FL}=$ LINT(FLT, ILFLT, DVS)

*-----Growth of plant organs, maintenance respiration and translocation

* Calculation assimilate requirement for plant organ formation.

ASRQ $=1.54$

MAINTS $=0.016 *$ TWLG3 $+0.01 *$ TWSG3 $+0.015 *$ TWRG3

MAINT $=$ MAINTS $*$ TEFF

MAINRT $=0.005 *$ TWGRIZ $*$ TEFF

*-.---Carbohydrate behavior: remobilization from rhizomes for plant formation at proper day length and

* temperature conditions (presently related to DVS); translocation from plants to form rhizomes,

* provided plants are present

TRANS3 $=0.0$

TREMOB $=0.0$

TWGRIZ = AMAXI (CRRIZ, TWGRIZ)

TGRIZ $=$ TWGRIZ

TWRIZD = INTGRL $($ TWRIZD, RDRIZ , DELT)

IF (DVS.GE.2.0 .AND. DVS.LT.2.447) THEN

IF (GPHOT .LT. MAINT) THEN

IF (TWGRIZ .GT. CRRIZ) THEN

TREMOB $=$ INTGRL $($ TREMOB, REMOB3, DELT $)$

REMOB3 $=$ ROC $*$ TWGRIZ

ELSE

WRITE $(*, *)^{\prime}$ Vegetation is dying '

REMOB3 $=0.000001$

ENDIF

ENDIF

ELSE

REMOB3 $=0.000001$

ENDIF

*-----If the carbohydrates fill the rhizomes by TRANS1 from cohort1, REMOB1 stays zero; TRANS2

* remains zero, if the carbohydrates leave the rhizomes by REMOB3 to form the plants of cohort3,

* but also if no plant biomass of cohort2 is present. The plants of cohort2 are formed by REMOB3

* only at a certain DVS

IF (TRANS1 .GT. 0.0)REMOB1 $=0.0$

IF (DVS .GE. 2.0)REMOB1 $=0.0$ 
IF (DVS .GE. 2.0) TRANS1 $=0.0$

IF (DVS .GE. 2.3)TRANS2 $=0.0$

IF (REMOB3 .GT. 0.000001) TRANS3 $=0.0$

*-----Relative death rates

RDR = INSW (DVS-3.5001,0., LINT(RDRT,ILRDRT,DDTMP))

RDS = INSW (DVS-3.5001,0., LINT(RDST,ILRDST,DDTMP))

*.-.---Development rates

IF(DAVTMP .LT. 3.0) THEN

$\mathrm{DVR}=0.0$

ELSE IF (DVS.LE.1.) THEN

$\mathrm{DVR}=0.022 * \mathrm{DAVTMP} / 30$

ELSE IF (DVS.LE.6.0) THEN

$\mathrm{DVR}=0.015 * \mathrm{DAVTMP} / 30$

ENDIF

*-----ASTROOO

*-----Calculation of effective daytime temperature DTEFF $=$ AMAXI (0.,DAVTMP-TBASE $)$

*-----Calculation of dead plant material per organ

DLV3 $=$ TWLG3 $*$ RDR

DST3 $=$ TWSG3 $*$ RDR

$\mathrm{DRT} 3=\mathrm{TWRG} 3 * \mathrm{RDR}$

*-----Shoot photosynthesis at light saturation and daytime temperature effect on shoot photosynthesis AMAX $=$ AMAX1 $(0.00001$, AMX * AMTMP)

AMAX $=$ AMAX $*$ REDAM

AMTMP $=$ LINT(AMTMPT,ILAMTM,DDTMP)

*-----Before calling TOTASS, determine light extinction coefficients of plants $(\mathrm{K})$ and of water $(\mathrm{L})$

$\mathrm{L}=\mathrm{LINT}$ (LT,ILT,TIME)

$\mathrm{K}=\mathrm{LINT}(\mathrm{KT}, \mathrm{IKT}, \mathrm{DVS})$

*-----Daily total gross assimilation

CALL TOTASS

\$ (SC,DAYL,SINLD,COSLD,DSINBE,RDD,RC,L,K,AMAX,EE,

\$ TL,DEPTH,RCSHST,TGW,FGROS,FL,WLV,WST,

\$ DAY,HAR,HARDAY,HARDEP,DTGA,IRS)

*-----If harvesting takes place, weights various plant organs must be recalculated

* (TWLVG,TWSTG,TWRTG,TW)

IF(HAR .EQ. 1. AND. DAY .EQ. HARDAY) THEN

TWLG3 $=$ FLV $*$ TGW

TWSG3 $=$ FST $*$ TGW

TWRG3 $=$ FRT $*$ TGW

$\mathrm{TW}=\mathrm{TGW}+(\mathrm{TWLD} 1+\mathrm{TWSD} 1+\mathrm{TWRD} 1+\mathrm{TWLD} 2+\mathrm{TWSD} 2+\mathrm{TWRD} 2+\mathrm{TWLD} 3+\mathrm{TWSD} 3+\mathrm{TWRD} 3)$ ENDIF

*----Conversion assimilated $\mathrm{CO} 2$ to $\mathrm{CH} 2 \mathrm{O}$ $\mathrm{GPHOT}=\mathrm{DTGA} * 30 . / 44$.

*-----Induction of flowering at DVS=2.447; flowering occurs 10 days after induction 
* Induction of flowering, translocation and senescence occur simultaneously IF (DVS .GE. 2.447)THEN

IF ((TWLG3+TWSG3+TWRG3) .GT. 0.0)THEN

IF (TGW .GE. TWGRIZ) THEN

IF (TRANS2 .EQ. 0.0) THEN

TRANS3 $=$ CVT $*$ GPHOT $*($ TWLG3+TWSG3+TWRG3 $) /$

\$ (TWLG1+TWSG1+TWRG1+TWLG2+TWSG2+TWRG2+TWLG3+TWSG3+TWRG3))

$\$ *$ TRAFAC

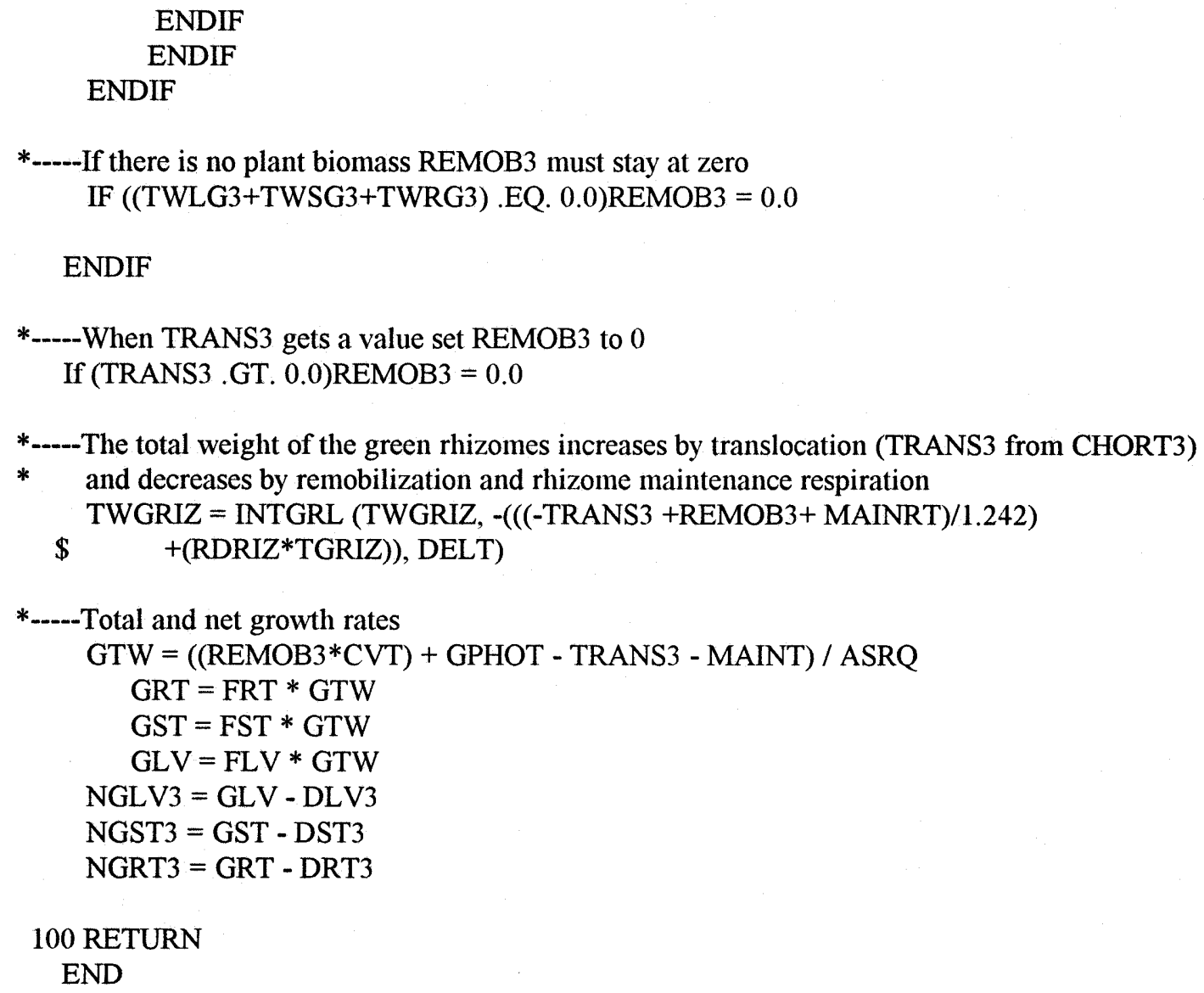




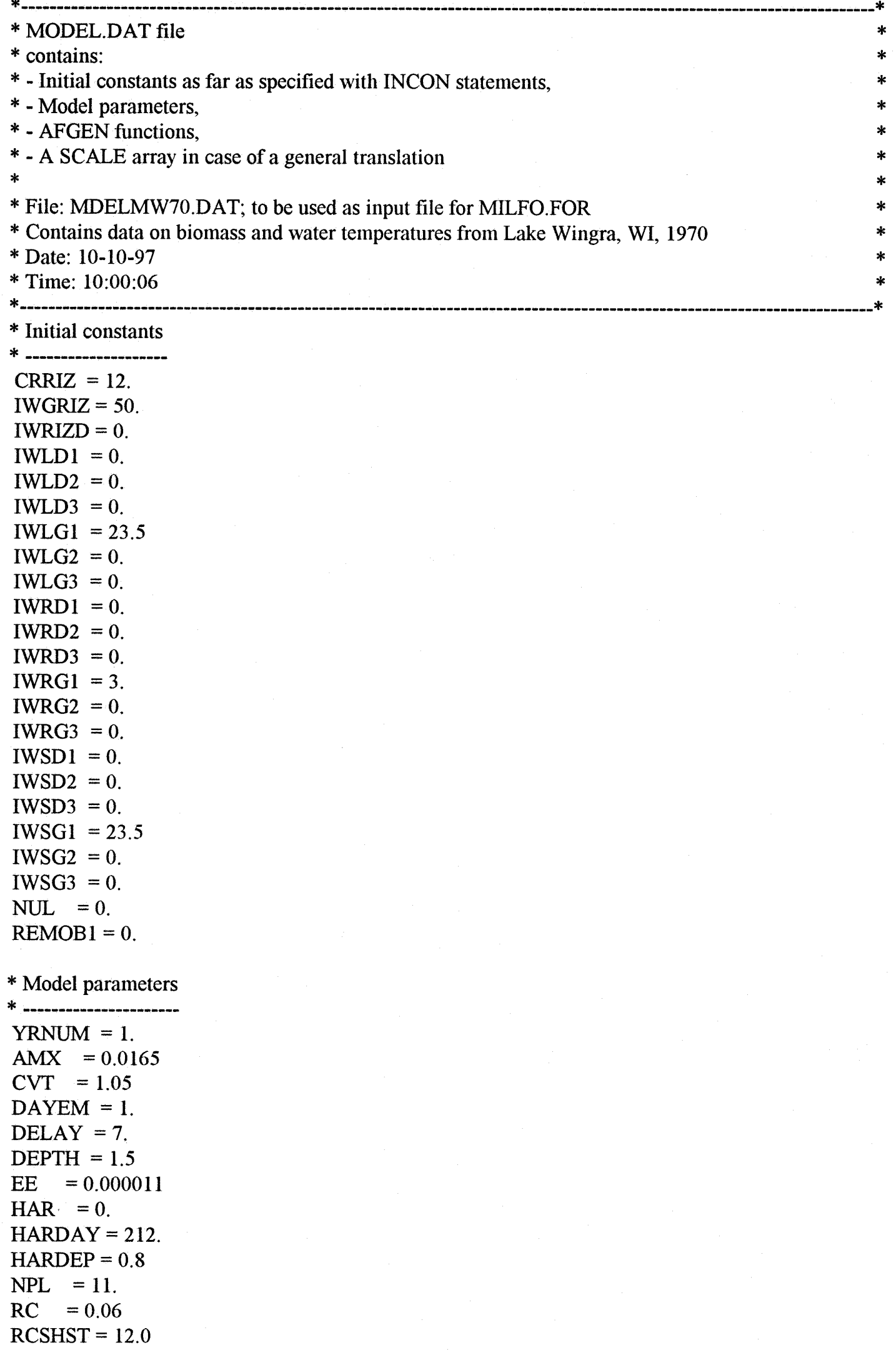




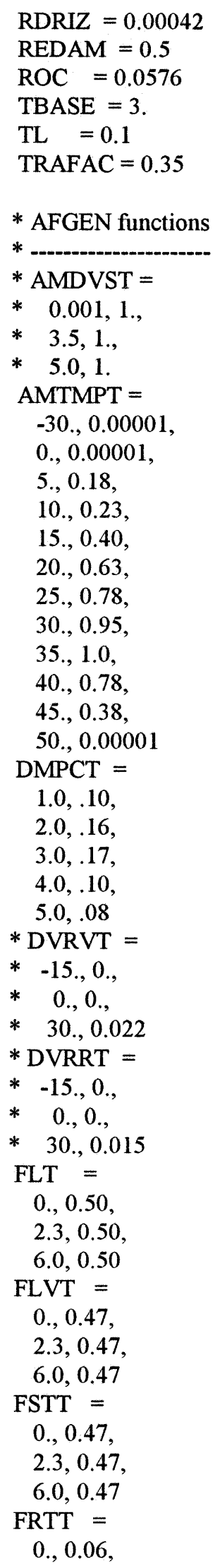




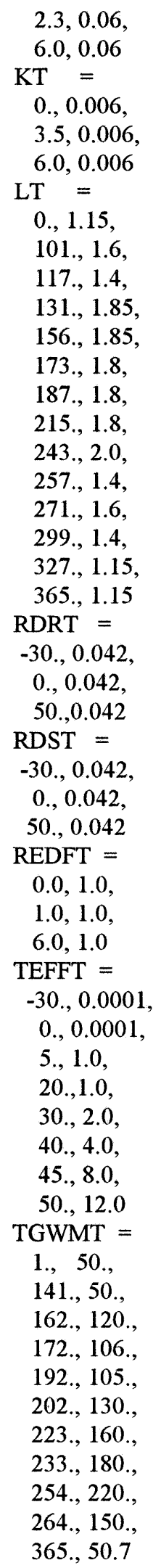


WTMPT $=$

1., 3.5,

60., 3.5,

100., 9.0,

150., 22.0,

190., 25.0,

220., 25.0,

250., 19.0,

300., 9.0,

340 ., 1.6,

365., 1.6 
$*$

* TIMER file contains

* - The used DRIVER and TRACE in case of GENERAL translation

* - The TIMER variables used in both translation modes

* - Additional TIMER variables in case of GENERAL translation

* - The WEATHER control variables if weather data are used

* - Miscellaneous FSE variables in case of FSE translation

* File: MILFO.FOR

* Date: $10-10-97$

* Time: 10:55:06

* TIMER variables used in GENERAL and FSE translation modes

$*$

$\begin{array}{ll}\text { STTIME }=1 . & \text { ! start time } \\ \text { FINTIM }=365 . & ! \text { finish time } \\ \text { DELT }=1 . & \text { ! time step (for Runge-Kutta first guess) } \\ \text { PRDEL }=1 . & \text { ! output time step } \\ \text { IPFORM }=4 & \quad ! \text { code for output table format: } \\ & ! 4=\text { spaces between columns } \\ & ! 5=\text { TAB's between columns (spreadsheet output) } \\ & ! 6=\text { two column output }\end{array}$

! The string array PRSEL contains the output variables for which ! formatted tables have to be made. One or more times there is a ! series of variable names terminated by the word $<$ TABLE $>$.

! The translator writes the variables in each PRINT statement to

PRSEL $=$ ! a separate table.

* 'DAVTMP',

* 'DAYL ',

* 'DDTMP',

* 'DTEFF',

* 'DTGA ',

* 'DVS ',

* 'FGROS ',

* 'GPHOT',

* 'IRS ',

* 'MAINRT',

* 'MAINT',

* 'REMOBl',

* 'REMOB2',

* 'REMOB3',

'TGW',

* 'TGWM',

* 'TMPSUM',

* 'TRANSI',

* 'TRANS2',

* 'TRANS3',

* 'TW ', 'TWGRIZ',

* 'TWLD1 ',

* 'TWLD2 ',

* 'TWLD3 ',

w imrrr $\mathrm{Ce}$ 


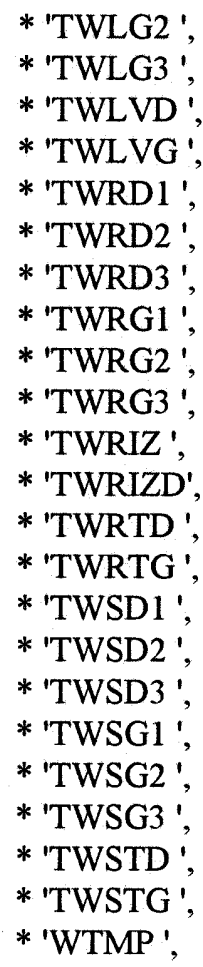

'<TABLE $>1$

COPINF $=$ 'N' ! Switch variable whether to copy the input files ! to the output file ('N' = do not copy,

! 'Y' = copy)

DELTMP = ' $\mathrm{N}$ ' ! Switch variable what should be done with the ! temporary output file ( $\mathrm{N}$ ' = do not delete, ! 'Y' = delete)

IFLAG $=1101 \quad$ ! Indicates where weather error and warnings ! go (1101 means errors and warnings to log ! file, errors to screen, see FSE manual)

${ }^{*} \mathrm{IOBSD}=1991,182$ ! List of observation data for which output is ! required. The list should consist of pairs ! <year $>$, <day $>$ combination
* WEATHER control variables
$*$
WTRDIR = 'C:ISYSIWEATHERI'
CNTR $=$ 'WIS' ! Country code
ISTN $=1$
IYEAR $=1970$
! Station code
! Year 
* CONTROL.DAT file contains:

* - File names to be used by FSE 2.1

* The input files (except FILEIR) may used in reruns

* Up to five input data files may be used (FILEIl-5)

*

$\begin{array}{ll}\text { FILEON }=\text { 'RES.DAT' } & \text { ! Normal output file } \\ \text { FILEOL }=\text { 'MODEL.LOG' } & \text { ! Log file } \\ \text { FILEIR }=\text { 'RERUNS.DAT' } & \text { ! Reruns file } \\ \text { FILEIT }=\text { 'TIMER.DAT' } & \text { ! File with timer data } \\ \text { FILEI }=\text { 'MODEL.DAT' } & \text { ! First input data file }\end{array}$

* FILEI2 $="$ " ! Second input data file (not used)

* FILEI3 $={ }^{\prime}$ ! ! Ihird input data file (not used)

* FILEI4 $="$ " ! Fourth input data file (not used)

* FILEI5 $="$ ! ! Fifth input data file (not used) 


\section{Appendix B Variable Listing}




\begin{tabular}{|c|c|c|}
\hline Abbreviation & Explanation & Dimension \\
\hline $\mathrm{AH}(\mathrm{i})$ & $\begin{array}{l}\text { Absolute height of vegetation on top of stratum I, } \\
\text { measured from the plant top }\end{array}$ & $\mathrm{m}$ \\
\hline AMAX & $\begin{array}{l}\text { Actual } \mathrm{CO}_{2} \text { assimilation rate at light saturation for } \\
\text { individual shoots }\end{array}$ & $\mathrm{g} \mathrm{CO}_{2} \cdot \mathrm{gDW}^{-1} \cdot \mathrm{h}^{-1}$ \\
\hline AMDVST & Developmental phase effect on AMX (relative) &,-- \\
\hline AMTMP & Daytime temperature effect on AMX (relative) & - \\
\hline AMTMPT & Table of AMX as function of DDTMP &,-- \\
\hline AMX & $\begin{array}{l}\text { Potential } \mathrm{CO}_{2} \text { assimilation rate at light saturation for } \\
\text { shoot tips }\end{array}$ & $\mathrm{g} \mathrm{CO}_{2} \cdot \mathrm{gDW}^{-1} \cdot \mathrm{h}^{-1}$ \\
\hline ASRQ & Assimilate requirement for plant dry matter production & $\mathrm{g} \mathrm{CH}_{2} \mathrm{O} . \mathrm{g} \mathrm{DW}^{-1}$ \\
\hline ATMTR & Atmospheric transmission coefficient & - \\
\hline COSLD & Intermediate variable in calculating solar height & - \\
\hline CRRIZ & Critical weight of the rhizome/root crown system & g DW. $\mathrm{m}^{-2}$ \\
\hline CVT & Conversion factor of translocated dry matter into $\mathrm{CH}_{2} \mathrm{O}$ & - \\
\hline DAVTMP & Daily average temperature & ${ }^{\circ} \mathrm{C}$ \\
\hline DAY & Day number (January $1=1$ ) & $d$ \\
\hline DAYEM & First Julian day number & $d$ \\
\hline DAYL & Day length & $\mathrm{h}$ \\
\hline DDELAY & Integer value of DELAY & - \\
\hline DDTMP & Daily average daytime temperature & ${ }^{\circ} \mathrm{C}$ \\
\hline DEC & Declination of the sun & radians \\
\hline DELAY & $\begin{array}{l}\text { Lag period chosen to relate water temperature to air } \\
\text { temp., in cases where water temp. has not been } \\
\text { measured }\end{array}$ & $d$ \\
\hline DEPTH & Water depth & $\mathrm{m}$ \\
\hline DLV & Death rate of leaves & $g$ DW. $m^{-2} \cdot d^{-1}$ \\
\hline DMPC(i) & Dry matter allocation to each plant layer (relative) & - \\
\hline DMPCT & Table of DMPC as function of water depth (relative) & - \\
\hline DSINB & Integral of SINB over the day & s.d ${ }^{-1}$ \\
\hline DSINBE & Daily total of effective solar height & s.d ${ }^{-1}$ \\
\hline DRT & Death rate of roots & g DW. $m^{-2} \cdot d^{-1}$ \\
\hline DSO & Daily extraterrestrial radiation & $J \cdot m^{-2} \cdot d^{-1}$ \\
\hline DST & Death rate of stems & g DW. $\mathrm{m}^{-2} \cdot \mathrm{d}^{-1}$ \\
\hline DTEFF & Daily effective temperature & ${ }^{\circ} \mathrm{C}$ \\
\hline DTGA & Daily total gross $\mathrm{CO}_{2}$ assimilation of the plant & $\mathrm{g} \mathrm{CO}_{2} \cdot \mathrm{m}^{-2} \cdot \mathrm{d}^{-1}$ \\
\hline
\end{tabular}




\begin{tabular}{|c|c|c|}
\hline Abbreviation & Explanation & Dimension \\
\hline DTR & Measured daily total global radiation & $J \cdot m^{-2} \cdot d^{-1}$ \\
\hline DVR & $\begin{array}{l}\text { Development rate as function of daily average } \\
\text { temperature sum }\end{array}$ & $\mathrm{d}^{-1},{ }^{\circ} \mathrm{C}$ \\
\hline DVRRT & $\begin{array}{l}\text { Table of postanthesis development rate as function of } \\
\text { daily average temperature sum (used for calibration; } \\
\text { not read from MODEL.DAT) }\end{array}$ & $\mathrm{d}^{-1},{ }^{\circ} \mathrm{C}$ \\
\hline DVRVT & $\begin{array}{l}\text { Table of preanthesis development rate as function of } \\
\text { daily average temperature sum (used for calibration; } \\
\text { not read from MODEL.DAT) }\end{array}$ & $\mathrm{d}^{-1},{ }^{\circ} \mathrm{C}$ \\
\hline DVS & Development phase of the plant & - \\
\hline EE & Initial light-use efficiency for shoots & $\mathrm{g} \mathrm{CO}_{2} \cdot \mathrm{J}^{-1}$ \\
\hline FGROS & Instantaneous $\mathrm{CO}_{2}$ assimilation rate of the plant & $\mathrm{g} \mathrm{CO}_{2} \cdot \mathrm{m}^{-2} \cdot \mathrm{h}^{-1}$ \\
\hline FGL & Instantaneous $\mathrm{CO}_{2}$ assimilation rate per depth layer & $\mathrm{g} \mathrm{CO}_{2} \cdot \mathrm{m}^{-2} \cdot \mathrm{h}^{-1}$ \\
\hline $\mathrm{FL}$ & $\begin{array}{l}\text { Leaf dry matter allocation to each layer of the plant } \\
\text { (relative) }\end{array}$ & - \\
\hline FLT & Table to read FL as function of DVS &,-- \\
\hline FLV & Fraction of total dry matter increase allocated to leaves & - \\
\hline FLVT & Table to read FLV as function of DVS & - \\
\hline FRDIF & Diffuse radiation as a fraction of total solar radiation & - \\
\hline FRT & Fraction of total dry matter increase allocated to roots & - \\
\hline FRTT & Table to read FRT as function of DVS &,-- \\
\hline FST & Fraction of total dry matter increase allocated to stems & - \\
\hline FSTT & Table to read FST as function of DVS &,-- \\
\hline GLV & Dry matter growth rate of leaves & g DW. $m^{-2} \cdot d^{-1}$ \\
\hline GPHOT & Daily total gross assimilation rate of the community & $\mathrm{g} \mathrm{CH}_{2} \mathrm{O} \cdot \mathrm{m}^{-2} \cdot \mathrm{d}^{-1}$ \\
\hline GRT & Dry matter growth rate of roots & g DW. $m^{-2} \cdot d^{-1}$ \\
\hline GST & Dry matter growth rate of stems & g DW. $m^{-2} \cdot d^{-1}$ \\
\hline GTW & $\begin{array}{l}\text { Dry matter growth rate of vegetation (plant excluding } \\
\text { rhizome/root crown system) }\end{array}$ & g DW. $m^{-2} \cdot d^{-1}$ \\
\hline HAR & Harvesting ( $0=$ no harvesting, $1=$ harvesting) & - \\
\hline HARDAY & Harvesting day number & $d$ \\
\hline HARDEP & Harvesting depth (measured from water surface) & $\mathrm{m}$ \\
\hline$H I G(i)$ & $\begin{array}{l}\text { Height on top of stratum I (measured from water } \\
\text { surface) }\end{array}$ & $\mathrm{m}$ \\
\hline HOUR & Selected hour during the day & $\mathrm{h}$ \\
\hline I & Counter in DO LOOP & - \\
\hline IABS(i) & Total irradiance absorbed per plant layer & J.m $\mathrm{m}^{-2} \cdot \mathrm{s}^{-1}$ \\
\hline
\end{tabular}




\begin{tabular}{|c|c|c|}
\hline Abbreviation & Explanation & Dimension \\
\hline IABSL(i) & Total irradiance absorbed by plant shoots & $J \cdot m^{-2} \cdot s^{-1}$ \\
\hline IDAY & Integer equivalent of variable DAY & $d$ \\
\hline IRS & Total irradiance just under the water surface & $J \cdot m^{-2} \cdot s^{-1}$ \\
\hline $\operatorname{IRZ}(\mathrm{i})$ & Total irradiance on top of depth layer I & $J \cdot m^{-2} \cdot s^{-1}$ \\
\hline IWGRIZ & Initial weight of live rhizome/root crown system & $\mathrm{g} D W \cdot \mathrm{m}^{-2}$ \\
\hline IWLD1,2,3 & Initial dry matter of dead leaves cohort $1,2,3$ & $\mathrm{~g} \mathrm{DW} \cdot \mathrm{m}^{-2}$ \\
\hline IWLG1,2,3 & Initial dry matter of green (live) leaves cohort $1,2,3$ & g DW. $\mathrm{m}^{-2}$ \\
\hline IWRIZD & Initial weight of dead rhizome/root crown system & $\mathrm{g} \mathrm{DW} \cdot \mathrm{m}^{-2}$ \\
\hline IWRD1,2,3 & Initial dry matter of dead roots cohort $1,2,3$ & $\mathrm{~g} D W \cdot \mathrm{m}^{-2}$ \\
\hline IWRG1,2,3 & Initial dry matter of green (live) roots cohort $1,2,3$ & $\mathrm{~g} D W \cdot \mathrm{m}^{-2}$ \\
\hline IWSD1,2,3 & Initial dry matter of dead stems cohort $1,2,3$ & $\mathrm{~g}$ DW.m. $\mathrm{m}^{-2}$ \\
\hline IWSG1,2,3 & Initial dry matter of green (live) stems cohort $1,2,3$ & g DW. $\mathrm{m}^{-2}$ \\
\hline K & Plant species specific light-extinction coefficient & $\mathrm{m}^{2} \cdot \mathrm{g} \mathrm{DW}^{-1}$ \\
\hline KT & Table to read $\mathrm{K}$ as function of DVS & $\mathrm{m}^{2} \cdot \mathrm{g} \mathrm{DW}^{-1},-$ \\
\hline L & Water type specific light-extinction coefficient & $m^{-1}$ \\
\hline LAT & Latitude of the site & degrees \\
\hline LT & Table to read $L$ as function of day number & $m^{-1}, d$ \\
\hline MAINT & Maintenance respiration rate of the plant & $\mathrm{g} \mathrm{CH}_{2} \mathrm{O} \cdot \mathrm{m}^{-2} \cdot \mathrm{d}^{-1}$ \\
\hline MAINRT & $\begin{array}{l}\text { Maintenance respiration rate of the rhizome/root crown } \\
\text { system }\end{array}$ & $\mathrm{g} \mathrm{CH}_{2} \mathrm{O} \cdot \mathrm{m}^{-2} \mathrm{~d}^{-1}$ \\
\hline MAINTS & $\begin{array}{l}\text { Maintenance respiration rate of the plant at reference } \\
\text { temperature }\end{array}$ & $\mathrm{g} \mathrm{CH}_{2} \mathrm{O} \cdot \mathrm{m}^{-2} \mathrm{~d}^{-1}$ \\
\hline NGLV & Net growth rate of leaves & $\mathrm{g} \mathrm{DW} \cdot \mathrm{m}^{-2} \cdot \mathrm{d}^{-1}$ \\
\hline NGRT & Net growth rate of roots & g DW. $m^{-2} \cdot d^{-1}$ \\
\hline NGST & Net growth rate of stems & g DW. $m^{-2} \cdot d^{-1}$ \\
\hline NPL & Plant density & plants.$m^{-2}$ \\
\hline NUL & Zero (0) & - \\
\hline PAR & $\begin{array}{l}\text { Instantaneous flux of photosynthetically active } \\
\text { radiation }\end{array}$ & $J \cdot m^{-2} \cdot s^{-1}$ \\
\hline PARDIF & Instantaneous flux of diffuse PAR & $J \cdot m^{-2} \cdot s^{-1}$ \\
\hline PARDIR & Instantaneous flux of direct PAR & $\mathrm{J} \cdot \mathrm{m}^{-2} \cdot \mathrm{s}^{-1}$ \\
\hline $\mathrm{PI}$ & Ratio of circumference to diameter of circle & - \\
\hline RAD & Factor to convert degrees to radians & radians.degree $e^{-1}$ \\
\hline
\end{tabular}




\begin{tabular}{|c|c|c|}
\hline Abbreviation & Explanation & Dimension \\
\hline $\mathrm{RC}$ & $\begin{array}{l}\text { Reflection coefficient of irradiation at water surface } \\
\text { (relative) }\end{array}$ & - \\
\hline RCSHST & $\begin{array}{l}\text { Relation coefficient rhizome/root crown weight-stem } \\
\text { length }\end{array}$ & m. g DW ${ }^{-1}$ \\
\hline RDR & Relative death rate of leaves (on DW basis) & $d^{-1}$ \\
\hline RDRIZ & $\begin{array}{l}\text { Relative death rate of rhizome/root crown system (on } \\
\text { DW basis) }\end{array}$ & $d^{-1}$ \\
\hline RDRT & Table to read RDR as function of DAVTMP & $\mathrm{d}^{-1},{ }^{\circ} \mathrm{C}$ \\
\hline RDS & Relative death rate of stems and roots (on DW basis) & $d^{-1}$ \\
\hline RDST & Table to read RDS as function of DAVTMP & $\mathrm{d}^{-1},{ }^{\circ} \mathrm{C}$ \\
\hline REDAM & $\begin{array}{l}\text { Reduction factor to relate AMX to } \mathrm{pH} \text { and oxygen } \\
\text { levels of the water as function of DVS (relative) }\end{array}$ & - \\
\hline REDF(i) & $\begin{array}{l}\text { Reduction factor for AMX to account for senescence } \\
\text { plant parts over vertical axis of vegetation (relative) }\end{array}$ & - \\
\hline REDFT & $\begin{array}{l}\text { Table to read factor to reduce AMX over vertical axis of } \\
\text { vegetation (relative) }\end{array}$ & - \\
\hline REMOB1,2,3 & Remobilization rate of carbohydrates cohort $1,2,3$ & $\mathrm{~g} \mathrm{CH}_{2} \mathrm{O} \cdot \mathrm{m}^{-2} \cdot \mathrm{d}^{-1}$ \\
\hline ROC & $\begin{array}{l}\text { Relative conversion rate of rhizome/root crown into } \\
\text { plant material }\end{array}$ & $\mathrm{gCH}_{2} \mathrm{O} \cdot \mathrm{gDW}^{-1} \cdot \mathrm{d}^{-1}$ \\
\hline SC & Solar constant corrected for varying distance sun-earth & $J \cdot m^{-2} \cdot s^{-1}$ \\
\hline $\mathrm{SC}(\mathrm{i})$ & Standing crop in depth layer I & g DW. $m^{-2}$.layer ${ }^{-1}$ \\
\hline SINB & Sine of solar elevation & - \\
\hline SINLD & Intermediate variable in calculating solar declination & - \\
\hline STEMLE & Stem length & $\mathrm{m}$ \\
\hline TBASE & Base temperature for juvenile plant growth & ${ }^{\circ} \mathrm{C}$ \\
\hline TEFF & $\begin{array}{l}\text { Factor accounting for effect of daily average daytime } \\
\text { temperature on maintenance respiration }\end{array}$ & - \\
\hline TEFFT & Table to read TEFF as function of DDTMP &,$-{ }^{\circ} \mathrm{C}$ \\
\hline TGRIZ & $\begin{array}{l}\text { Total live rhizome/root crown system weight of the } \\
\text { previous day }\end{array}$ & g DW.m-2 \\
\hline TGW & $\begin{array}{l}\text { Total live plant dry weight (excluding rhizome/root } \\
\text { crown system) }\end{array}$ & g DW.m. ${ }^{-2}$ \\
\hline TGWM & Total live plant dry weight measured (field site) & $\mathrm{g} \mathrm{DW} \cdot \mathrm{m}^{-2}$ \\
\hline TGWMT & Table to read TGWM as function of day number & g DW. $m^{-2}, d$ \\
\hline TL & Thickness each plant layer & $\mathrm{m}$ \\
\hline TMAX & Daily maximum temperature & ${ }^{\circ} \mathrm{C}$ \\
\hline TMIN & Daily minimum temperature & ${ }^{\circ} \mathrm{C}$ \\
\hline TMPSUM & Temperature sum after 1 January & ${ }^{\circ} \mathrm{C}$ \\
\hline
\end{tabular}




\begin{tabular}{|c|c|c|}
\hline Abbreviation & Explanation & Dimension \\
\hline TRAFAC & Translocation factor (relative) & - \\
\hline TRANS1,2,3 & Translocation rate of carbohydrates cohort $1,2,3$ & $\mathrm{~g} \mathrm{CH} \mathrm{CH}_{2} \mathrm{O} \cdot \mathrm{m}^{-2} \cdot \mathrm{d}^{-1}$ \\
\hline TREMOB & Total remobilization & $\mathrm{g} \mathrm{CH}_{2} \mathrm{O} \cdot \mathrm{m}^{-2}$ \\
\hline TW & $\begin{array}{l}\text { Total live + dead plant dry weight (excluding } \\
\text { rhizome/root crown system) }\end{array}$ & $g$ DW. $m^{-2}$ \\
\hline TWGRIZ & $\begin{array}{l}\text { Total live rhizome/root crown dry weight of the current } \\
\text { day }\end{array}$ & $\mathrm{g} \mathrm{DW} \cdot \mathrm{m}^{-2}$ \\
\hline TWLD1,2,3 & Total dead leaf dry weight cohort $1,2,3$ & $\mathrm{~g} \mathrm{DW} \cdot \mathrm{m}^{-2}$ \\
\hline TWLG1,2,3 & Total live leaf dry weight cohort $1,2,3$ & $g$ DW. $m^{-2}$ \\
\hline TWLVD & Total dry weight of dead leaves 2 or 3 cohorts & $\mathrm{g} D W \cdot \mathrm{m}^{-2}$ \\
\hline TWLVG & Total dry weight of live leaves 2 or 3 cohorts & $\mathrm{g} D W \cdot \mathrm{m}^{-2}$ \\
\hline TWRD1,2,3 & Total dead root dry weight cohort $1,2,3$ & $g$ DW. $m^{-2}$ \\
\hline TWRG1,2,3 & Total live root dry weight cohort $1,2,3$ & $\mathrm{~g} \mathrm{DW} \cdot \mathrm{m}^{-2}$ \\
\hline TWRIZ & Total live + dead rhizome/root crown system weight & $\mathrm{g} \mathrm{DW} \cdot \mathrm{m}^{-2}$ \\
\hline TWRIZD & Total dead rhizome/root crown system weight & $\mathrm{g} D W \cdot \mathrm{m}^{-2}$ \\
\hline TWRTD & Total dry weight of dead roots 2 or 3 cohorts & $g$ DW. $m^{-2}$ \\
\hline TWRTG & Total dry weight of live roots 2 or 3 cohorts & $\mathrm{g} \mathrm{DW} \cdot \mathrm{m}^{-2}$ \\
\hline TWSD1,2,3 & Total dry weight of dead stems 2 or 3 cohorts & $\mathrm{g} \mathrm{DW} \cdot \mathrm{m}^{-2}$ \\
\hline TWSG1,2,3 & Total live stem dry weight cohort $1,2,3$ & $\mathrm{~g} D W \cdot \mathrm{m}^{-2}$ \\
\hline TWSTD & Total dry weight of dead stems 2 or 3 cohorts & $\mathrm{g} D W \cdot \mathrm{m}^{-2}$ \\
\hline TWSTG & Total dry weight of live stems 2 or 3 cohorts & $\mathrm{g} D W \cdot \mathrm{m}^{-2}$ \\
\hline WLV & Dry weight of leaves (live + dead) & $\mathrm{g} D W \cdot \mathrm{m}^{-2}$ \\
\hline WRT & Dry weight of roots (live + dead) & $\mathrm{g} \mathrm{DW} \cdot \mathrm{m}^{-2}$ \\
\hline WST & Dry weight of stems (live + dead) & $\mathrm{g} D W \cdot \mathrm{m}^{-2}$ \\
\hline WTMP & Daily water temperature & ${ }^{\circ} \mathrm{C}$ \\
\hline WTMPT & Table to read WTMP as function of day number & ${ }^{\circ} \mathrm{C}, \mathrm{d}$ \\
\hline YRNUM & Year number simulation (1-5) & Y \\
\hline
\end{tabular}




\section{Appendix C Manipulation of Literature Data Used for the Model Equations}

\section{Photosynthesis}

\section{Effect of daytime temperature on photosynthesis (AMTMP)}

To calibrate the relationship between temperature and photosynthetic activity, the photosynthetic rates compared with the photosynthetic rate at $35^{\circ} \mathrm{C}$ published by Titus and Adams (1979a,b) were used. ${ }^{1}$

\begin{tabular}{||l|l||}
\hline \begin{tabular}{|l||} 
Table C1 \\
Relative Photosynthetic Activity of Milfoil Shoots in Response to \\
Temperature (Conditions were light saturating and water was in \\
equilibrium with atmospheric CO $_{2}$ )
\end{tabular} \\
\hline \hline Temperature, ${ }^{\circ}$ C & Relative Photosynthetic Rate \\
\hline \hline 0 & 0.00001 \\
\hline 5 & 0.18 \\
\hline 10 & 0.23 \\
\hline 15 & 0.40 \\
\hline 20 & 0.63 \\
\hline 25 & 0.78 \\
\hline 30 & 0.95 \\
\hline 35 & 1.00 \\
\hline 40 & 0.78 \\
\hline 45 & 0.38 \\
\hline 50 & 0.05 \\
\hline 55 & 0.00001 \\
\hline
\end{tabular}

\footnotetext{
1 References cited in this appendix are located at the end of the main text.
} 


\section{Growth}

\section{Assimilate requirement for dry matter production (ASRQ)}

The value of the conversion factor for growth of plant biomass, weighted according to its composition, can be computed in a simple way from the fractions of nonstructural carbohydrates, proteins, fats, cellulose, organic acids, and minerals (Table C2). This conversion factor indicates the amount of glucose consumed to produce each $\mathrm{g}$ of plant biomass $\left(\mathrm{g} \mathrm{CH}_{2} \mathrm{O} \mathrm{g} \mathrm{DW}^{-1}\right)$. This method has been employed to calculate assimilate requirement of milfoil shoots for biomass production.

\begin{tabular}{|c|c|c|}
\hline \multicolumn{3}{|c|}{$\begin{array}{l}\text { Table C2 } \\
\text { Estimated Chemical Composition of Milfoil Shoots (this study) and } \\
\text { Typical Conversion Efficiencies for Agricultural Crops Showing } \\
\text { How Much Glucose is Used for the Synthesis of Each Organic } \\
\text { Matter Component (Penning de Vries and Van Laar 1982b) }\end{array}$} \\
\hline Component & $\begin{array}{l}\text { Contribution to Biomass } \\
\text { percent }\end{array}$ & $\begin{array}{l}\text { Conversion Factor } \\
\mathrm{g} \mathrm{CH}_{2} \mathrm{Og} \mathrm{DW}^{-1}\end{array}$ \\
\hline Nonstructural carbohydrates & 14 & 1.242 \\
\hline Proteins & 17 & 1.704 \\
\hline Fats & 8 & 3.106 \\
\hline Cellulose & 33 & 2.174 \\
\hline Organic acids & 11.2 & 0.929 \\
\hline Minerals & 16.8 & 0.050 \\
\hline Milfoil shoot & 100 & 1.539 \\
\hline
\end{tabular}

\section{Site-Specific Environmental Conditions}

\section{$\mathrm{pH}$, alkalinity, and trophic state}

$\mathrm{pH}$, alkalinity, and trophic state are important factors influencing primary production in aquatic systems. $\mathrm{pH}$ and alkalinity determine carbon availability for photosynthesis, and trophic state gives an indication of algal production and consequent light attenuation within the water column. The model is calibrated for dissolved inorganic carbon concentrations 1.1-1.8 mmol (alkalinity Lake Wingra 1.1-1.8 mmol; Lee and Kluesener 1972). pH affecting potential photosynthetic rate at light saturation through REDAM can be modified by the user. 
The model is calibrated for a light-extinction coefficient range of the water of $1.15-2.0 \mathrm{~m}^{-1}$ (Lee and Kluesener 1972); the value of this parameter (L) can be modified by the user.

\section{Water temperature}

The temperature has been measured in the surface water of Lake Wingra at several points in time in $1970 .{ }^{1}$ For Days 1 and 365, the same temperatures as those measured on the nearest dates in Lake Wingra, Wisconsin, have been taken.

\begin{tabular}{|c|c|c|c|}
\hline \multicolumn{4}{|c|}{$\begin{array}{l}\text { Table C3 } \\
\text { Seasonally Measured Daytime Temperatures in the Surface Water } \\
\text { of Lake Wingra, Wisconsin, during } 1970\end{array}$} \\
\hline Day, number & Temperature, ${ }^{\circ} \mathrm{C}$ & Day, number & Temperature, ${ }^{\circ} \mathrm{C}$ \\
\hline 1 & 3.5 & 216 & 25.3 \\
\hline 62 & 3.5 & 223 & 25.3 \\
\hline 69 & 4.0 & 230 & 24.4 \\
\hline 76 & 5.3 & 237 & 23.2 \\
\hline 84 & 6.3 & 244 & 22.5 \\
\hline 90 & 6.5 & 246 & 22.9 \\
\hline 97 & 5.7 & 251 & 23.0 \\
\hline 98 & 7.0 & 258 & 16.5 \\
\hline 104 & 6.7 & 265 & 20.0 \\
\hline 111 & 6.9 & 272 & 15.8 \\
\hline 118 & 15.2 & 278 & 15.1 \\
\hline 125 & 15.3 & 286 & 14.3 \\
\hline 132 & 17.6 & 293 & 11.8 \\
\hline 139 & 17.0 & 300 & 12.8 \\
\hline 146 & 19.1 & 307 & 8.2 \\
\hline 153 & 19.1 & 321 & 4.1 \\
\hline 160 & 22.7 & 328 & 0.3 \\
\hline 167 & 23.9 & 335 & 1.7 \\
\hline 174 & 22.7 & 342 & 0.9 \\
\hline 181 & 24.8 & 349 & 0.1 \\
\hline 188 & 23.5 & 355 & 1.2 \\
\hline 195 & 26.8 & 363 & 1.6 \\
\hline 202 & 22.4 & 365 & 1.6 \\
\hline 209 & 26.7 & & \\
\hline
\end{tabular}

${ }^{1}$ Personal Communication, 1995, J. E. Titus, Univeristy of Binghamton, New York. 


\section{REPORT DOCUMENTATION PAGE}

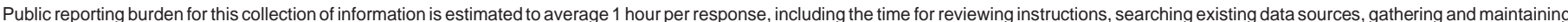
the data needed, and completing and reviewing the collection of information. Send comments regarding this burden estimate or any other aspect of this collection of information, including suggestions

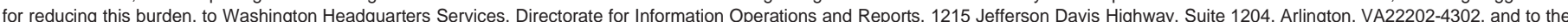
Office of Management and Budget, Paperwork Reduction Project (0704-0188), Washington, DC20503.

\begin{tabular}{|l|l|l|l|}
\hline 1.AGENCY USE ONLY (Leave blank) & $\begin{array}{c}\text { 2.REPORT DATE } \\
\text { September } 1999\end{array}$ & \multicolumn{2}{|l|}{$\begin{array}{l}\text { 3.REPORT TYPE AND DATES COVERED } \\
\text { Final report }\end{array}$} \\
\hline 4.TIT
\end{tabular}

4.TITLE AND SUBTITLE

A Simulation Model for Growth of the Submersed Aquatic Macrophyte

Eurasian Watermilfoil (Myriophyllum spicatum L.)

6.AUTHOR(S)

Elly P. H. Best, William A. Boyd

7.PERFORMING ORGANIZATION NAME(S) AND ADDRESS(ES)

U.S. Army Engineer Research and Development Center

Waterways Experiment Station

3909 Halls Ferry Road

5.FUNDING NUMBERS

Vicksburg, MS 39180-6199

9.SPONSORING/MONITORING AGENCY NAME(S) AND ADDRESS(ES)

U.S. Army Corps of Engineers

Washington, DC 20314-1000

8.PERFORMING ORGANIZATION REPORT NUMBER

Technical Report A-99-3

\section{SUPPLEMENTARY NOTES}

Available from National Technical Information Service, 5285 Port Royal Road, Springfield, VA 22161.

12a.DISTRIBUTION/AVAILABILITY STATEMENT

12b.DISTRIBUTION CODE

Approved for public release; distribution is unlimited.

13.ABSTRACT (Maximum 200 words)

A simulation model for biomass dynamics of the submersed macrophyte Myriophyllum spicatum is presented. The model (MILFO) is based on carbon flow through the vegetation in meter-squared $\left(\mathrm{m}^{2}\right)$ water columns. It includes descriptions of several factors that affect biomass dynamics, such as site-characteristic changes in climate, water temperature, water transparency, $\mathrm{pH}$ and oxygen effects on $\mathrm{CO}_{2}$ assimilation rate at light saturation, wintering strategies, grazing and mechanical control (removal of shoot biomass), and of latitude. The characteristics of the community and of the site can be easily modified by the user.

MILFO incorporates insights into the processes affecting the dynamics of an Eurasian watermilfoil community in relatively shallow, hard water (0.5-6 $\mathrm{m}$ depth; DIC concentration > $0.8 \mathrm{mmol}$ and $\mathrm{pH}$ ranging from 7.6 to 9.4) under ample supply of nitrogen and phosphorus in a pest-, disease-, and competitor-free environment under the prevailing weather conditions. It has been calibrated on data pertaining to a milfoil community in Lake Wingra, Wisconsin, USA. At that site, growth starts from the basal rhizome/root crown system, alone or with wintering shoot biomass present. Shoot biomass usually peaks twice a year, in June originating from the first plant cohort and in August from the second cohort, and intensive

\section{SUBJECT TERMS}

Biomass dynamics

Carbon flow

Myriophyllum spicatum

(Continued)

Plant cohorts

Plant growth

Simulation model
15.NUMBER OF PAGES

111

16.PRICE CODE

\section{LIMITATION OF ABSTRACT}

8.SECURITY CLASSIFICATION OF THIS PAGE

UNCLASSIFIED
19.SECURITY CLASSIFICATION OF ABSTRACT OF REPORT

UNCLASSIFIED

NSN 7540-01-280-5500
Standard Form 298 (Rev. 2-89)

Prescribed by ANSI Std. Z39-18 298-102 


\section{3. (Concluded).}

downward transport of soluble carbohydrates occurs after anthesis of each cohort, replenishing the rhizome/root crown system. In a tropical climate, a third plant cohort is active.

MILFO simulated the dynamics of plant and rhizome/root crown biomass at Lake Wingra well over a period of 1 to 5 years. It has been used to calculate plant and rhizome/root crown biomass for the same latitude in a different year and for other latitudes in temperature (Alabama, USA) and tropical (India) areas, where it simulated biomass ranges similar to those measured in the field.

Sensitivity analysis showed that maximum plant biomass of a Eurasian watermilfoil community is most sensitive to a change in photosynthetic activity at light saturation and very sensitive to a change in light-use efficiency, and that end-of-year rhizome/root crown biomass was often more sensitive than maximum plant biomass. The latter illustrates the utmost importance of the rhizome/root crown system for local survival and biomass production in milfoil.

Environmental factor analysis indicated that changes in climate can greatly affect simulated end-of-year rhizome/root crown biomass. Maximum plant biomass proved far more sensitive to changes in water transparency than to changes in water depth.

The model can be used as a tool to predict the dynamics of a Eurasian watermilfoil community over 1- to 5-year periods. Running the model with different parameter values specific for any particular site and/or treatment, for example, biomass removal to a certain water depth, helps in gaining insight into the predominant mechanisms regulating submersed plant dynamics. 
Destroy this report when no longer needed. Do not return it to the originator. 